\title{
MOBILIZATION AND REDISTRIBUTION OF PHOSPHATE AND RARE EARTH ELEMENTS IN THE WEATHERING ZONE ABOVE PANDA HILL CARBONATITE, SW TANZANIA
}

\section{BY}

\section{FAUSTINA MGONDE}

\author{
A Thesis submitted to \\ the Faculty of Graduate studies and Research \\ in partial fulfilment of \\ the requirements for the degree of \\ Master of Science
}

Ottawa-Carleton Geoscience Centre

Department of Earth Sciences

Carleton University

Ottawa, Ontario

CANADA

Dec.1994

@ Copyright

1994, Faustina Mgonde 


\begin{abstract}
Petrographic and geochemical studies of a $12 \mathrm{~m}$ deep weathering profile above the Cretaceous Panda Hill carbonatite, southwest Tanzania, indicate that leaching of calcite from the primary carbonatite has led to the accumulation of apatite in the saprolite zone. $\mathrm{Ba}, \mathrm{Sr}$ and $\mathrm{REEs}$ from the carbonatite, and $\mathrm{Al}, \mathrm{Fe}$ and $\mathrm{Si}$ from country rocks have been transported by groundwater and redeposited in secondary phosphates, Fe oxides, and secondary quartz.

Most of the phosphate at Panda Hill is contained in apatite. Alteration of apatite has enabled $\mathrm{Ba}, \mathrm{Sr}$ and the REEs to substitute for $\mathrm{Ca}$, and $\mathrm{SO}_{4}$ for $\mathrm{PO}_{4}$ in the apatite structure. Such substitutions, along with the addition of $\mathrm{Al}$, have led to the formation of goyazite and svanbergite. Rhabdophane was also identified. All of these minerals are concentrated in the saprolite zone. Synchysite was identified in the carbonatite.
\end{abstract}




\section{ACKNOWLEDGEMENTS}

I thank my supervisors, Dr.Kenneth Torrance and Dr.Keith Bell for their continuous support and encouragement during the entire period of my program. I appreciate the time they took to critically review and improve this manuscript, and their willingness to provide guidance whenever I needed it.

I am grateful to Dr.D.Hogarth for providing me with information on the mineralogy of carbonatites, and Dr.Tony Simonetti for his advice and help when reviewing the section on geochemistry.

I wish to thank all who helped in the preparation of samples for analysis, and the analysts who turned in various analytical data for my samples, although the samples were very "strange" to them. Thin sections were prepared by John Everest and Anett Briggs, while John Stevenson helped me get acquainted with the jaw crusher and shatter box.

Dr.Simon Jackson of Memorial University not only provided data on the REE geochemistry, but also some detailed information about the nature of the problems encountered during analysis of the samples, and the possible causes. Peter Jones did overtime work with the SEM and turned in sufficient data despite the chaotic nature of the mineralogy, which required repetitions. Ron Hatree did the XRF analyses and produced data in time. Ron Conlon produced XRD patterns.

Fellow graduate students in the Earth Sciences and Geography departments provided much professional and moral support during my time at Carleton, for which I am very grateful.

Funding for this research was provided by the Government of Canada through CIDA. I am very grateful to CIDA for providing funds for my field work in Tanzania and for their support throughout the program. I also thank the Ministry of Water, Energy and Minerals in Tanzania for allowing me to pursue further studies, and for their support during my field work. 
Acceptance Sheet

ii

Abstract

Acknowledgements

iii

Table of contents

iv

List of Tables

List of Figures

List of Plates

Panda Hill

vii

viii

ix

$\mathrm{x}$

CHAPTER 1 - Introduction

1.1 Background information

1

1.2 Location and accessibility

1.3 Previous work

1.3.1 Panda Hill as a niobium resource

1.3.2 Panda Hill as a phosphate resource

CHAPTER 2 - Geological setting of Panda

Hill carbonatite

2.1 Geology

2.1.1 Regional geology

10

2.1.2 Geology of Panda Hill complex

2.1.3 Mineralogy

14

16

2.2 Panda Hill phosphate rock

CHAPTER 3 - Phosphate rock

3.1 Background information

3.2 Genesis and geological setting of phosphate rock

3.3 Classification of phosphate rock

3.4 Weathering of carbonatites

3.4.1 Introduction

3.4.2 Supergene formation of phosphate rock

3.4.3 Mobilization and redistribution of REE during weathering

CHAPTER 4 - Field work

4.1 Introduction

4.2 Field results

4.2.1 Profile over carbonatite 
4.2.2 Profile over apatite-magnetite rock 36

4.2.3 Profile over fenite 37

CHAPTER 5 - Weathering of Panda Hill carbonatite

5.1 Introduction

38

5.2 Optical microscopy 40

5.2.1 General description of samples $\quad 40$

5.2.2 Petrographic observations 41

5.2.2.1 Carbonatite 41

2.2.1 Residual materials $\quad 44$

5.2.2.2 Transported material $\quad 44$

5.2.3 Discussion 46

5.3 Scanning electron microscopy 47

5.3.1 Introduction 47

5.3.2 Analytical results 47

5.3.2.1 Apatite 48

5.3.2.2 Fluorocarbonate $\quad 49$

5.3.2.3 Secondary phosphates $\quad 52$

5.3.2.4 Matrix minerals $\quad 55$

5.3.2.5 Pyrochlore $\quad 56$

5.3.3 Discussion $\quad 57$

CHAPTER 6 - GEOCHEMISTRY 59

6.1 Introduction 59

6.2 Analytical results $\quad 59$

6.3 Distribution of elements in the weathering profile $\quad 61$

6.3.1 Rare earth elements $\quad 61$

6.3.2 Major and trace elements $\quad 64$

CHAPTER 7-CONCLUSIONS 74

$\begin{array}{ll}\text { REFERENCES } & 77\end{array}$

APPENDICIES 83

Appendix A - Field description of samples 83

Appendix B - Laboratory techniques 85

Appendix C - Analytical Results 87

Table C-1: Petrography 87

Table C-2: Compositions from SEM 88

Table C-3: XRD results $\quad 89$

Table C-3: Trace and REE values from

Sun and McDonough $\quad 89$ 


\section{LIST OF TABLES}

Table 4.1 $\mathrm{P}_{2} \mathrm{O}_{5}$ analyses from Panda

Hill carbonatite

Page

32

Table 5.1 Mineral phases in the profile over Panda Hill carbonatite

Table 5.2 Fluorapatite analyses

Table 5.3 Secondary phosphates in the weathered materials

Table 6.1 Ratios of trace elements and REEs 60

Table 6.2 Major, trace and REE geochemistry 62

Table $6.3 \mathrm{Zr}$, Hf and Th concentrations 73 


\section{LIST OF FIGURES}

Page

Figure 1.1 Location of Panda Hill carbonatite 5

Figure 2.1 Regional geology of Tanzania

Figure 2.2 Location of Tanzanian carbonatites in relation to the rift system

Figure 2.3 Geology of Panda Hill carbonatite complex

Figure 4.1 Geology of the sampling area

Figure 4.2 Topography of the sampling area 31

Figure 4.3 Profile over Panda Hill carbonatite 35

Figure 6.1 Chondrite-normalized REE abundances

Figure 6.2 REE abundances in the profile

Figure 6.3a $\mathrm{P}_{2} \mathrm{O}_{5}$ and $\mathrm{CaO}$ concntrations in the profile

Figure $6.3 \mathrm{~b} \mathrm{Sr}$ and $\mathrm{Ba}$ concntrations in the profile

Figure 6.3c $\mathrm{Al}_{2} \mathrm{O}_{3}$ and $\mathrm{Fe}_{2} \mathrm{O}_{3}$ concentrations in the profile

Figure 6.4 Mantle-normalized element abundances

Figure $6.5 \mathrm{Zr}$, Hf and $\mathrm{Th}$ concentrations 


\section{LIST OF PLATES}

Page

Plate 1 Panda Hill viewed from the northeast $\mathbf{x}$

Plate 5-A1 Calcite in slightly weathered carbonatite

Plate 5-A2 Quartz and Fe-oxide in fractures

Plate 5-A3 Apatite in carbonatite

Plate 5-A4 Apatite in weathered carbonatite

Plate 5-A5 Alteration products in apatite

Plate 5-A6 Apatite in transported material

Plate 5-B1 Electron micrograph of apatite in carbonatite

Plate 5-B2 Electron micrograph of apatite and secondary phosphates

Plate 5-B3 Electron micrograph showing alteration of apatite 


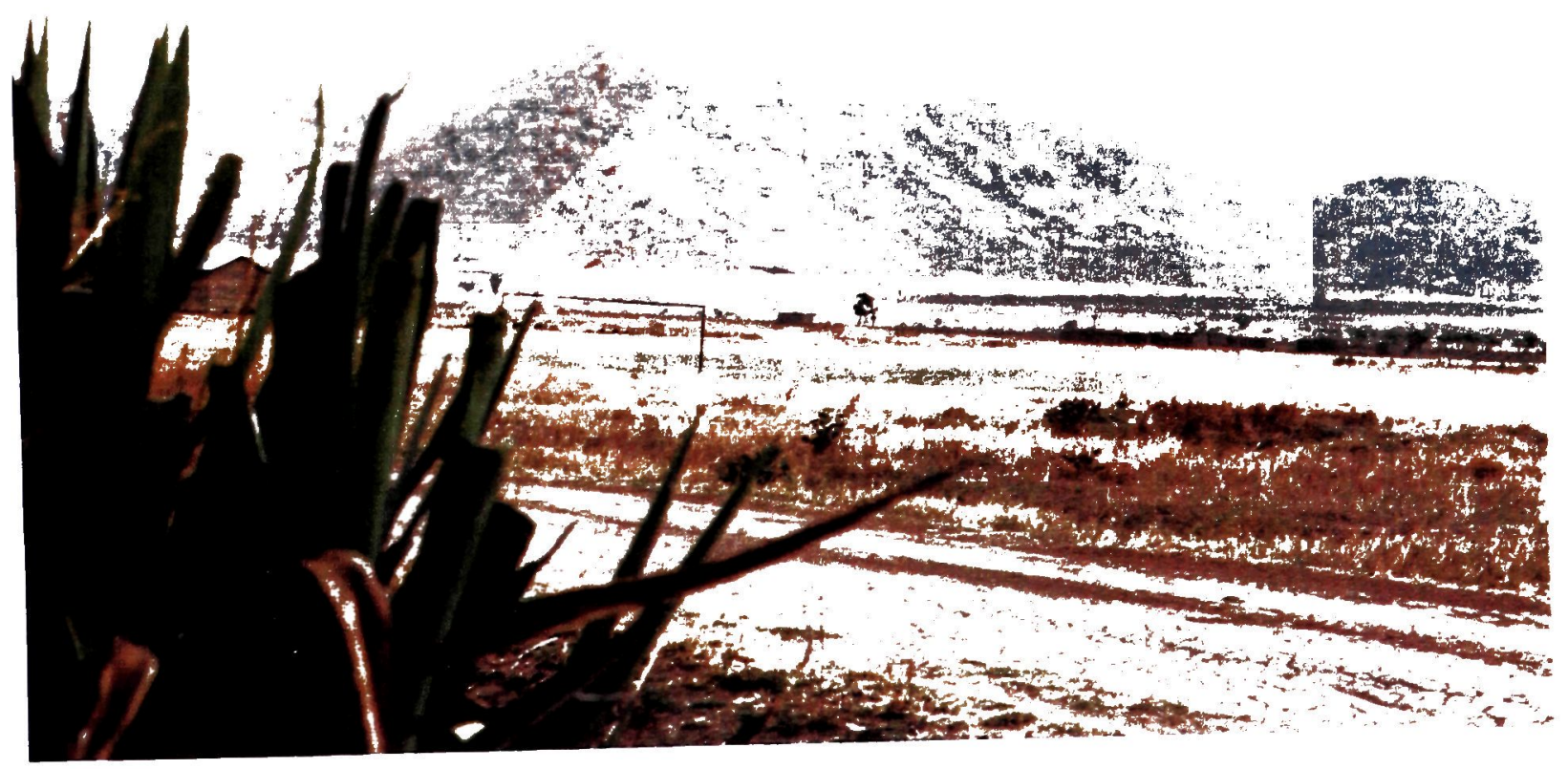

Plate 1: Panda Hill viewed from the northeast 


\section{CHAPTER 1 - INTRODUCTION}

\subsection{BACKGROUND INFORMATION}

Panda Hill carbonatite is one of the best known and best studied carbonatites in Africa. The body was first thought to be crystalline limestone in 1950 by A.M.M Spurr of the Tanganyikan Geological Survey, but was later shown to be a pyrochlore-bearing carbonatite (James, 1954). Evaluation of the carbonatite as a source for pyrochlore, (ideal formula $8\left(\mathrm{NaCaNb}_{2} \mathrm{O}_{6} \mathrm{~F}\right)$, Hogarth, 1989), was carried out by the Mbeya Exploration Company (MBEXCO) from 1955 to 1963. Panda Hill carbonatite was re-visited in 1979 by the Yugoslav Mining Association (RUDIS) in collaboration with the State Mining Corporation of Tanzania (STAMICO). The objective of this study was to evaluate the carbonatite for its phosphate potential. The first "Fertilizer Raw Materials Project" was launched. Phosphate reserves were estimated, but no follow-up work was done after the termination of the project in 1980 (RUDIS, 1980).

The utilization of fertilizers has increased greatly in tropical regions because of the increasing demand for better agricultural production, and the fact that soils are constantly being depleted of alkaline elements (i.e $\mathrm{Ca}$ and $\mathrm{Mg}$ ) and essential nutrients, including $\mathrm{N}$, P and K (McClellan and Notholt, 1986; Chesworth et al., 1988; Batiano et al., 1989). Increase in acidity leads to $\mathrm{Al}$ - and Mn-toxicity, and the high oxide mineral content leads to phosphate fixation. Fertilizer application to such soils is therefore essential if a better agricultural yield is to be obtained. Commercial fertilizers are expensive and are either not affordable or not available to the majority small-scale farmers. Many countries have, beginning in the 1970s, considered the possibility of direct application of locally-available 
raw materials. These generally require low capital investment and have low production costs (McClellan and Notholt; 1986). Attention has so far been directed to sources for phosphorus, the most problematic nutrient in acid tropical soils.

Chemical weathering of apatite-bearing carbonatites produces large, phosphate-rich residual deposits (phosphate rock), which can be used as an alternative to commercial fertilizers (Hignet, 1985; McClellan and Notholt, 1986; Batiano et al., 1989; Kpomblekou et al., 1991). A number of countries in Africa, particularly Senegal and Morocco, have done extensive field trials and laboratory experiments to assess the suitability of locallyavailable phosphate rocks. According to their findings, phosphate rock ores can be utilized after minor processing either by physical beneficiation, such as sizing and washing, or chemical processes, such as calcining and partial acidulation (McClellan and Notholt, 1986; Hammond et al, 1989; Kpomblekou et al., 1991).

In 1985 Tanzania considered re-evaluation of geological materials for fertilizer purposes during the "Agrogeology Project" that was initiated and funded by IDRC (Chesworth et al., 1988; Chesworth, 1990). The project did extensive preliminary studies on a number of geological materials to assess their suitability as sources of phosphorus, or as liming materials and soil conditioners (Chesworth et al., 1988). Work was directed to both sedimentary and igneous phosphates. Materials used for experiments and field trials were obtained from various carbonatites (i.e Panda Hill, Ngualla, Njelenje and Mbalizi) and from the sedimentary phosphate deposit at Minjingu. Because raw material from the Minjingu deposit was being used by the fertilizer industry in Tanzania, it was decided to concentrate on igneous deposits. Panda Hill was given first priority for detailed work, due 
to the large quantity of ore and accessibility.

Trials and experiments were carried out on Panda Hill material along with detailed studies of the physical, mineralogical and chemical aspects of the complex (Chesworth et al., 1988; Mchihiyo, 1990; van Straaten et al., 1992). The genesis of phosphate ore at Panda Hill through weathering was studied by Mchihiyo (1990), who established that apatite has been only slightly altered. Substitution of $\mathrm{CO}_{3}{ }^{2-}$ for $\mathrm{PO}_{4}{ }^{3-}$, which increases the reactivity of the ore, is very low. This makes the ore suitable for application, only after it has been processed and upgraded.

During weathering of phosphate-rich material, significant elements can be mobilized and redistributed as weathering proceeds, and this can affect the economic importance of the deposit. It is therefore important to establish the types, amount and distribution of significant minerals and elements, including elements which are likely to react with released $\mathrm{PO}_{4}{ }^{3-}$ ions, to form new minerals. $\mathrm{Sr}, \mathrm{Ba}$, Th and rare earth elements (REEs) are the main elements that are released together with phosphate as weathering proceeds (Mariano, 1989b). Furthermore high contents of ferrallitic elements ( $\mathrm{Fe}$ and $\mathrm{Al}$ ), are common in groundwater percolating through the residual materials in tropical climates (Anderson and Rubin, 1981; Mchihiyo, 1990; Chesworth, 1992). All of these elements, particularly the REEs, can react to form secondary phosphates in the weathering profile (Anderson and Rubin, 1981; Humphris, 1984; Hogarth, 1989; Mariano, 1989a,b; Braun et al., 1993).

The main objective of this study has been to provide more information about the weathering products above Panda Hill carbonatite, as part of the assessment of the 
deposit for phosphate potential. The study will be based on the mobilization and redistribution of phosphate and REEs within the ore, and identify preferred zones of enrichment.

\subsection{LOCATION AND ACCESSIBILITY}

Panda Hill, or the Mbeya, carbonatite is in southwestern Tanzania, at latitude $8^{\circ} 59^{\prime} \mathrm{S}$ and longitude $33^{\circ} 14^{\prime} \mathrm{E}$ (Fig. 1.1). The locality is $36 \mathrm{~km}$ WSW of Mbeya town. It can easily be reached by a motorable track from the Songwe industrial area which is situated along the Tanzania-Zambia highway. The zone of Tanzania in which Panda Hill is located has a tropical climate with about a 6 month dry season (van Chi-Borrardel, 1973). Mean annual precipitation is $600-1000 \mathrm{~mm}$. January average temperature is $24^{\circ} \mathrm{C}$ and July average temperature is $18^{\circ} \mathrm{C}$ (Davies, 1983).

\subsection{PREVIOUS WORK}

Various investigations have been conducted on Panda Hill carbonatite since its initial identification by James (1954). Geological mapping by James (1954) established that the body consists of a calcite carbonatite inner ring, surrounded by magnesio-carbonatite. Dykes of various composition were identified near the outer margins of the carbonatite. Further work by Fawley and James (1955) recognized the body as the central plug of a larger volcanic complex. Fick and van der Heyde (1959) used geological relationships and evidence from drilling to establish that the carbonatite is an exposed part of a larger, high-level volcanic intrusion.

The carbonatite is partially overlain by a thin blanket of fenitized country rocks, a 


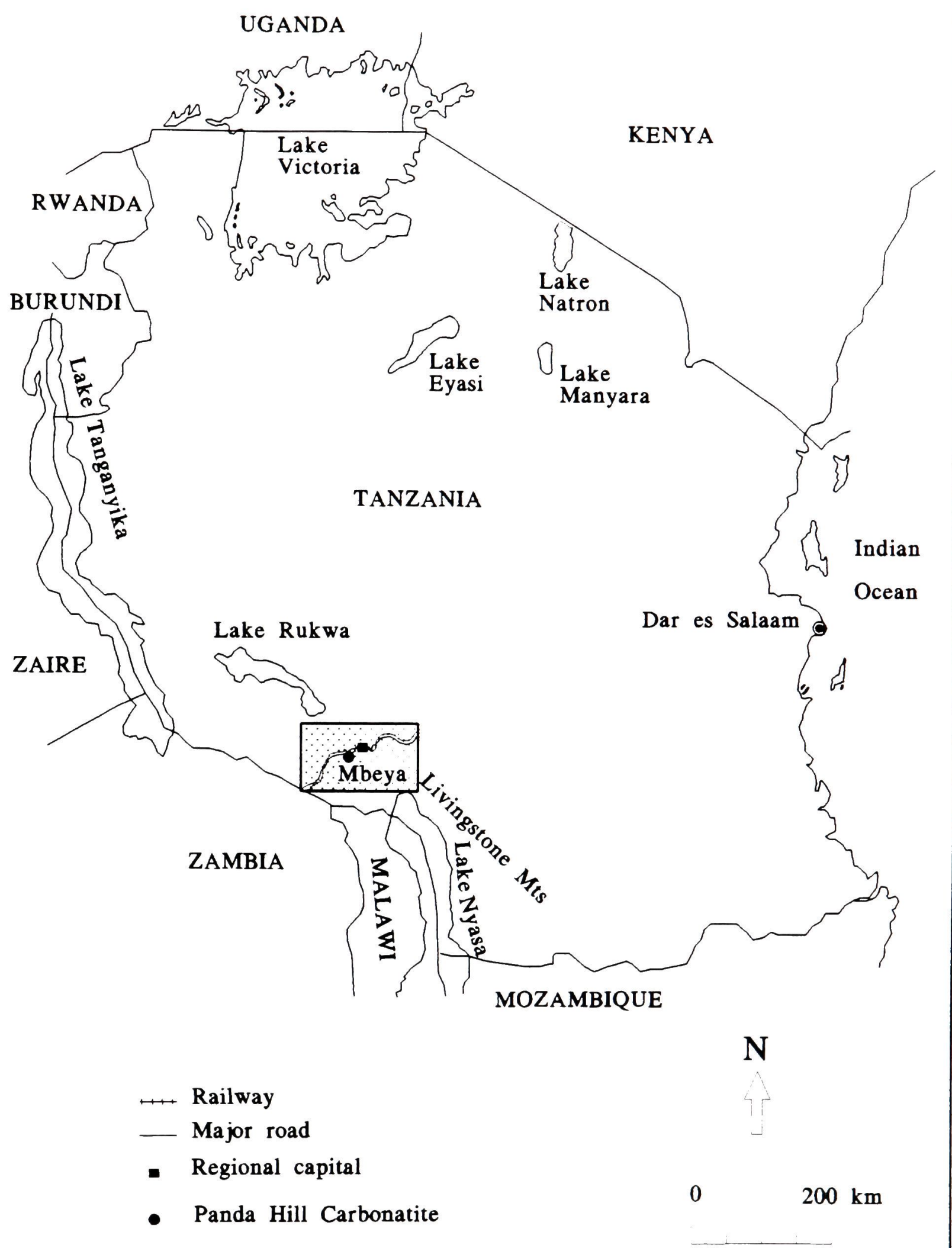

Fig. 1.1 Location of Panda Hill Carbonatite, SW. Tanzania. 
feature supported by borehole data and by recent field investigations (Chesworth, et al., 1988; van Straaten, 1989). Fenitic rocks occur at Panda Hill and these are formed by metasomatic processes brought about by expulsion of alkali-rich fluids from the intrusion, into the country rocks (McKie, 1966; Le Bas, 1989; van Straaten, 1989). The main components migrating from the magma are $\mathrm{Na}$ and $\mathrm{K}$. At Panda Hill, fenitization resulted in the formation of a shallow dipping cap, over the carbonatite, consisting of rocks marked by high K-feldspar contents (van Straaten, 1989).

The petrography and geochemistry of Panda Hill carbonatite, studied by Fick and van der Heyde (1959), and Basu and Mayila (1986), established that Panda Hill complex is dominated by calcite carbonatite with subordinate dolomite carbonatite. Dykes that cut the carbonatite consist of fine-grained brown carbonatite (ferrocarbonatite), and an apatite magnetite rock containing minor pyrochlore and some carbonates.

van Straaten (1989) reviewed the structural relationships of carbonatites in southwestern Tanzania. He established that although Panda Hill and other carbonatite bodies in the area are in or close to the East African Rift, they are not associated with rifting. Rather, they are spatially associated with repeatedly rejuvenated faults and shear zones. van Straaten argued that Panda Hill, and other Cretaceous carbonatites in the western arm of the rift, are associated with normal faults formed after the main pre-Cretaceous rifting phases and after the break-up of Gondwanaland.

The first isotopic study was by Schurmann et al. (1960), who calculated ages ranging from $273 \mathrm{Ma}$ to $68 \mathrm{Ma}$ by the U-Pb method using pyrochlore. The ages, later recalculated by Snelling (1965), fell in the 185-73 Ma range. Snelling also obtained a K-Ar date of 
$116 \pm 6 \mathrm{Ma}$ (Cretaceous) and this date has been used by recent workers (Chesworth et al., 1988; van Straaten, 1989). Bell and Blenkinsop (1989) included Sr-Nd analyses on samples from the Panda Hill carbonatite in their study of the $\mathrm{Nd}-\mathrm{Sr}$ isotope geochemistry of East African carbonatites, and obtained ${ }^{143} \mathrm{Nd} /{ }^{144} \mathrm{Nd}$ and ${ }^{87} \mathrm{Sr} /{ }^{86} \mathrm{Sr}$ ratios of 0.51242 and 0.70442 respectively. Detailed stable isotope and radioisotope geochemistry of the Panda Hill carbonatite was investigated by Morisset (1992). The $\delta^{13} \mathrm{C}$ and $\delta^{18} \mathrm{O}$ values, were close to mantle values, and she established that the carbonatite samples studied were relatively fresh. The ${ }^{86} \mathrm{Sr} /{ }^{87} \mathrm{Sr}$ and ${ }^{143} \mathrm{Nd} /{ }^{145} \mathrm{Nd}$ ratios Morisset obtained from her study indicated that either the parental carbonatite magma was generated from an isotopically homogeneous mantle source, or that the isotopic homogeneity was acquired during melting.

\subsubsection{Panda Hill as a niobium resource}

Work by the Mbeya exploration company (MBEXCO) between 1955 and 1963 evaluated the complex as a possible source of niobium. The company drilled a total of $6000 \mathrm{~m}$, dug a number of pits and trenches, and mined six galleries totalling $800 \mathrm{~m}$ in length. Mining and milling of the ore was under operation from 1957 to 1959, and 200 tons of ore was obtained per day. A pilot flotation plant was erected in 1959 for ore dressing experiments, though the ore had to be shipped to Europe for further tests. The project was terminated in 1963 (Fick \& van der Hyde 1959, Morisset 1992).

A Canadian company consulting for CIDA in 1972/73 studied the existing borehole data from MBEXCO, and recommended selective mining of pyrochlore-rich zones that contain 10 million tons of ore, at a grade of $0.64 \% \mathrm{Nb}_{2} \mathrm{O}_{5}$. No follow-up work was conducted 
after the termination of that project (RUDIS, 1980; Chesworth et al., 1988; Morisset 1992).

\subsubsection{Panda Hill as a phosphate rock resource}

The Yugoslav mining association (RUDIS), in collaboration with Tanzania's State Mining Corporation (STAMICO), formed the first "Fertilizer Raw Materials Project" in 1978/79. Using data obtained from 13 boreholes totalling 1306 m, ore reserves were calculated at 480 million tonnes. The grades of ore were $0.33 \% \mathrm{Nb}_{2} \mathrm{O}_{5}$ and $3.5 \% \mathrm{P}_{2} \mathrm{O}_{5}$ (RUDIS, 1980).

The second "Fertilizer Raw Material Project", namely the Agrogeology Project, was launched in 1985 and was jointly funded by the International Development Research Centre (IDRC) and the Government of Tanzania. The project involved geoscientists from Guelph University, Canada, and Tanzania's Sokoine University of Agriculture and the Department of Minerals. The main objective was to improve agricultural yields by using locally available geological materials which could be applied directly, or after simple and inexpensive processing techniques. Targeted beneficiaries included small-scale farmers, who could not afford commercial fertilizers (Chesworth et al., 1988; Chesworth 1990). Various materials from different localities in Mbeya and Morogoro regions were initially studied, and these included phosphate rock for P-fertilizer and limestones and other carbonate rocks for liming purposes. Although zeolites and some volcanic rocks were also considered for soil-conditioning purposes (Chesworth et al; 1988), priority was given to potential sources of P-fertilizer.

The project conducted preliminary geological mapping and exploration, laboratory 
analyses and field and greenhouse trials for the agronomic effectiveness of the materials (Chesworth et al., 1988). Panda Hill and Ngualla phosphate rock deposits proved to be good prospects in respect of tonnage, grade and initial agronomic responses. Follow-up geological work was initiated at the more accessible Panda Hill occurrence.

Mchihiyo (1990) investigated mineralogical and geochemical aspects associated with processes responsible for the accumulation of residual apatite. He established that secondary phosphates of the crandallite-gorceixite-goyazite series, hydrated oxides of $\mathrm{Al}$ and $\mathrm{Fe}$, and kaolinite occur in association with apatite. Mchihiyo showed that apatite is only slightly affected by weathering, and that this occurs at grain boundaries and fracture zones within the apatite crystals. 


\section{CHAPTER 2 - GEOLOGICAL SETTING OF THE PANDA \\ HILL CARBONATITE}

\subsection{GEOLOGY}

\subsubsection{Regional Geology}

The geology of Tanzania (Fig.2.1) consists of a central Archean craton surrounded by Proterozoic fold belts. The Tanzanian Craton, which is at least $2600 \mathrm{Ma}$ old, is dominated by linear east-west trending greenstone belts set within a granitic terrane. The granitic rocks are generally younger than the greenstone belt successions, some of the granites are older (UNDTCD, 1991; Harris, 1961).

The NW-SE trending ca 2000-1800 Ma Ubendian mobile belt lies to the southwest of the Tanzanian craton and is dominated by a variety of high-grade metamorphic rocks (commonly of the almandine-amphibolite facies). The dominant rocks are felsic gneisses and amphibolites, although granulites, late granites and marbles are also found. Parts of the belt are covered by younger sediments and volcanic rocks (UNDTCD, 1991; Harris, 1961).

The Usagaran belt (ca.650 Ma), which lies south of the craton, is dominated by high grade granulites and biotite gneisses. The belt trends easterly, but its boundary with the major ca. $500 \mathrm{Ma}$ Mozambique belt east of the craton is obscured by Karroo and Neogene sediments. The Karroo sediments, of Late Permian to Jurassic age, consist of mainly sandstones, shales 


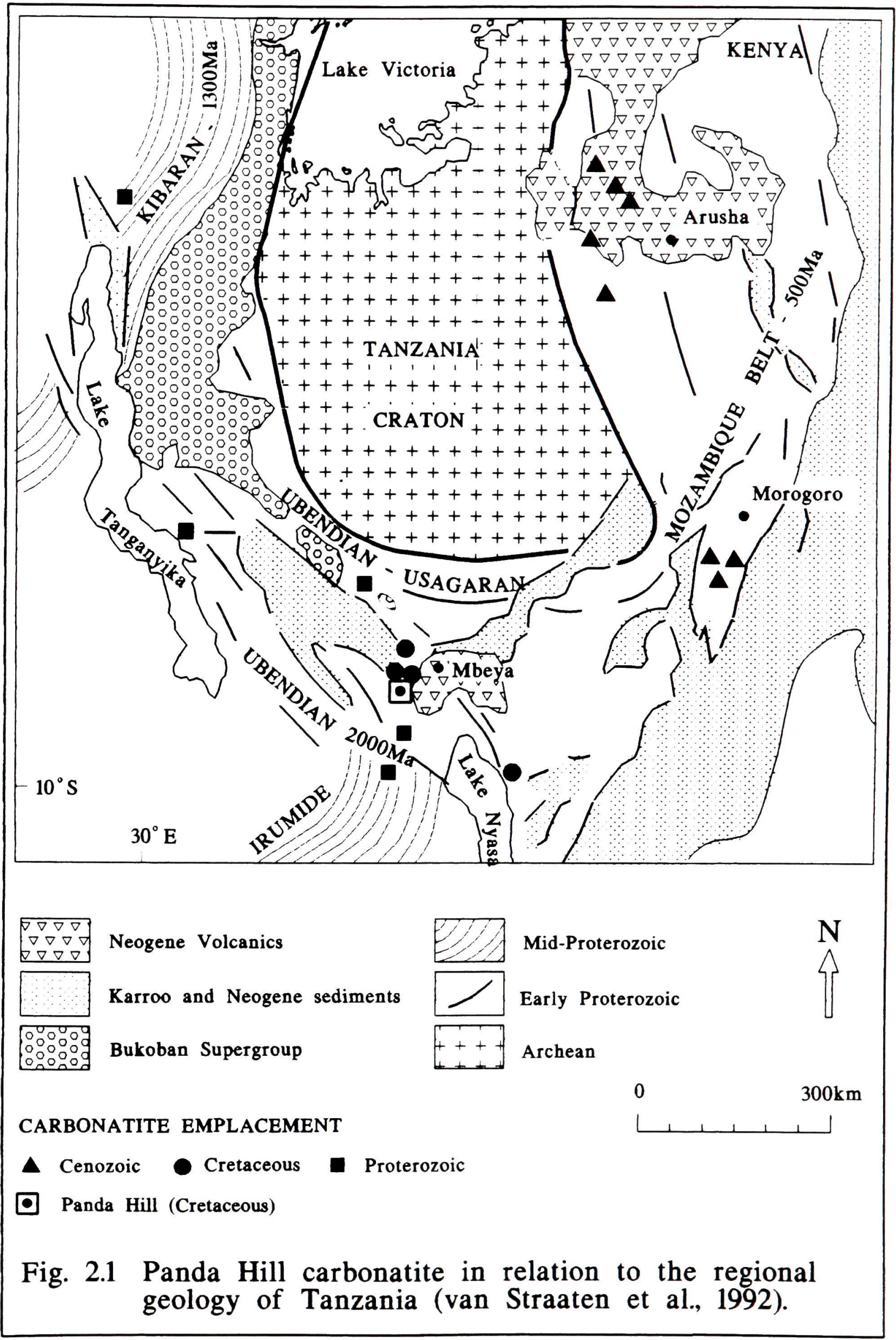


and siltstones, commonly hosting coal deposits. Neogene sediments include limestone, sandstone, shale, marls and evaporites (gypsum, anhydrite and salt) [UNDTCD, 1991].

The major rifting, which broke-up the eastern part of the African plate during the Mesozoic and Cenozoic, affected the older mobile belts surrounding the Tanzanian Craton (UNDTCD, 1991; van Straaten 1989). Two main branches of the rift system are identified in Tanzania, east and west of the central craton. Rifting created the basins that are now occupied by lakes Tanganyika, Rukwa and Nyasa in the western arm, and lakes Eyasi, Manyara and Natron in the eastern arm. Most of the known carbonatites in Tanzania occur in or close to the rift system (Fig. 2.2).

From the study of crustal structures, van Straaten (1989) observed that the distribution of carbonatite intrusions in Tanzania is controlled by repeatedly rejuvenated deep shear zones within the Proterozoic belts. Other carbonatite bodies are found close to post-Karroo faults and fault intersections, particularly the intrusions intruded during the Mesozoic. All of the Cretaceous carbonatites were intruded along shear and fault zones. From this observation, van Straaten concluded that carbonatite volcanism was preferentially along these persistently rejuvenated faults and shear structures, while rifting was a result of the reactivation of such structures. 


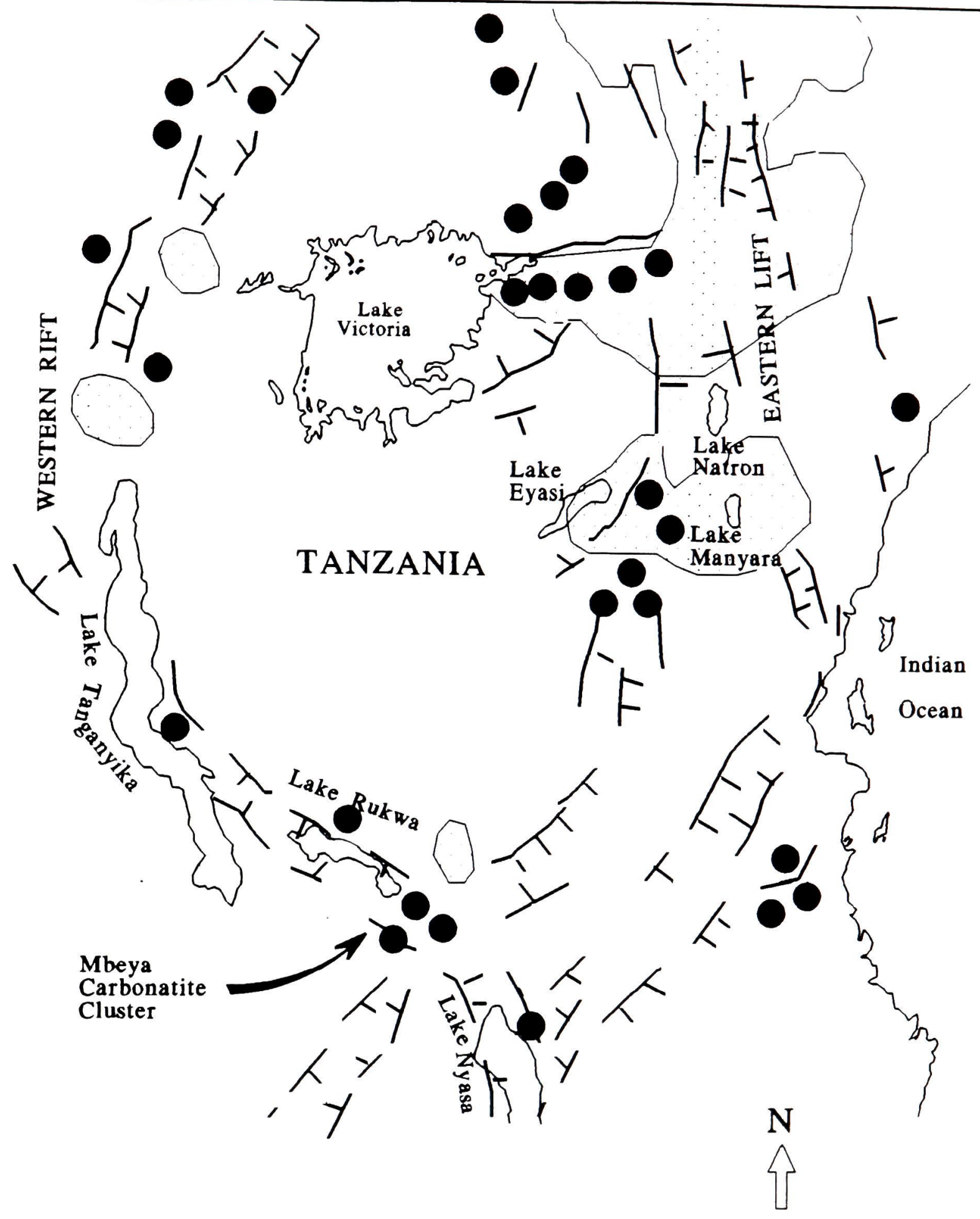

Cenozoic Volcanics
Carbonatites
Main rift faults

Fig. 2.2 Location of Tanzanian Carbonatites in relation to the East African Rift System (van Straaten et al., 1992). 


\subsubsection{Geology of Panda Hill Complex}

The Panda Hill carbonatite is mid-Cretaceous (116 $6 \mathrm{Ma}$ ) in age (Snelling, 1965). It intruded gneisses and amphibolites of the Ubendian fold belt (van Straaten, 1989; Chesworth et al., 1988) and forms a steeply dipping, near-circular plug of approximately 1.5 km diameter (James, 1954; Fawley and James, 1955; van Straaten et al, 1988). It is surrounded, and partly covered, by fenitized country rocks and residual soil material. A geological map of Panda Hill carbonatite is shown in Fig.2.3. Evidence supports three stages of carbonatite activity outwards from the centre of the plug. An early-stage calcite carbonatite forms the core, while intermediate- and late-stage carbonatites, composed of more magnesian and ferroan carbonates, form the outer parts of the plug (van Straaten, 1989; Chesworth et al., 1988). Later stage apatite-magnetite rich rocks and ferrocarbonatite dykes are also found the complex.

Fenitization of the pre-existing gneisses led to the development of potassium-rich rocks containing K-feldspar and phlogopite (van Straaten, 1989). Fenite forms a "cap" or roof over the carbonatite complex, and is in turn overlain by residual and transported soils. Volcanic ash over part of the complex suggests a later stage of volcanic activity (Chesworth et al., 1988). 


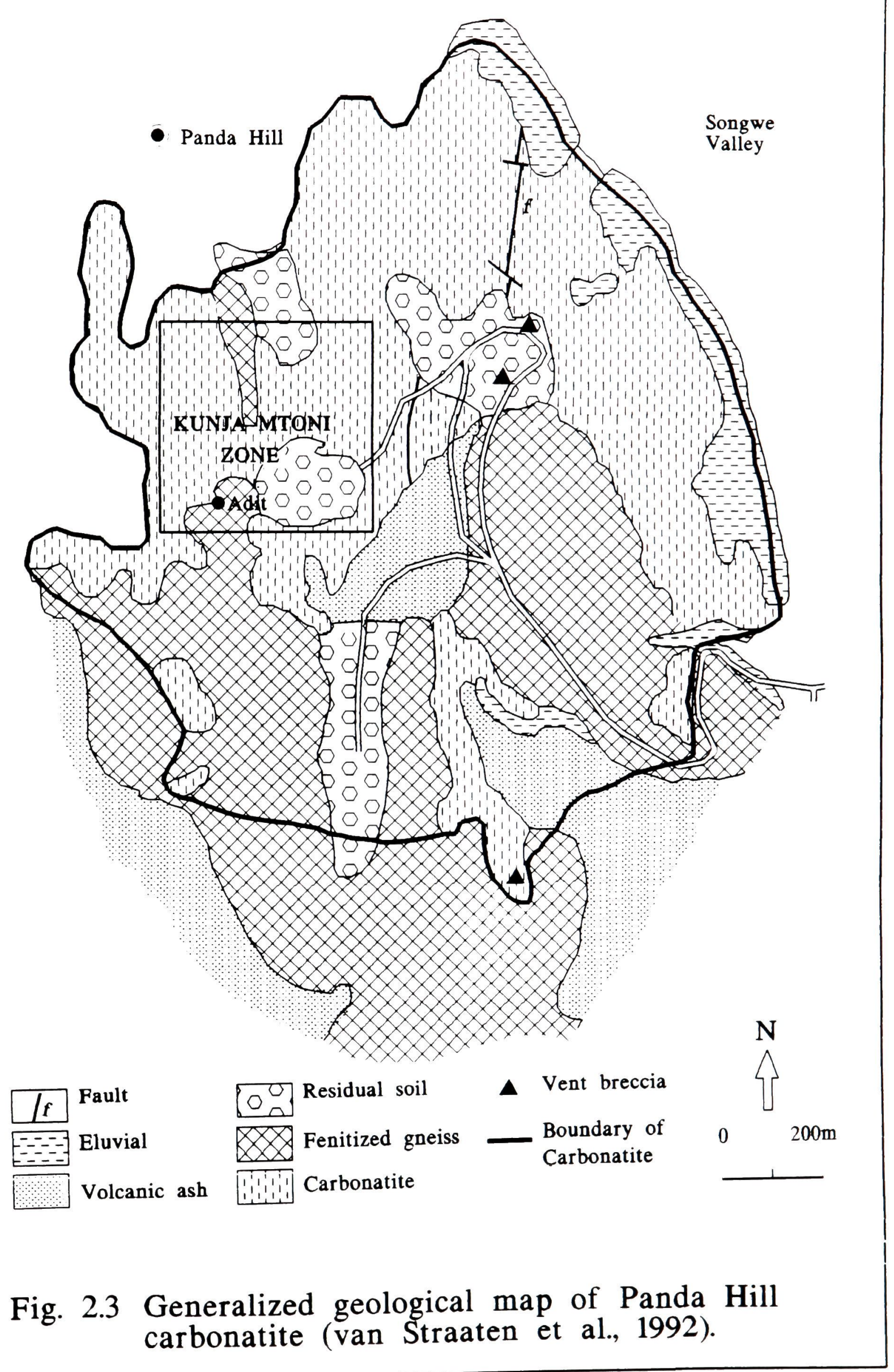




\subsubsection{Mineralogy}

Carbonatite from Panda Hill is composed mainly of calcite, which forms an average of $60-75 \%$ by volume. Samples with calcite up to $92 \%$ have been reported from Panda Hill (ESAMRDC, 1993). Apatite forms about $5-8 \%$ by volume, while pyrochlore, magnetite, phlogopite and quartz are accessory (Mchihiyo, 1990). Mchihiyo's study also established the presence of secondary minerals in the weathered rock and in residual materials. These include quartz, Fe-oxides (goethite and hematite), and clay minerals dominated by kaolinite. Other clay minerals reported are smectite and vermiculite, which are possible products from weathering of the basic volcanics.

Secondary phosphates belonging to the crandallite-goyazite- gorcexite group have been found in the weathered products from Panda Hill (Mchihiyo, 1990). The genesis, distribution within the weathering profile and chemical compositions of these minerals are discussed in Chapters five and six. The tendency of these minerals and their intermediate species to participate in the mobilization and redistribution of rare earth elements is also discussed later.

\subsection{Panda Hill Phosphate Rock}

Two important zones of phosphate mineralization were delineated by the Agrogeology Project after detailed geological work. The Kunja-Mtoni zone contains reserves estimated at 1.06 million tonnes, with an average ore grade of $10.3 \% \mathrm{P}_{2} \mathrm{O}_{5}$. Reserves for the Museum zone have not yet been estimated, since work on this zone is not complete. However, samples from two sections in this zone gave average values ranging from 12 
to $14.5 \% \mathrm{P}_{2} \mathrm{O}_{5}$ (van Straaten et al., 1992; Chesworth, et al., 1988).

The major phosphate mineral found at Panda Hill is fluorapatite. Concentrations are highest in the contact zone between carbonatite and fenitized gneiss, in late stage apatitemagnetite veins and in the overlying residual soils (Mchihiyo, 1990; van Straaten, 1989). Phosphate-rich material has residually accumulated over the carbonatite and associated rocks as a result of progressive chemical weathering, reaching to the ferrallitic stage (Mchihiyo, 1990). Ferrallitic and lateritic stages of weathering are typical of the humid tropic regions where hydrolysis is the main agent for mineral alteration (Chesworth, 1992).

The Panda Hill phosphate rock (PR) is of low activity and contains high amounts of Fe-oxides and hydroxides, and $\mathrm{Al}$ in clay minerals dominated by kaolinite (van Straaten et al., 1992; Mchihiyo, 1990). Beneficiation methods can be applied to improve the ore to commercially acceptable grades $\left(>28 \% \mathrm{P}_{2} \mathrm{O}_{5}\right)$. Washing and magnetic separation are the methods which have been used to raise the grade of Panda Hill PR ore. For example, washing a sample three times increased the $\mathrm{P}_{2} \mathrm{O}_{5}$ content from $11 \%$ to $19 \%$; and subsequent magnetic separation produced a concentrate with $36 \% \mathrm{P}_{2} \mathrm{O}_{5}$ (about $85 \%$ apatite) [Chesworth et al., 1988]. Experiments done in west Africa employed other methods including grinding, de-sliming, air classification and sizing (McClellan and Notholt, 1986). 


\section{CHAPTER 3 - PHOSPHATE ROCK}

\subsection{Background information}

Phosphate rock deposits mainly develop through the accumulation of phosphate-rich material in various geological environments. It has been established by different workers that phosphate rock (PR) can be a good alternative to the use of commercial Pfertilizers; particularly in acid soils. Depending on the quality of the material, PRs can be applied directly to soils or after minor processing, and thus they require low capital investment and production costs (Hignett, 1985; McClellan \& Notholt, 1986; Batiano et al., 1987; Hammond et al., 1989; Kpomblekou et al., 1991).

Sub-Saharan Africa is one of the tropical regions faced by severe soil infertility. Most areas of the tropics are covered by infertile Ultisols and Oxisols (Sanchez and Salinas, 1981; McClellan and Notholt, 1986; Chesworth et al., 1988). The soils are also marked by other problems including low $\mathrm{pH}, \mathrm{P}$-fixation and $\mathrm{Al}$ - and $\mathrm{Mn}$-toxicity. These problems are related to intense leaching of the soils through weathering, which has led to the development of mineral assemblages dominated by quartz-kaolinite-goethite (Sanchez and Salinas, 1981; Chesworth et al, 1988). Such soils require improvement with respect to plant nutrients, particularly for phosphorus, nitrogen and potassium. Phosphate rock is indigenous to many countries of the tropical region, and it is therefore possible to utilize the materials for P-fertilization. However, thorough studies on the available materials and economic assessment are required before attempting to utilize them, both for the benefit of the farmer and the country in question. 


\subsection{Genesis and Geological Setting of Phosphate Rock}

Phosphates occur in all geological environments i.e. sedimentary, igneous and metamorphic (Khasawneh and Doll, 1978; Hignet, 1985; McClellan \& Notholt, 1986). Igneous PR ores, such as Panda PR, are developed through residual accumulation of phosphate-rich materials during progressive chemical weathering of phosphate-bearing rocks. The primary rocks may be alkaline (carbonatites, kimberlites, syenites) or granitic. Igneous phosphates are mainly associated with carbonatites, in which fluorapatite is the major phosphate mineral.

Most of the known igneous PRs are of very low reactivity and have other undesirable physical and chemical properties (Hammond et al., 1986). They are generally coarse crystalline which makes them nearly inert for direct application (Khasawneh and Doll, 1978). Igneous PRs are considered possible sources of phosphate, mainly because their apatite minerals have compositions closer to that of fluorapatite (FA).

Sedimentary PRs, known as phosphorites, are formed through concentration of phosphate minerals in beds within marine or terrestrial sequences. Phosphate in sedimentary rocks (sandstones and limestones) occurs either as nodules or as distinct phosphatic beds forming part of the sequence (Altschular, 1973; Flicoteaux \& Lucas, 1984; McClellan \& Notholt, 1986). Such deposits also form by accumulation of bird and bat excreta, known as guano. The composition of apatites in sedimentary PRs is present as carbonate fluorapatites (CA) or francolites, formed through substitution of $\mathrm{CO}_{3}^{2-}$ for $\mathrm{PO}_{4}{ }^{3-}$ in the fluorapatite structure (Khasawneh and Doll, 1978; Flicoteaux \& Lucas, 1984; McClellan \& Notholt, 1986). Hignet (1985) established that pure apatite (FA) contains up to $42.2 \% \mathrm{P}_{2} \mathrm{O}_{5}$ but, with successive substitution of $\mathrm{CO}_{3}{ }^{2-}$ for $\mathrm{PO}_{4}{ }^{3-}$, the amounts can 
drop to $34 \%$.

Francolites have higher solubilities than fluorapatite, so their $\mathrm{P}$ is more readily available and may therefore be more effective than their igneous counterparts (Khasawneh and Doll, 1978; Anderson et al., 1985; Hammond et al., 1986). The solubility of apatite in igneous PRs can however be improved such that the ores yield higher concentrations of

bone phosphate of lime (BPL) or tricalcium phosphate $\left[\mathrm{Ca}_{3}\left(\mathrm{PO}_{4}\right)_{2}\right]$. Weight \% BPL has been used to express the phosphate contents in phosphorites. For example, beneficiation of phosphate ores derived from carbonatites give an average of 79-88 wt\% BPL compared to $77 \mathrm{wt} \%$ BPL produced by the beneficiation of marine phosphorites (Mariano, 1989a). Though their phosphate contents are lower, marine phosphorites are the world's most utilized ores for phosphate production (Mariano, 1989a).

\subsection{Classification of Phosphate Rock}

The classification of PR is based mainly on the composition of the phosphate minerals. McClellan and Gremillion (1978) classified phosphate ores according to increasing economic importance as follows:

I. Fe-Al Phosphates, the most common members being wavellite $\left[\mathrm{Al}_{3}\left(\mathrm{PO}_{4}\right)_{2}(\mathrm{OH})_{3} .5 \mathrm{H}_{2} \mathrm{O}\right]$, variscite $\left(\mathrm{AlPO}_{4} \cdot 2 \mathrm{H}_{2} \mathrm{O}\right)$ and strengite $\left(\mathrm{FePO}_{4} \cdot 2 \mathrm{H}_{2} \mathrm{O}\right)$

II. Ca-Fe-Al Phosphates, including crandallite $\left[\mathrm{CaAl}_{3}\left(\mathrm{PO}_{4}\right)_{2}(\mathrm{OH})_{5} \cdot \mathrm{H}_{2} \mathrm{O}\right]$ and millisite $\left[(\mathrm{Na}, \mathrm{K}) \mathrm{CaAl}_{6}\left(\mathrm{PO}_{4}\right)_{4}(\mathrm{OH})_{9} \cdot 3 \mathrm{H}_{2} \mathrm{O}\right]$

III. Ca-phosphates, consisting of minerals of the apatite group. Members of this group are the series from fluorapatite $\left[\mathrm{Ca}_{5}\left(\mathrm{PO}_{4}\right)_{3} \mathrm{~F}\right]$ to hydroxyapatite $\left[\mathrm{Ca}_{5}\left(\mathrm{PO}_{4}\right)_{3} \mathrm{OH}\right]$. Intermediate species are carbonate apatites, formed by substitution of $\mathrm{CO}_{3}{ }^{2 \cdot}$ for 
$\mathrm{PO}_{4}{ }^{3-}$ in the apatite structure, and are chemically expressed as $\mathrm{Ca}_{5}\left(\mathrm{PO}_{4}, \mathrm{CO}_{3}\right)_{3}(\mathrm{OH}, \mathrm{F})$ [Nriagu,1984].

Chemically, PRs are classified according to grade of ore, determined by the amount of total phosphate $(\mathrm{P})$. High grade PRs contain $>16 \%$; medium grade $14-15.9 \%$, and low grade $<14 \%$ total P (British Sulphur Corp. Ltd, 1971). The reactivity of PR, which is a function of total $\mathrm{P}$ and the composition of the phosphate mineral in the rock, is determined by the solubility of PR in citric acid, formic acid or neutral ammonium citrate (Hignet, 1985; Hammond et al., 1986). Diamond (1979), as quoted by Batiano et al., (1987) proposed that the reactivity of a PR is high if its citrate solubility is $\geq 5.4 \%$. PRs with citrate solubilities from $3.2-4.5 \%$ are medium, while those with solubility $<2.7$ are of low reactivity.

\subsection{WEATHERING OF CARBONATITES}

\subsubsection{Introduction}

Carbonatites are generally defined as igneous rocks containing $>50 \%$ carbonate minerals (Haggerty,1989; Wooley \& Kempe, 1989). Intrusive carbonatites are dominated by carbonates of calcium, magnesium and iron, and depleted of alkalis. They are named according to the dominant carbonate species, i.e. calcite carbonatite, dolomite carbonatite, ankerite carbonatite, etc. Natrocarbonatite is the name given to extrusive carbonatites composed mainly of sodium and potassium carbonates, such as the flows associated with the active Oldoinyo Lengai carbonatite volcano in northern Tanzania (Dawson, 1989; Gittins, 1989; Wooley \& Kempe, 1989). Some carbonatites, however, may be formed by hydrothermal activity or as replacement bodies (Barker, 1989). The 
number of known minerals associated with carbonatites and the weathered crusts overlying them reaches up to 280 (Hogarth, 1989). However, most of the minerals are either rare or are not typical of many carbonatites (Hogarth, 1989). Apart from the major carbonate components, other common minerals in carbonatites are apatite, pyrochlore, magnetite, phlogopite, bastnaesite and amphibole (Hogarth, 1989; Haggerty, 1989; Wooley and Kempe,1989). Carbonatites are also potential bearers of $\mathrm{Ba}, \mathrm{Sr}, \mathrm{Nb}$, P, Ti, Zr, and REEs (Wambeke, 1960; Hamilton et al., 1989; Hogarth, 1989; Mariano, 1989a,b; van Straaten, 1989 ; Wooley and Kempe, 1989). Other important elements include fluorine, thorium and tantalum.

Carbonatites are generally coarse grained (Wooley \& Kempe,1989) and are known to develop internal drainage (Mariano, 1989a). Fluids from thermal springs associated with carbonatites permeate the carbonatites and trigger dissolution of the most soluble carbonate minerals (Mariano, 1989a). This stage is characterized by the removal of Ca and $\mathrm{Mg}$ from the system and the release and remobilization of REEs (Mariano, 1989b). The REEs are then transported by groundwater, channelled in fractures and reprecipitated as REE-fluorocarbonates (Mariano, 1989b). Dissolution of primary carbonates in carbonatite is accompanied by the appearance of clays and hydrous oxides of aluminum and iron, and the accumulation of more-resistant apatite, pyrochlore, magnetite, etc. (Reedman, 1984; Mariano, 1989a; Braun et al., 1990; Mchihiyo, 1990).

Progressive chemical weathering leads to continuous dissolution of carbonates, increased clay and $\mathrm{Al}-\mathrm{Fe}$ oxides, and the breakdown of apatite and pyrochlore. Calcium, phosphate and other significant elements, e.g. Sr, Ba, and REEs, contained in the more resistant primary minerals may be released at this stage. This stage of chemical 
weathering is accompanied by formation of new minerals by recrystallization, and/or through substitution of some elements for $\mathrm{Ca}^{2+}$ and $\mathrm{PO}_{4}{ }^{3-}$ in the apatite structure, and $\mathrm{Na}^{+}$and $\mathrm{Ca}^{2+}$ in the pyrochlore structure (Humphris, 1984; Hogarth, 1989; Mariano, 1989a; Braun et al., 1990). Another common phenomenon is the preferential incorporation of some released ions, including phosphate and REEs, into exchange sites on clays and Al-Fe oxides (Khasawneh and Doll, 1978; Humphris, 1984; Hammond et al., 1986; Braun et al., 1993).

Apatite and pyrochlore are very resistant minerals and may survive a complete weathering cycle with only slight modifications of their shape. However, progressive hydrolysis may lead to formation of secondary phosphates, e.g., crandallite group minerals as overgrowths on the primary apatite crystals (Mariano, 1989a). Furthermore, complexes are known in which primary apatite has been destroyed completely by intensified lateritic weathering, such as at Araxá and Catalao I in Brazil (Mariano, 1989a,b).

\subsubsection{Supergene Formation of Phosphate minerals}

Known phosphate minerals exceed 250 (Clark, 1984; Flicoteaux and Lucas, 1984; Nriagu, 1984; Vieillard and Tardy, 1984). The most common are minerals of the apatite family with the general formula $\mathrm{A}_{5}\left(\mathrm{XO}_{4}\right)_{3}(\mathrm{~F}, \mathrm{OH}, \mathrm{Cl})$, where A may be $\mathrm{Ca}, \mathrm{Pb}, \mathrm{Sr}, \mathrm{Ba}$, and $\mathrm{X}$ may be $\mathrm{P}, \mathrm{S}$, or $\mathrm{V}$. The main species of the apatite group are fluorapatite $\left[\mathrm{Ca}_{5}\left(\mathrm{PO}_{4}\right)_{3} \mathrm{~F}\right]$, hydroxyapatite $\left[\mathrm{Ca}_{5}\left(\mathrm{PO}_{4}\right)_{3} \mathrm{OH}\right]$, and their carbonate-derivatives which form by substitution of $\mathrm{CO}_{3}^{3-}$ for $\mathrm{PO}_{4}{ }^{3-}$ in the apatite structure (Flicoteaux and Lucas, 1984 Nriagu, 1984; Hogarth, 1989). Chlorapatite is less common due to the low contents of chlorine in 
apatite as compared to fluorine. Normally F:Cl is $180: 1$ in sedimentary apatite and 17.5:1 in igneous apatite (Liu, 1981 as quoted by Hogarth, 1988).

Phosphate minerals resulting from the weathering of primary apatite are also included in the apatite series. Examples are crandallite $\left[(\mathrm{Ca}, \mathrm{REE}) \mathrm{Al}_{3}\left(\mathrm{PO}_{4}\right)_{2}\left(\mathrm{OH}_{5} \cdot \mathrm{H}_{2} \mathrm{O}\right)\right]$, florencite $\left[(\mathrm{REE}) \mathrm{Al}_{3}\left(\mathrm{PO}_{4}\right)_{2}(\mathrm{OH})_{6}\right.$, and the strontium $(\mathrm{Sr})$ - and barium (Ba)-bearing members, e.g gorceixite $\left[\mathrm{BaAl}_{3}\left(\mathrm{PO}_{4}\right)\left(\mathrm{PO}_{3} \mathrm{OH}\right)(\mathrm{OH})_{6}\right]$ and goyazite $\left[\mathrm{SrAl}_{3}\left(\mathrm{PO}_{4}\right)_{2}(\mathrm{OH})_{5} \mathrm{H}_{2} \mathrm{O}\right]$. These minerals are formed by substitution of $\mathrm{Sr}, \mathrm{Ba}$ or REEs for $\mathrm{Ca}^{2+}$ in the apatite structure (Clark, 1984; Nash, 1984; Mariano, 1989a; Braun et al,1990; Spotl, 1990). Secondary phosphates can recrystallize when phosphate and other elements released from primary minerals interact in other parts of the profile. Common examples are the formation of rhabdophane (REE) $\mathrm{PO}_{4} \cdot \mathrm{H}_{2} \mathrm{O}$ and monazite (REE) $\mathrm{PO}_{4}$. Aluminum and Fe-phosphates, e.g. wavellite $\left[\mathrm{Al}_{3}\left(\mathrm{PO}_{4}\right)_{2}(\mathrm{OH})_{3} .5 \mathrm{H}_{2} \mathrm{O}\right]$ and strengite $\left(\mathrm{FePO}_{4} \cdot 2 \mathrm{H}_{2} \mathrm{O}\right)$, also form where ferrallitic and lateritic weathering occur, and the aqueous phase is charged with $\mathrm{Al}^{3+}$ and $\mathrm{Fe}^{3+}$ as well as $\mathrm{PO}_{4}{ }^{3-}$ ions (Anderson \& Rubin, 1981).

As discussed earlier, apatite has a high resistance to weathering and may be found in the form of only slightly-altered crystals in weathered crusts above carbonatite bodies. However, based on the many weathering products that have been reported, this author is of the opinion that secondary phosphate minerals may be an important component of the total phosphate in a particular phosphate rock ore, especially in ores from deeplyweathered crusts. It is therefore important to study the type and distribution of phosphate mineralization in strongly-weathered carbonatites as part of any assessment procedure. The presence of such secondary phosphate minerals may influence the requirements for ore upgrading processes. 


\subsubsection{Redistribution of REEs during weathering}

Weathering of carbonatites initiates mobilization and redistribution of REEs within the profile, and since REEs preferentially form compounds with phosphate in an aqueous system (Mariano, 1989a), it is important to include the study of REEs during assessment of phosphate ores. Rare earth elements include the lanthanides, lanthanum (La) to lutetium (Lu), atomic numbers 57 to 71; and yttrium (Y) [Vlasov, 1966; Henderson, 1984]. The elements are classified into light and heavy elements. Light rare earths (LREEs) include the elements from $\mathrm{La}$ to $\mathrm{Sm}$, while those from $\mathrm{Gd}$ to $\mathrm{Lu}$ are classified as heavy rare earths (HREEs). Rare earth elements are all similar in chemical and physical properties (Vlasov, 1966 Henderson, 1984).

Yttrium, atomic number 39, is included in the group due to its similarities to HREEs with regard to its crystallochemical and chemical properties. Yttrium has an ionic radius of $1.06 \AA$, close to that of dysprosium (Dy) [Vlasov, 1966]. REEs have other characteristic properties which are not found in ordinary elements. One special characteristic is that the innermost $4 \mathrm{f}$ electron sublevel is filled in successive elements instead of the outer level, as is the case in ordinary elements in their period (Vlasov, 1966).

Investigations on the sources of REEs in various types of rocks have established that the elements occur either as independent REE minerals or as parts of the structures of other minerals (Clark, 1984; Cullers and Graf, 1984; Humpris, 1984; Hogarth, 1989; Mariano, 1989a; Wyllie, 1989; Braun, et al., 1993). The REE minerals may have formed through magmatic, hydrothermal or supergene (weathering-type) processes (Vlasov, 1966; Mariano, 1989a,b). Individual REE minerals are not common in early stage carbonatites, but appear in intermediate and later stages; and they form together with other 
carbonatite magma crystallites i.e. calcite, dolomite, apatite, pyrochlore, etc. The most common primary REE minerals are the fluorcarbonates, i.e bastnaesite $\left[(\mathrm{REE})\left(\mathrm{CO}_{3}\right) \mathrm{F}\right]$, parisite $\left[\mathrm{Ca}(\mathrm{REE})_{2}\left(\mathrm{CO}_{3}\right)_{3} \mathrm{~F}_{2}\right]$ and synchysite $\left[\mathrm{Ca}(\mathrm{REE})\left(\mathrm{CO}_{3}\right)_{2} \mathrm{~F}\right]$, though monazite (REE) $\mathrm{PO}_{4}$ may form by recrystallization if $\mathrm{REE}$ and $\mathrm{PO}_{4}{ }^{3-}$ are released from primary minerals by early stage weathering (Clark, 1984; Mariano, 1989a). Textural features (grain size and shape) and mineral paragenesis are the main criteria used to determine that the minerals are primary.

REEs in carbonatites are contained in primary carbonate minerals (bastnaesite and calcite), in phosphates (apatite and monazite) and in oxides (pyrochlore and peroviskite) [Clark, 1984; Hamilton, et al., 1989; Hogarth, 1989; Mariano, 1989a; Wooley and Kempe, 1989; Wyllie, 1989). Mariano (1989a), based on work by Loubet et al., (1972), Eby (1975) and, Moller et al., (1980), established that the total REE contents in carbonatites varies from 500 to over $10,000 \mathrm{ppm}$. According to these workers, REE contents rarely exceed $200 \mathrm{ppm}$ in sedimentary carbonates.

Hydrothermal REE minerals are formed when hydrothermal solutions charged with REEs, Sr, F, Ba and Si invade country rocks (Mariano, 1989a,b). These minerals are therefore found in veins, veinlets and void fillings, as in the case of bastnaesite at the Wigu Hill carbonatite in Tanzania (Mariano, 1989a,b). Hydrothermal REE minerals are commonly associated with other secondary minerals such as hematite, goethite, quartz, strontianite and fluorite (Mariano, 1989a).

Weathering is the main cause of the release of REEs from primary minerals. This leads to subsequent supergene REE enrichment, particularly in the humid tropics, and in areas where basin-type topography allows accumulation of residual minerals (Mariano, 1989b). 
An example is the Araxà phosphate deposit in Brazil (Mariano, 1989b). Under lateritic weathering, $\mathrm{Ca}$ and $\mathrm{Mg}$ are removed from the system by dissolution of carbonates, and the less mobile REEs, $\mathrm{Sr}, \mathrm{Ba}$, and $\mathrm{Th}$ are incorporated into mineral phases, particularly apatite and undissolved carbonates (Mariano, 1989a). The common minerals formed are monazite, gorceixite and goyazite. Florencite forms in the presence of $\mathrm{Al}$, and cerianite $\left(\mathrm{CeO}_{2}\right)$ forms under high oxidizing conditions where $\mathrm{Ce}^{3+}$ is oxidized to $\mathrm{Ce}^{4+}$. The dissolution of carbonates and breakdown of apatite allows the fractionation, mobilization and redistribution of REEs and $\mathrm{PO}_{4}{ }^{3-}$ in the weathering system (Nesbitt, 1979; Duddy, 1980; Humphris, 1984; Mariano, 1989a; Braun et al., 1993).

The fractionation and mobilization of the REEs depends on factors such as their abundance, distribution, and the sites of their concentration in the primary minerals (Nesbitt, 1979; Humphris, 1984). Other factors include the stability of the REE-bearing primary minerals during weathering, and the concentration of REEs in the fluid and the fluid's ability to translocate them (Humphris, 1984). The released elements may be rendered immobile elsewhere in the profile by mechanisms such as retention in resistant primary minerals, incorporation into recrystallized minerals, and adsorption by clays and hydrous Fe-Al oxides (Humphris, 1984; Braun et al, 1993).

Humphris (1984) also attributed the mobilization of REEs to $\mathrm{pH}$ conditions. According to Humphris, water with a $\mathrm{pH}$ lower than 5.7 will favour the solution and transportation of REEs. She established that an increase in $\mathrm{pH}$ above 5.7 will favour precipitation of REEs as hydroxides or carbonates, the exchange of REEs for $\mathrm{H}^{+}$on sites in other compounds, and their adsorption onto other minerals.

The type of supergene REE minerals formed in a weathering profile therefore depends 
on the ions in solution which can form compounds with the REEs. A solution charged with $\mathrm{Al}$, for example, favours the precipitation of florencite $\left[(\mathrm{REE}) \mathrm{Al}_{3}\left(\mathrm{PO}_{4}\right)(\mathrm{OH})_{6}\right]$, while rhabdophane [(REE) $\mathrm{PO}_{4} \cdot \mathrm{H}_{2} \mathrm{O}$ ] forms in the absence of aluminum (Braun et al., 1990). Studies have also established that HREEs (Gd-Lu) are more mobile than LREEs (LaEu). HREEs (Gd-Lu) are generally concentrated at the base of saprolite, whereas LREEs (La-Eu) dominate upper zones of the profile (Nesbitt, 1979; Sholkvitz, 1992; Braun et al., 1993). 


\section{CHAPTER 4 - FIELD WORK}

\subsection{Introduction}

Geological mapping of the part of the Panda Hill carbonatite rich in $\mathrm{P}_{2} \mathrm{O}_{5}$ was conducted by the Agrogeology Project as discussed in previous chapters. In 1993 field work was carried out in the same area in order to collect samples for the study of the distribution of phosphate and REEs in weathering profiles above the carbonatite and associated rocks at Panda Hill.

Figures 4.1 and 4.2 present the geology and topography of the sampled area, which falls within the northern half of the Kunja-Mtoni grid delineated by the Agrogeology Project. Selected existing pits in this area were cleaned for pit documentation and sampling. Pit selection was based on the phosphate $\left(\mathrm{P}_{2} \mathrm{O}_{5}\right)$ analysis that had been conducted by the Agrogeology Project. During the project the $\mathrm{P}_{2} \mathrm{O}_{5}$ analyses were initially determined in an on-site laboratory and then verified at the University of Guelph (van Straaten et al., 1992). In addition, samples were obtained from two Agrogeology project drill holes. The latter were necessary because a complete weathering profile was desired and none of the pits extended down to unweathered carbonatite bedrock. The locations of the sampled pits and drill holes are included in Figures 4.1 and 4.2. Table 4.1 presents $\mathrm{P}_{2} \mathrm{O}_{5}$ analyses from some of the re-sampled pits and drill holes. 

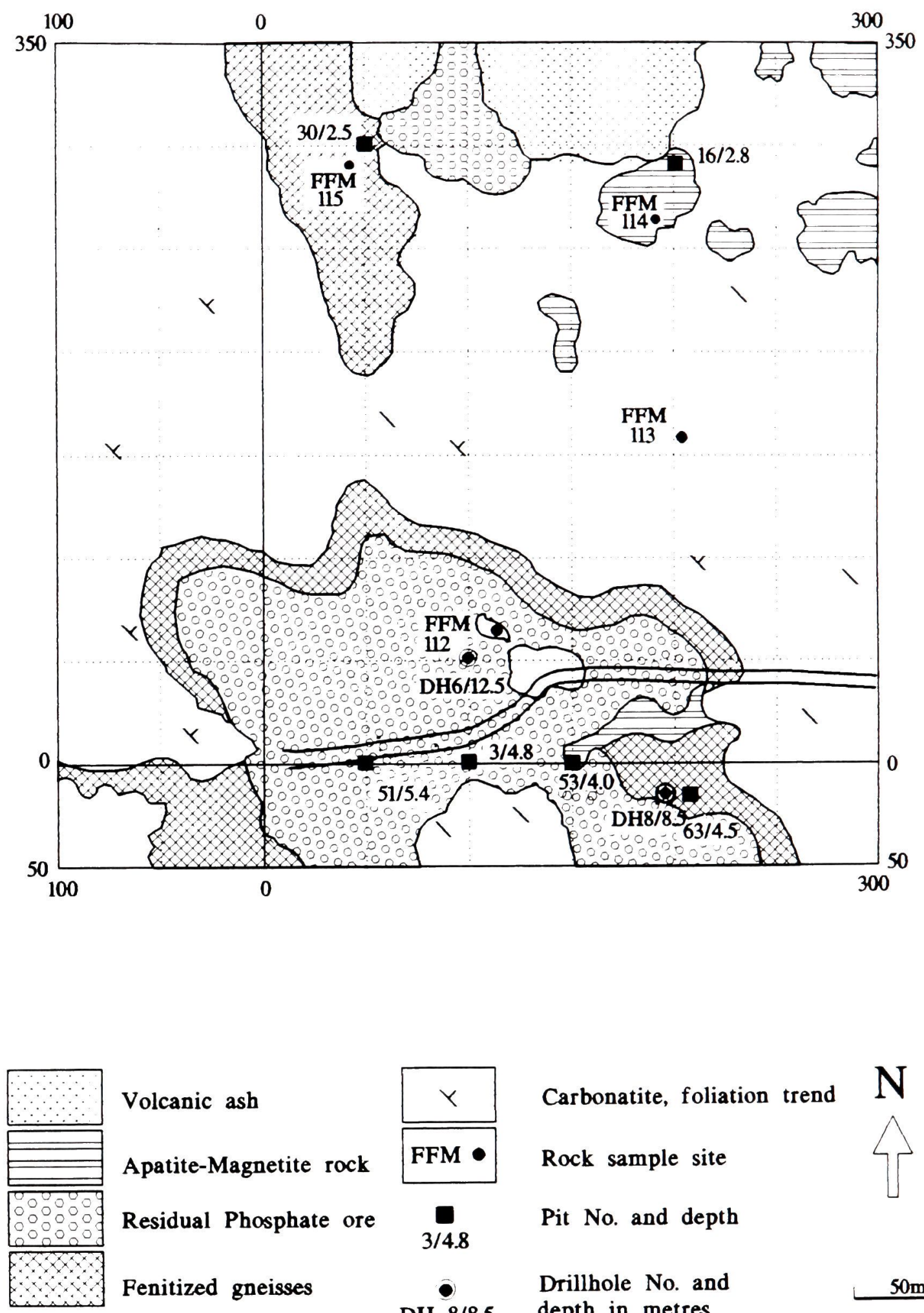

Volcanic ash

Apatite-Magnetite rock

Residual Phosphate ore

Fenitized gneisses

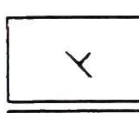

FFM

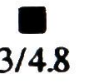

$3 / 4.8$

Drillhole No. and DH $8 / 8.5$ depth in metres
Carbonatite, foliation trend

Rock sample site

Pit No. and depth

$50 \mathrm{~m}$

Fig. 4.1 Geology of study area within Kunja-Mtoni grid showing pit and drill hole locations and depths. 


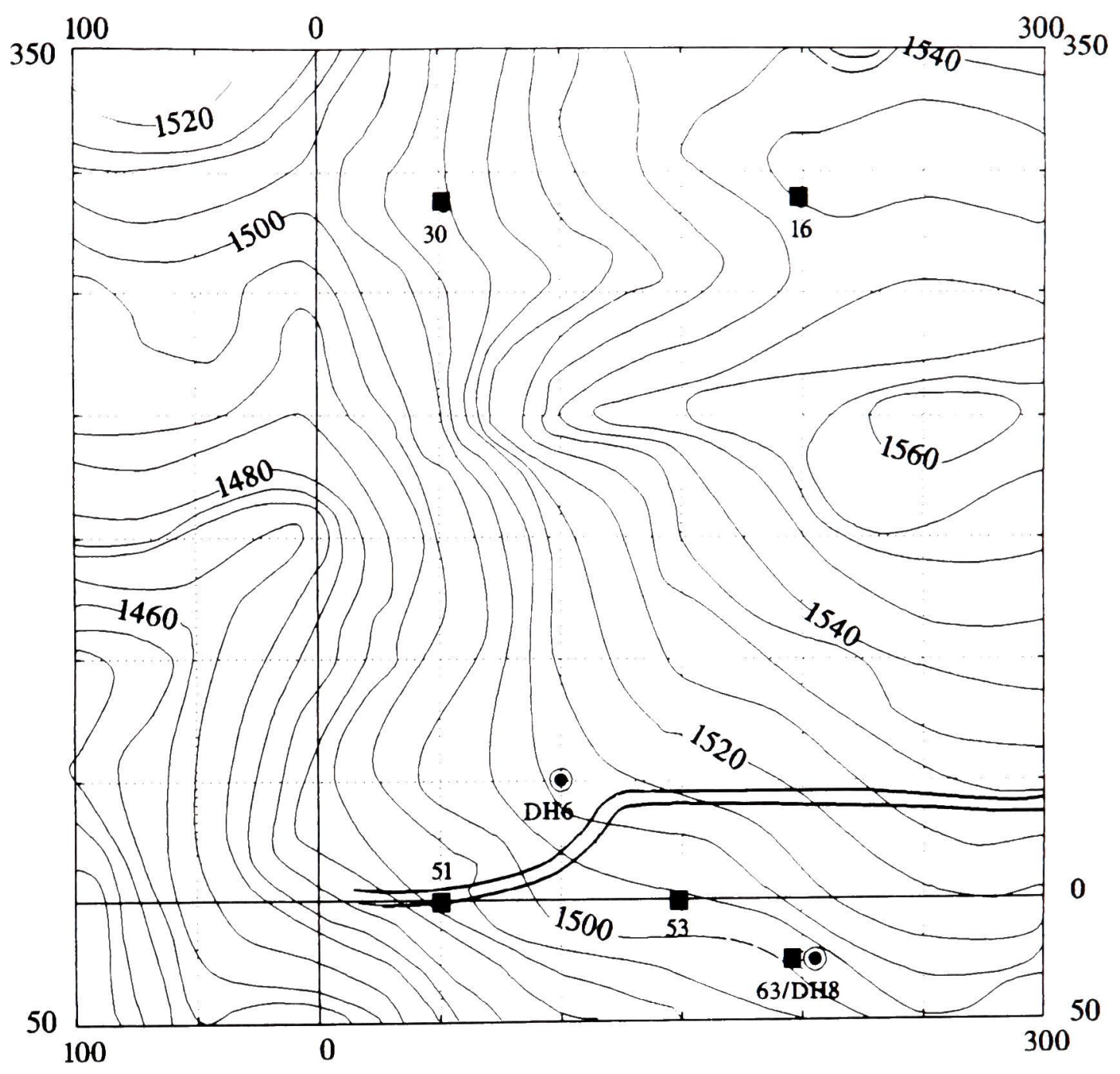

$\begin{aligned} &-1500- \text { Elevation } \\ & \text { in Metres } \\ & \text { at } 5 \mathrm{~m} \\ & \text { intervals }\end{aligned}$
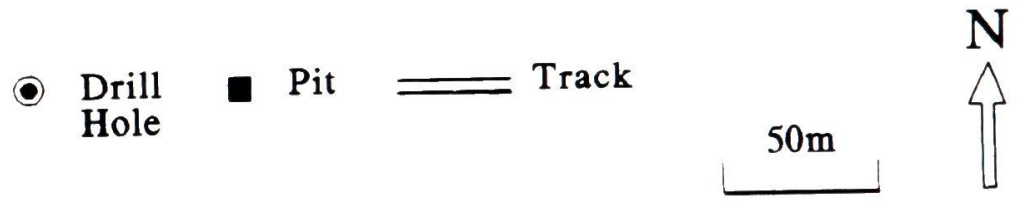

Fig. 4.2 Topography of study area showing elevations at pit and drill hole locations (modified after van Straaten et al., 1992). 
Table 4:1. Selected $\mathrm{P}_{2} \mathrm{O}_{5}$ analyses of samples from Panda Hill carbonatite complex (after van Straaten et al., 1992)

\begin{tabular}{||l|l|l|l|l|l||}
\hline \hline Pit/DH \# & Depth $(\mathrm{m})$ & P2O5 (\%) & Pit\# & Depth (m) & P2)5 (\%) \\
\hline $\mathbf{1 6}$ & -0.35 & 11.01 & $\mathbf{5 1}$ & -0.20 & 16.38 \\
\hline & -0.85 & 17.60 & & -0.70 & 13.30 \\
\hline & -1.35 & 26.66 & & -1.20 & 17.44 \\
\hline & -1.85 & 21.00 & & -1.70 & 20.00 \\
\hline & -2.35 & 18.50 & & -2.20 & 18.30 \\
\hline DH 6 & -3.25 & 7.00 & & -2.70 & 20.25 \\
\hline & -4.25 & 2.00 & & -3.20 & 13.30 \\
\hline & -7.15 & 9.50 & & -3.70 & 9.15 \\
\hline & -8.15 & 1.50 & & -4.20 & 7.44 \\
\hline & -12.15 & 8.00 & & -4.70 & 17.68 \\
\hline & & & & -5.20 & 20.02 \\
\hline
\end{tabular}

Samples of weathered materials were collected at $0.25 \mathrm{~m}$ intervals from the top two metres, followed by one sample from each distinctive zone down the rest of the pit. Zones were differentiated on the basis of macroscopic changes, mainly colour and texture. A total of 118 rock, weathered material and soil samples were collected. The weathered material and soil samples were about 200 to $300 \mathrm{gm}$ each.

Representative samples for the different rock types were obtained from outcrop. Carbonatite rock samples were obtained from the cores recovered by drilling. Analyses were conducted on core samples from drill hole DH6. 


\subsection{Field results}

The field descriptions of drill hole \#6 and pits 16,30 and 51 from Panda Hill complex are presented in Appendix A, Table A-1. A generalized discussion of the profiles is presented in this section.

\subsubsection{Profile over carbonatite}

A complete profile consists of the bedrock and three other distinctive zones above it, namely, the residual soil zone immediately above carbonatite, the zone of colluvium or transported materials, and the top soil (Mchihiyo, 1990). This study has differentiated two subzones each for the bedrock and residual material zones, i.e. unweathered and weathered carbonatite, and lower and upper saprolite. Observed variations in zonal thickness are common, and can be explained when topographical differences are considered. Residual materials commonly form thicker zones on the lower slopes compared to higher-slope locations. The profile analyzed is from drill hole \#6, located in the lower slopes of the Panda Hill complex. The profile formed above carbonatite and consists of horizon A (up to $0.3 \mathrm{~m}$ thick), horizon B (4.7 m thick), and the C horizon (up to $3 \mathrm{~m}$ thick).

The profile is diagramatically presented in Figure 4.3. The thicknesses of each of the zones refer specifically to this particular profile which includes only the portion of the carbonatite zone recovered from the drill hole. Description of the zones are as follows: ia) Slightly-weathered carbonatite, $>8 \mathrm{~m}$ depth. The rock is course grained, and white to gray in color. 
ib) Moderately-weathered carbonatite $7.05-8 \mathrm{~m}$ depth. The subzone is highly fractured and contains reddish brown alteration products, infilling fracture zones.

iia) Saprolite, 4.0-7.05 $\mathrm{m}$ depth. There is a sharp contact between this zone and the underlying calcite carbonatite. The zone comprises of sandy weathering products, yellowish in colour.

iib) Upper portion of saprolite ( $4-5 \mathrm{~m}$ depth) was identified as a separate subzone. This is because it consists of more reddish material, perhaps reflecting the $\mathrm{Fe}$-content variations between the lower and upper saprolite.

iii) Colluvium forms the top $4 \mathrm{~m}$ of the profile. From $1-4 \mathrm{~m}$, the B2, this zone is characterized by reddish to reddish brown material, composed of rock fragments from $<2$ $\mathrm{cm}$ to $4 \mathrm{~cm}$ in diameter. The various rock types of the fragments lead to the conclusion that this and overlying material have been transported from higher slopes. From 0.7-0.3 $\mathrm{m}$, the $\mathrm{Bl}$, this zone contains a higher proportion of nodules and rock fragments than in the B2, above $0.3 \mathrm{~m}$ is a dark brown, nodular top soil. 
Depth

Description

(cm)

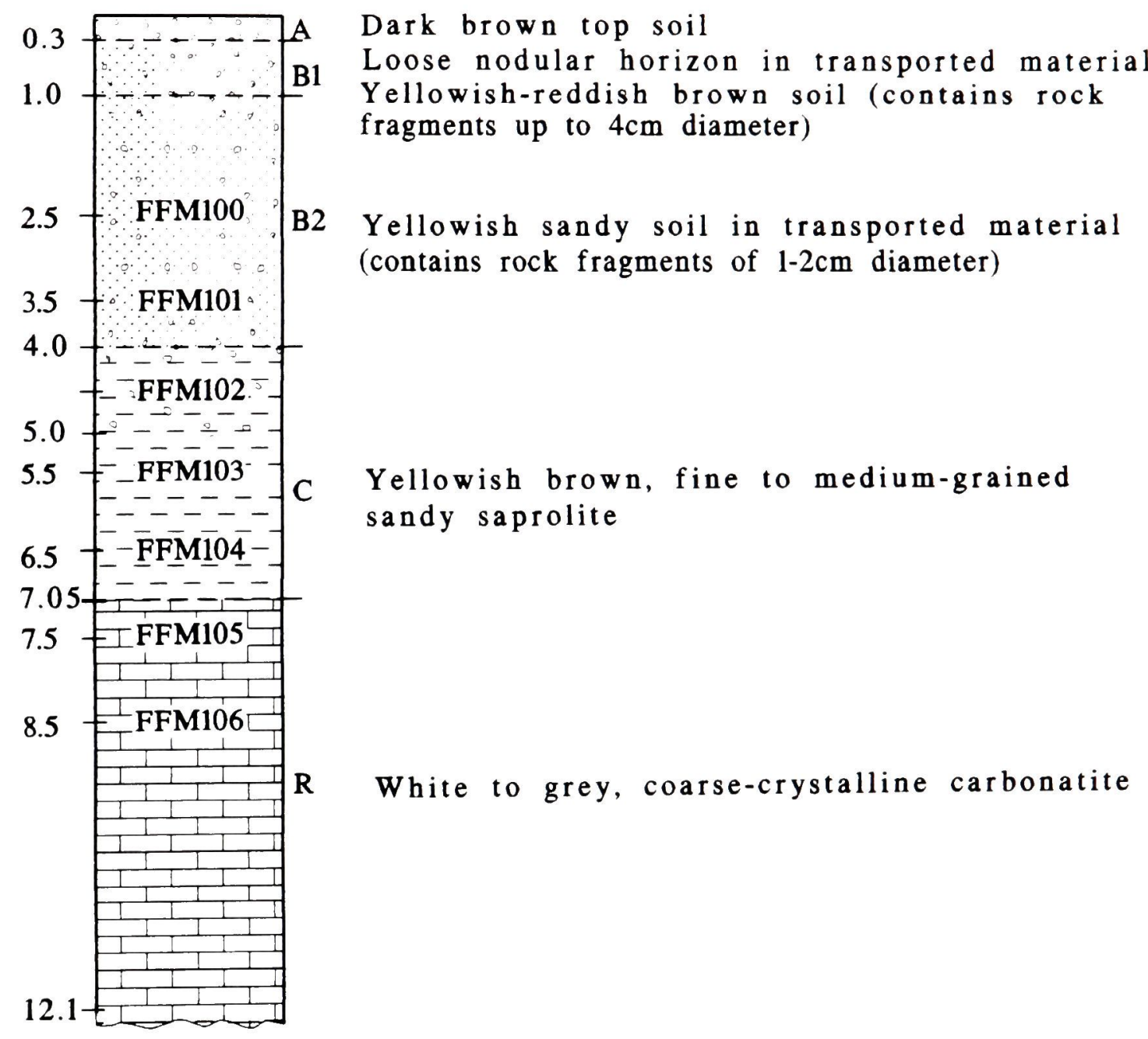

Fig. 4.3 Representation of lower-slope profile over Panda Hill carbonatite. (Locality of samples analyzed are identified) 


\subsubsection{Profile over apatite-magnetite mock}

The term "apatite-magnetite rock" has been used to describe a rock composition dominated by apatite and magnetite (van Straaten et al., 1992). Values of $\mathrm{P}_{2} \mathrm{O}_{5}$ for samples from this rock and the weathered material overlying it (pit 16) are, by far, the highest of values obtained from samples from Panda Hill. The average value for pit 16 is 19.0 wt. $\% \mathrm{P}_{2} \mathrm{O}_{5}$, whereas most other analyses have average values $<15 \% \mathrm{P}_{2} \mathrm{O}_{5}$.

Material from pit 16 was also used by members of the Agrogeology Project for production of phosphate concentrates for experiments and field trials (van Straaten et al., 1992). However, the rock is not extensive and occurs only in the form of late-stage veins (van Straaten, 1989). Residual materials overlying carbonatite have an advantage over apatite-magnetite rock with respect to tonnage.

This profile was not studied in detail because apatite-magnetite rock occurs as dykes, which are not common. A complete profile (Pit 16) above the apatite-magnetite rock from Panda Hill is described below:

i) Apatite-magnetite rock, at $>3 \mathrm{~m}$ depth. The rock is medium to coarse grained and contains vitreous, colourless apatite crystals and magnetite grains. Apatite and magnetite form the bulk of the minerals in this rock.

ii) Residual material (saprolite) rich in apatite and magnetite forms a zone 0.5-2 m thick. The material is generally medium-grained in the lower saprolite and finer in the upper portions of the saprolite. They are reddish-brown in colour.

iii) Transported materials form zones ranging from 2-4 m thick. They consist of fragments of various rock materials and reddish-brown soil. These are rich in apatite and magnetite. 
iv) The top soil is dark-brown and highly nodular.

\subsubsection{Profile over fenitized gneisses (Pit 30)}

Panda Hill carbonatite was intruded into Precambrian gneisses. Fenitizing fluids from the carbonatite invaded the gneisses to produce a K-feldspar-rich silicified rock. Unweathered fenite is pinkish in colour, and is harder than ordinary gneisses because of the high silica contents. The rock is very rich in apatite, and forms a shallow cover over some parts of the carbonatite. The weathering profile in this rock is similar to that developed above the apatite-magnetite rock. The residual materials overlying the fenitized gneiss are enriched in apatite, but the magnetite is relatively low. 


\section{CHAPTER 5 - WEATHERING OF PANDA HILL CARBONATITE}

\subsection{INTRODUCTION}

Chemical weathering at Panda Hill carbonatite was evaluated through a petrographic study of samples from the carbonatite and the products produced by weathering. Samples from the Agrogeology project drill hole number 6 were selected for the study because none of the pits at Panda Hill reached bedrock. Seven samples were chosen with material from each identifiable zone of weathering, starting from $1 \mathrm{~m}$ below the surface to the limit of drilling, in this case, $12 \mathrm{~m}$. In total, seven samples were studied, two representing carbonatite ( $>7 \mathrm{~m}$ ), three the residual material (saprolite, $4-7 \mathrm{~m}$ ) overlying the carbonatite, and two samples from the transported material over saprolite $(<4 \mathrm{~m})$. Transported materials (B-horizon) were included in the study, to assess any possible element or mineral concentration through processes other than residual accumulation.

Mchihiyo (1990) established that weathering of Panda Hill carbonatite proceeds with marked dissolution of carbonates accompanied by precipitation of hydrated oxides of $\mathrm{Fe}$ and $\mathrm{Al}$ and clay minerals. Mchihiyo also interpreted the higher apatite contents in the weathered materials than in primary rocks as evidence for a residual accumulation of apatite. Secondary phosphates of the crandallite group were identified in the weathering products from Panda Hill carbonatite (Mchihiyo, 1990).

The main objective of the current petrographic and geochemical study is to establish the type and distribution of primary and secondary minerals within successive zones of the weathering profile over the carbonatite, and identify zones of enrichment for phosphate minerals and REEs. To accomplish this, thin section examination was undertaken on 
samples from drill hole number 6 (DH6), which represents a weathering profile over carbonatite. Initial studies evaluated the modal mineralogy and textural features from thin sections using normal optical microscopy. This was done in order to establish the changes that occur in the rock materials and individual minerals as weathering proceeds.

Further examination of the products produced by weathering was carried out using scanning electron microscopy (SEM). Minerals, both primary and secondary, were identified. Properties which could not be identified under the optical microscope were determined. Generalized petrographic studies from microscopic studies are discussed in this section. The more detailed petrographic information is presented in Appendix C, Table C-1.

\subsection{OPTICAL MICROSCOPY}

\subsubsection{General description of samples}

A brief discussion of the samples selected for the petrographic study preceeds the petrographic descriptions in order to provide an overview of the type of materials which were dealt with in this study. Only those samples selected for petrographic and geochemical analyses are discussed in this section; the remaining samples are given in Appendix A, Table A-1. The drill hole from which the samples were obtained did not reach unweathered bedrock, so the carbonatite samples studied (samples FFM 105 and FFM106) are slightly to moderately weathered. Hand specimens were fractured and the fractures were found to be filled with reddish-brown alteration products, probably $\mathrm{Fe}$ oxides. The carbonatite is generally white, with medium- to coarse-crystalline texture. 
Moderately weathered samples are stained dark brown by the Fe-oxides.

Samples from the saprolite, or C-horizon (samples FFM104-102), from immediately above the carbonatite, are generally fine to medium grained and contain rock fragments. There is a gradational change in colour from yellow towards red and brown from the bottom of the saprolite towards the top, which is probably due to an increase in Fe-oxides. The material in the B-horizon (samples FFM101 and FFM100) is typically reddishbrown, and consists of magnetite and hematite and various rock fragments set in ferruginous soil. The uppermost $1 \mathrm{~m}$ of the profile consists of a $0.25 \mathrm{~m}$ to $0.30 \mathrm{~m}$ thick layer of dark-brown soil, rich in organic matter, and about $0.70 \mathrm{~m}$ of transported materials.

\subsubsection{Petrographic observations}

\subsubsection{Carbonatite $(7.05 \mathrm{~m}-12 \mathrm{~m})$}

Drill hole 6 did not reach "unweathered bedrock". Previous analyses for carbonatite samples indicate calcite contents up to $92 \%$ (van Straaten, 1989). The base of the studied section of the weathering profile consists of slightly-weathered carbonatite characterized by calcite, which forms $60 \%-75 \%$ (determined by point counting) by volume of the total composition. Carbonatite with this composition can be classified as calcite carbonatite (Wooley and Kempe, 1989).

Samples contain calcite enclosing accessory apatite, pyrochlore and magnetite. The calcite forms medium to coarse euhedral to subhedral crystals. Alteration products occur at the grain boundaries (Plate 5-A1). Crystal boundaries, cleavage planes and the original 
Plate 5-A1. Calcite, Cc, (rhombohedral crystals) in slightly weathered carbonatite. Secondary products are stained brown. Field of view $2.5 \mathrm{~mm}$, cross polarized light. Section from $8.5 \mathrm{~m}$ depth of profile. Sample FFM 106

Plate 5-A2. Secondary quartz $(\mathrm{Q})$ and Fe-oxides $(\mathrm{Fe})$ in fracture zones and voids in calcite. Field of view $2.5 \mathrm{~mm}$, cross-polarized light. Section from $7.5 \mathrm{~m}$ depth. Sample FFM 102. 


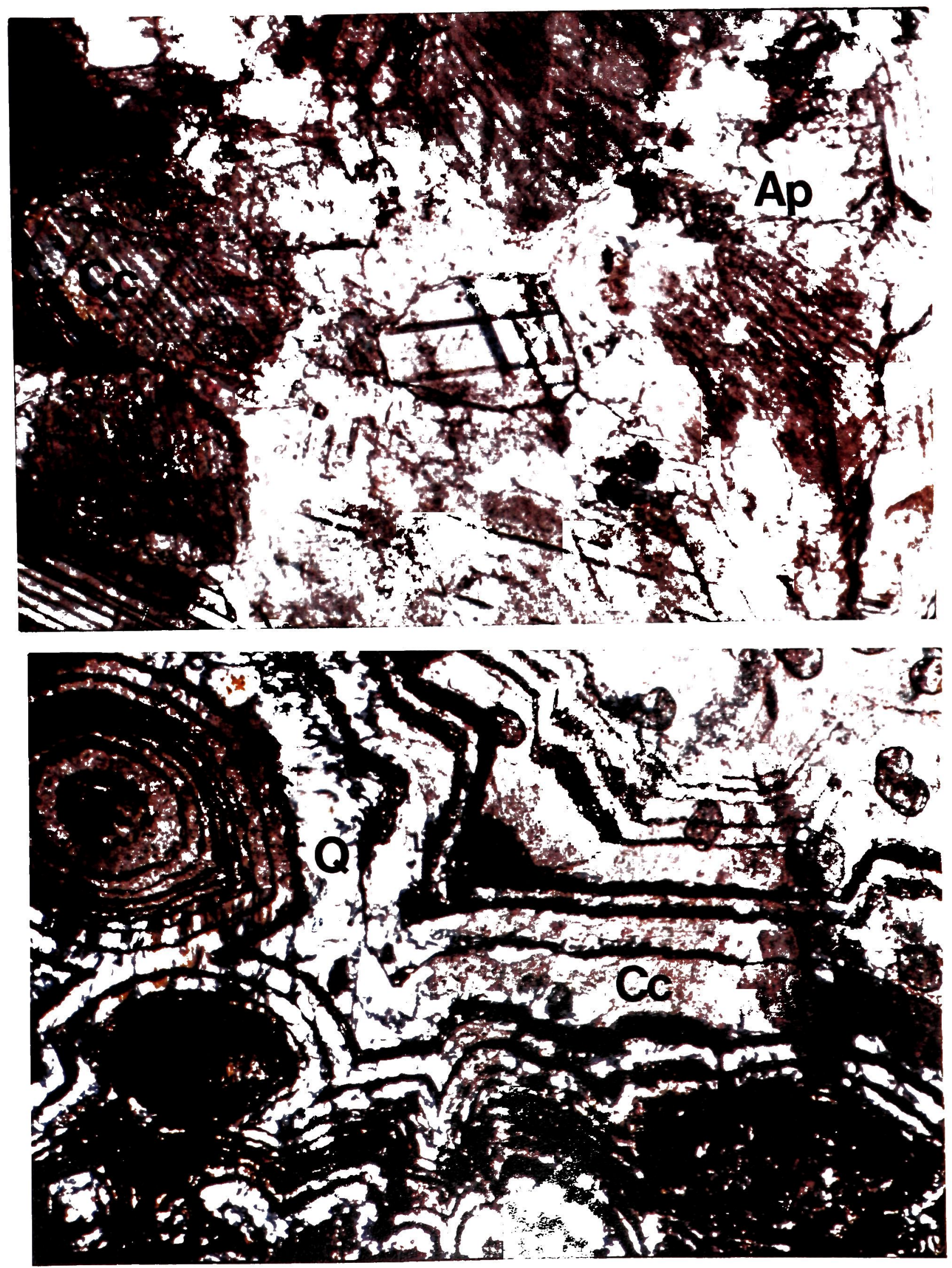


texture are still preserved in some crystals (e.g centre and left-hand side of plate 5-Al). Progressive dissolution of calcite is characterized by disappearance of the original rock texture and precipitation of Fe-oxides and secondary quartz in fracture zones and voids (Plate 5-A2). This is more pronounced in the moderately- weathered carbonatite where the original crystalline nature of the rock is destroyed and calcite composition decreases to $<50 \%$ as replacement by alteration products increases. The second most abundant mineral in the carbonatite samples is apatite, which forms an accessory mineral in all of the carbonatites studied in this work. Apatite forms about $5 \%$ to $8 \%$ by volume of the rock (determined by point counting). The mineral occurs in the form of euhedral to subhedral elongate crystals which commonly form cluster that, in places, show preferred orientations (Plate 5-A1 and 5-A3). The crystals are small, with an average size of $<0.5$ $\mathrm{mm}$, but some crystals can reach up to $1 \mathrm{~mm}$ in size. Early-stage alteration of apatite is indicated by breakdown of the original crystals and by alteration products that infill fractures. This effect is uncommon in apatite from slightly and moderately-weathered carbonatite, but is common in strongly-weathered carbonatite. This feature will be discussed later in this section.

The composition of the alteration products, which are mainly Fe-oxides, clay minerals and secondary quartz was determined by X-ray diffraction. The X-ray diffraction results are presented in Appendix C, Table C-3. 
Plate 5-A-3. A train of elongate crystals of apatite, Ap (white-pale blue), and magnetite (black) in calcite, Cc (pale pink). Dark stains reflect alteration products (pseudomorph after calcite at lower-left corner). Field of view $2.5 \mathrm{~mm}$, crosspolarized light. Section from $8.5 \mathrm{~m}$ depth. Sample FFM 106.

Plate 5-A4. Preserved apatite crystals in weathered material. Field of view $2.5 \mathrm{~mm}$, cross polarized light. Dark irregular patches are a mixture of goethite and hematite. Section from 5.5m depth. Sample FFM 103. 


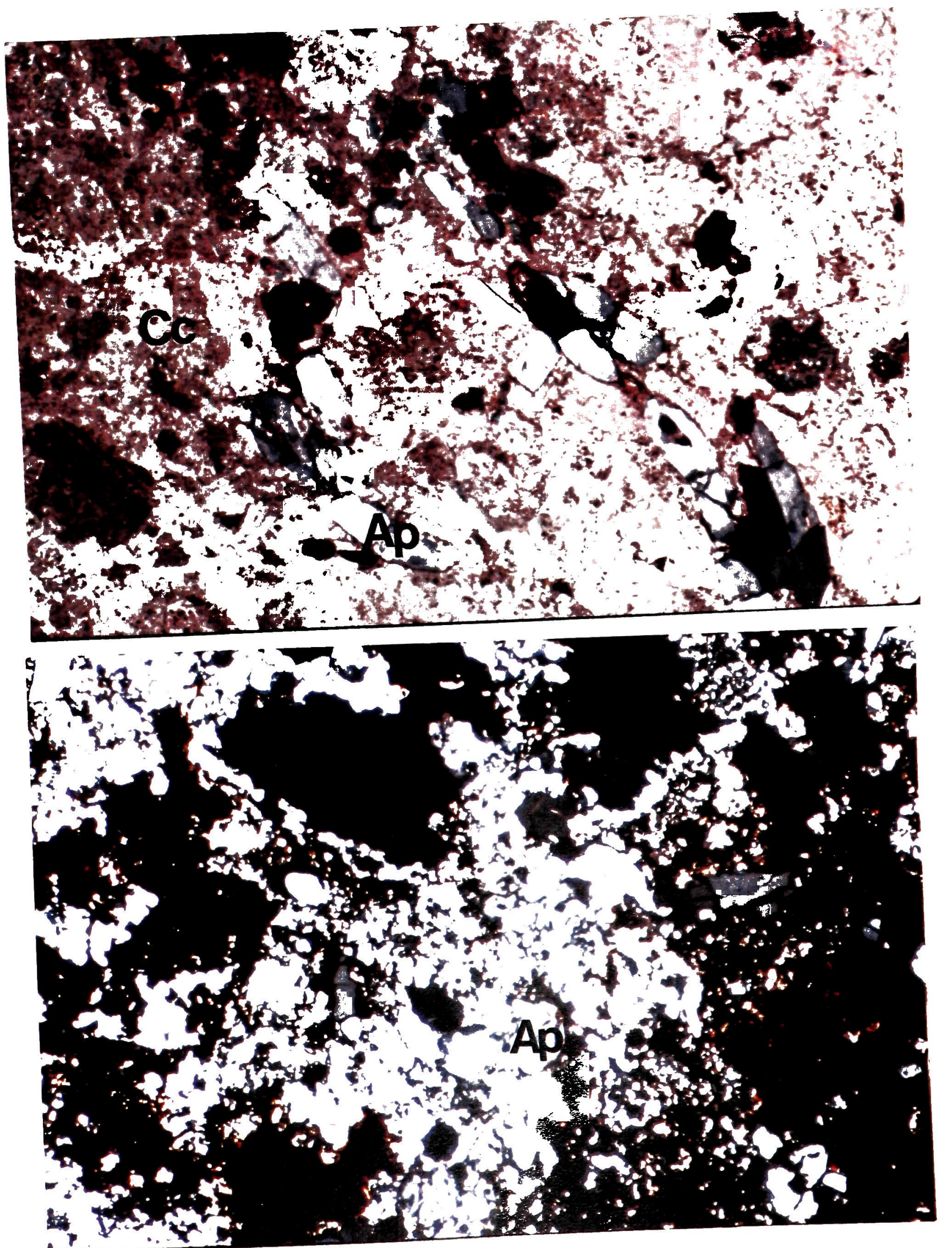




\subsubsection{Residual materials ( $4 \mathrm{~m}-7.05 \mathrm{~m}$ )}

Weathered materials that overlie the fresh Panda Hill carbonatite can be distinguished as "phosphate ore" formed by an apatite-rich residue and the transported materials above the ore. Samples from the residually-accumulated zone indicate an increase in calcite dissolution and its replacement by hydrated oxides of $\mathrm{Fe}$ and $\mathrm{Al}$, and clay minerals. Apatite forms up to $30 \%$ by volume of the weathered materials, but shows a variation in crystal form from the base to the top of the zone. Apatites in material about $1 \mathrm{~m}$ above the carbonatite still retain their original elongate form and euhedral shapes (Plate 5-A3). Progressive chemical weathering leads to the alteration of apatite crystals along fracture zones, producing smaller, ovoid to near sub-round apatite grains that lack distinctive crystal form (Plate 5-A4).

Apatite in the uppermost part of the residual material zone occurs as closely-packed, very fine grains. Some of the grains in these sections are mixed with secondary alteration products. Plate 5-A5 shows secondary $\mathrm{Fe}$ and $\mathrm{Al}$ oxides in fracture zones in apatite.

\subsubsection{Transported Materials (2m $-5 \mathrm{~m})$}

Sections from the middle and lower parts of the zone overlying the residual materials indicate increased concentrations of fresh and slightly altered apatite set in a ferruginous matrix (Plate 5.A6). Apatite occurs together with nodules of hematite and magnetite and fragments of various rock material. The apatite crystals were probably transported to the DH6 site from the upper slopes of the complex, where apatite-rich fenitized gneiss and apatite-magnetite rocks are located (Fig.2.2) 
Plate 5-A5. Fe-oxides(yellow-red) in fractures in apatite crystals (Ap). Cross polarized light. Field of view $5 \mathrm{~mm}$. Section from 5.5m depth. Samle FFM 103.

Plate 5-A6. Transported apatite grains. Note the shape of apatite crystals. Some are rounded, others are angular. Rock fragments $(R)$ can be seen in the hand specimen. Matrix material (yellowish-red) is ferruginous. Field of view $2.5 \mathrm{~mm}$, cross polarized light. Section from $2.5 \mathrm{~m}$ depth. Samlpe FFM 100. 

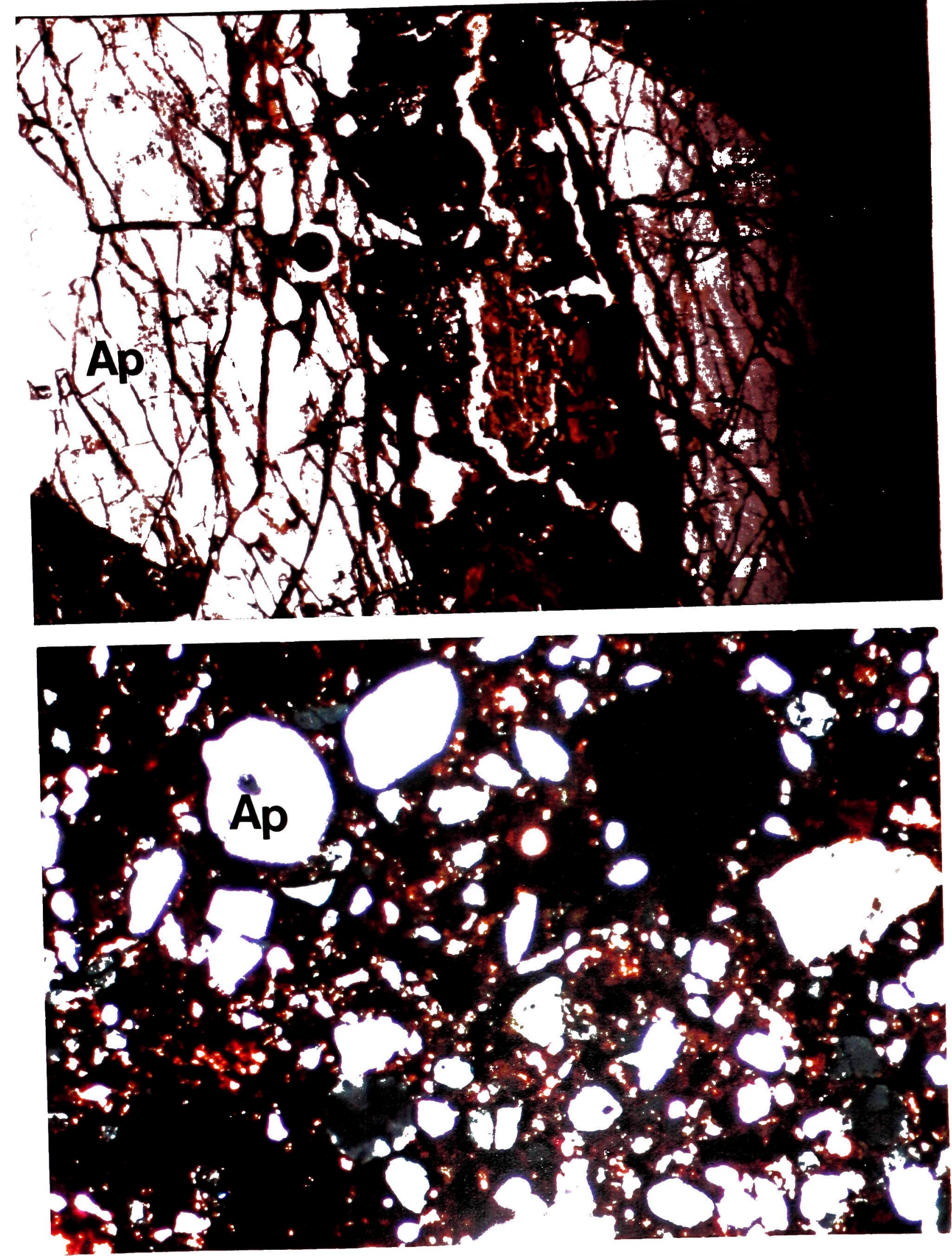


\subsubsection{Discussion}

Examination of the thin sections shows that chemical processes are mainly responsible for weathering of the rocks at Panda Hill. The profile that was studied from drill hole number 6 shows distinctive changes in composition and modal distribution of minerals as weathering proceeds. Table 5-1 summarizes the modal distribution of minerals in the weathering profile overlying the Panda Hill carbonatite.

Table 5-1: Mineral phases in profile over Panda Hill carbonatite

\begin{tabular}{||l|l|l|l||}
\hline Mineral & $\begin{array}{l}\text { Carbonatite } \\
\text { (from van } \\
\text { Straaten,1989) }\end{array}$ & $\begin{array}{l}\text { Slightly weath-ered } \\
\text { carbonatite (DH6) }\end{array}$ & $\begin{array}{l}\text { Residual } \\
\text { materials } \\
\text { (DH6) }\end{array}$ \\
\hline Calcite & up to 92\% & $60-75 \%$ & $<30 \%$ \\
\hline Dolomite & $<5 \%$ & - & - \\
\hline Apatite & $5-8 \%$ & $5-8 \%$ & $25-45 \%$ \\
\hline Pyrochlore & $5 \%$ & $5 \%$ & $5 \%$ \\
\hline Magnetite & $3-10 \%$ & $3-5 \%$ & $5 \%$ \\
\hline $\begin{array}{l}\text { Goethite+ } \\
\text { quartz }\end{array}$ & - & $10-25 \%$ & $30 \%-45 \%$ \\
\hline
\end{tabular}

Calcite is abundant in the carbonatite samples, but decreases in the weathered materials. Apatite increases in concentration and decreases in grain size in the weathered materials, although some grains appear to be only slightly affected. The concentration of secondary Fe-oxides and quartz on the other hand increases as calcite decreases, and they form up to $50 \%$ by volume of the strongly-weathered materials. 


\subsection{Scanning Electron Microscopy}

\subsubsection{Introduction}

Carbon-coated thin sections were examined with a JEOL, JSM-6400, scanning electron microscope (SEM) connected to an energy-dispersive X-ray analytical system (Pentafet Link Analytical). Working conditions were $20-\mathrm{kV}$ accelerating voltage, 8-nA beam current and $100 \mathrm{~s}-180$ s counting time for individual spectra.

Morphological changes on individual mineral crystals and mineral proportions (grain counting) were determined by the back-scattered electron (BSE) mode. Compositions were obtained using energy-dispersive spectra. A general discussion of the results is given below, accompanied by selected chemical data. Results for all analyses are presented in Appendix C, Table C-2.

\subsubsection{Analytical Results}

Scanning electron microscopy allowed the identification of minerals which could not be easily distinguished under the optical microscope. The most important feature to emerge from this study is the presence of secondary phosphates of various composition. The phosphates occur as fine-grained, closely-packed clusters associated with the altered parts of the apatite crystals, or as independent micro-crystals enclosed in quartz. Other minerals that were identified are fluorocarbonate, barite, pyrochlore and Fe-oxides and quartz. The discussion presented here specifically deals with the phosphate minerals and fluorocarbonate, a rare-earth mineral. Other minerals are discussed briefly, and their chemical compositions are included in Appendix C, Table C-2. 


\subsubsection{Apatite}

The presence of apatite in the Panda Hill profile was supported by the elemental compositions obtained. The main apatite mineral is fluorapatite $\left[\mathrm{Ca}_{5}\left(\mathrm{PO}_{4}\right)_{3} \mathrm{~F}\right]$. Table 5-2 presents selected elemental compositions for apatite from the studied sections.

Table 5-2: Selected analyses of apatite (n.a: not analysed)

\begin{tabular}{|l|l|l|l|l|l|l|l|l|l|l|l|l||}
\hline \hline $\mathrm{CaO}$ & 53.53 & 50.27 & 51.47 & 51.43 & 53.48 & 52.90 & 54.29 & 52.58 & 53.61 & 51.76 & 55.01 & 51.0 \\
\hline $\mathrm{P}_{2} \mathrm{O}_{5}$ & 42.41 & 40.94 & 41.60 & 41.27 & 42.26 & 37.50 & 42.64 & 40.69 & 41.22 & 37.19 & 40.76 & 40.2 \\
\hline $\mathrm{F}$ & $\mathrm{n} . \mathrm{a}$ & 2.80 & 2.97 & 2.58 & n.a & n.a & n.a & 2.87 & 3.02 & 2.65 & 3.10 & 3.40 \\
\hline $\mathrm{Sr}$ & 1.02 & 1.25 & 1.63 & 0.54 & 0.76 & 0.65 & 0.72 & 1.15 & 0.83 & 0.91 & 0.52 & 4.72 \\
\hline $\mathrm{FeO}$ & 0.17 & 0.29 & 0.49 & 0.00 & 0.16 & 0.40 & 0.00 & 0.04 & 0.02 & 0.09 & 0.03 & 0.40 \\
\hline
\end{tabular}

1-7. Fluorapatite, Panda Hill, Tanzania (current study); 8-9. Fluorapatite, Panda Hill,

Tanzania (Mchihiyo, 1990); 10. Fluorapatite, Oka, Quebec (Hogarth, 1989); 11. Fluorapatite,

Rangwa, Kenya (Hogarth, 1989);12. Strontian fluorapatite, Nkombwa, Zambia (Hogarth, 1989)

The table includes data from previous analyses of apatites from Panda Hill (Mchihiyo, 1990) and from some non-Tanzanian localities (Hogarth, 1989).

There is excellent agreement between the analyses carried out in this work and the analyses given by Mchihiyo (1990). The main differences are in the total FeO contents. Most of the apatite analyses obtained by this work have higher $\mathrm{FeO}$ contents, except for analyses from samples FFM103 and FFM 106. Fluorapatites from other carbonatites quoted by Hogarth (1989) have similar compositions. 
Apatite was found in all sections of the profile, and is present as elongate crystals (Plate 5-B1). The apatite crystals that are slightly altered contain secondary alteration products along crystal boundaries and in fractures. The lower part of the the saprolite contains crystals with apatite overgrowths that indicate alteration proceed from the surface towards the centre of the crystals. A core of fluorapatite is surrounded by a rim of secondary phosphates (Plate 5-B2).

Strongly-altered apatite crystals are either partly replaced or coated by secondary phosphates. Partial replacement of apatite crystals is indicated by the the relict areas within the original apatite grains (Plate 5-B3). The fine crystals are of secondary phosphates. Quartz forms the matrix for the fine crystals and also fills voids and microfractures on apatite.

\subsubsection{Fluorocarbonate}

Fluorocarbonates are rare-earth minerals found in carbonatites. The common fluorocarbonates are bastnaesite $\left[(\mathrm{REE}) \mathrm{CO}_{3} \mathrm{~F}\right]$, parisite $\left[\mathrm{Ca}(\mathrm{REE})_{2}\left(\mathrm{CO}_{3}\right)_{3} \mathrm{~F}_{2}\right]$, synchysite $\left[\mathrm{Ca}(\mathrm{REE})\left(\mathrm{CO}_{3}\right)_{2} \mathrm{~F}\right]$ and ancylite $\left[\mathrm{Sr}(\mathrm{REE})\left(\mathrm{CO}_{3}\right)_{2}(\mathrm{OH}) \cdot \mathrm{H}_{2} \mathrm{O}\right]$ (Kapustin, 1980; Mariano, 1989b; Ni et al., 1993). Primary REE minerals are usually not found in early stage carbonatites, but occur as products of late-stage magmatic, and hydrothermal activity (Mariano, 1989a,b). Mariano argued that the fluids which permeate fractures in carbonatite become enriched in $\mathrm{Ba}, \mathrm{F}, \mathrm{SO}_{4}{ }^{2-}, \mathrm{Sr}$, REEs, and $\mathrm{Th}$, obtained from dissolving primary carbonates. The REEs react with the $\mathrm{CO}_{3}^{2-}$ ions in solution to form fluorocarbonates; in the presence of $\mathrm{PO}_{4}{ }^{3-}$, $\mathrm{REE}$ phosphate (i.e monazite) are preferentially formed (Mariano, 1989a,b). 
Plate 5-B1. Electron backscatter photomicrograph showing elongate, prismatic crystals of apatite (Ap) and magnetite (black) in calcite (Cc). Section from $8.5 \mathrm{~m}$ depth. Scale bar $6 \mathrm{~mm}$. Sample FFM 106.

Plate 5-B2. Electron backscatter photomicrograph showing apatite crystals from the lower portion of saprolite. Ap denotes apatites and Sp of secondary phosphates. Dark (M) regions represent the matrix composed of a mixture of quartz and $\mathrm{Al}$ and $\mathrm{Fe}$ oxide. Section from $6.5 \mathrm{~m}$ depth. Scale bar $6 \mathrm{~mm}$. Sample FFM 104. 

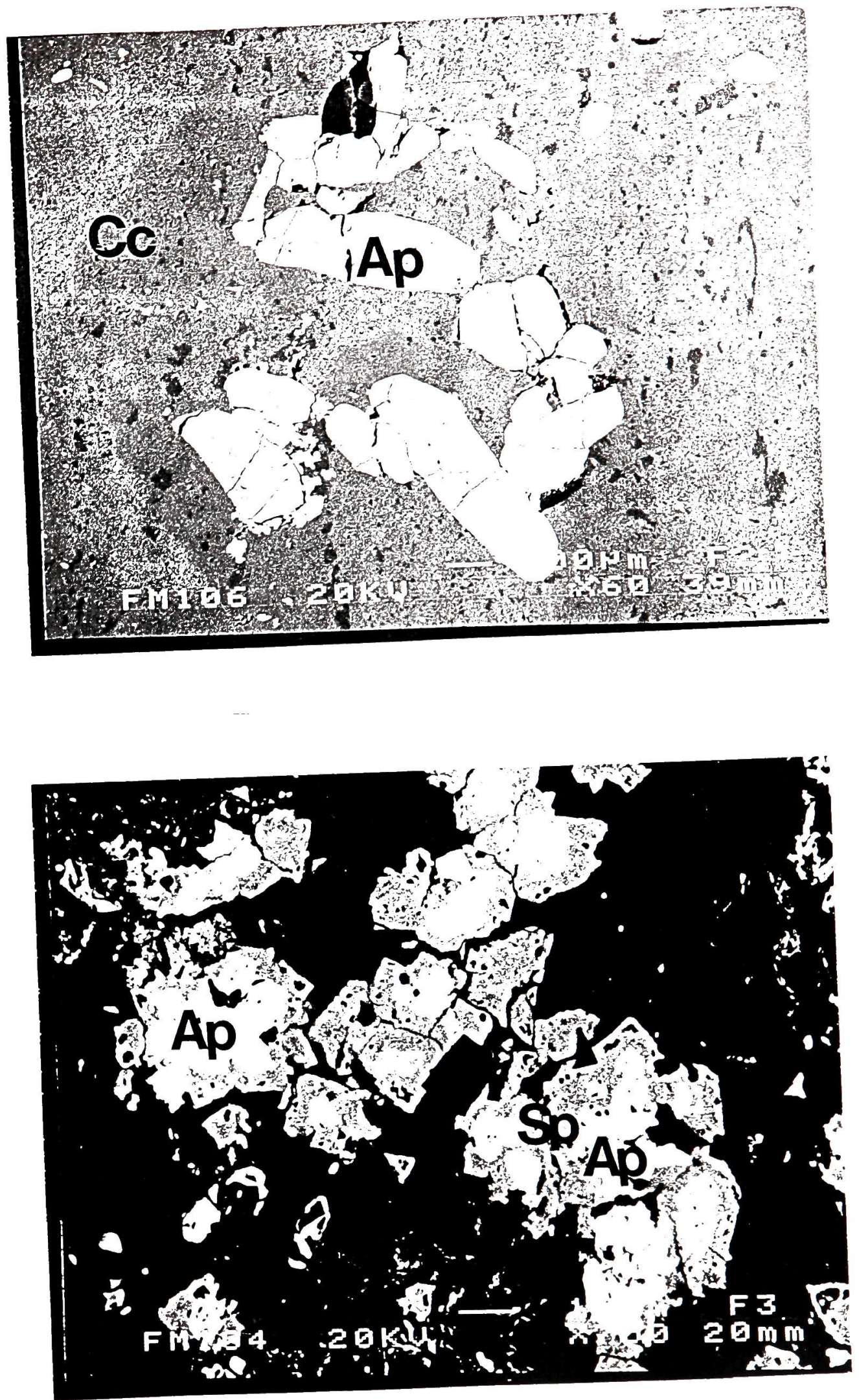
Plate 5-B3: Electron backscatter photomicrograph showing altered apatite (Ap) and secondary phosphate minerals (Sp). Dark regions (M) represent matrix minerals. Scale bar $6.5 \mathrm{~mm}$. Section from $4.5 \mathrm{~m}$ depth. Sample FFM 102. 


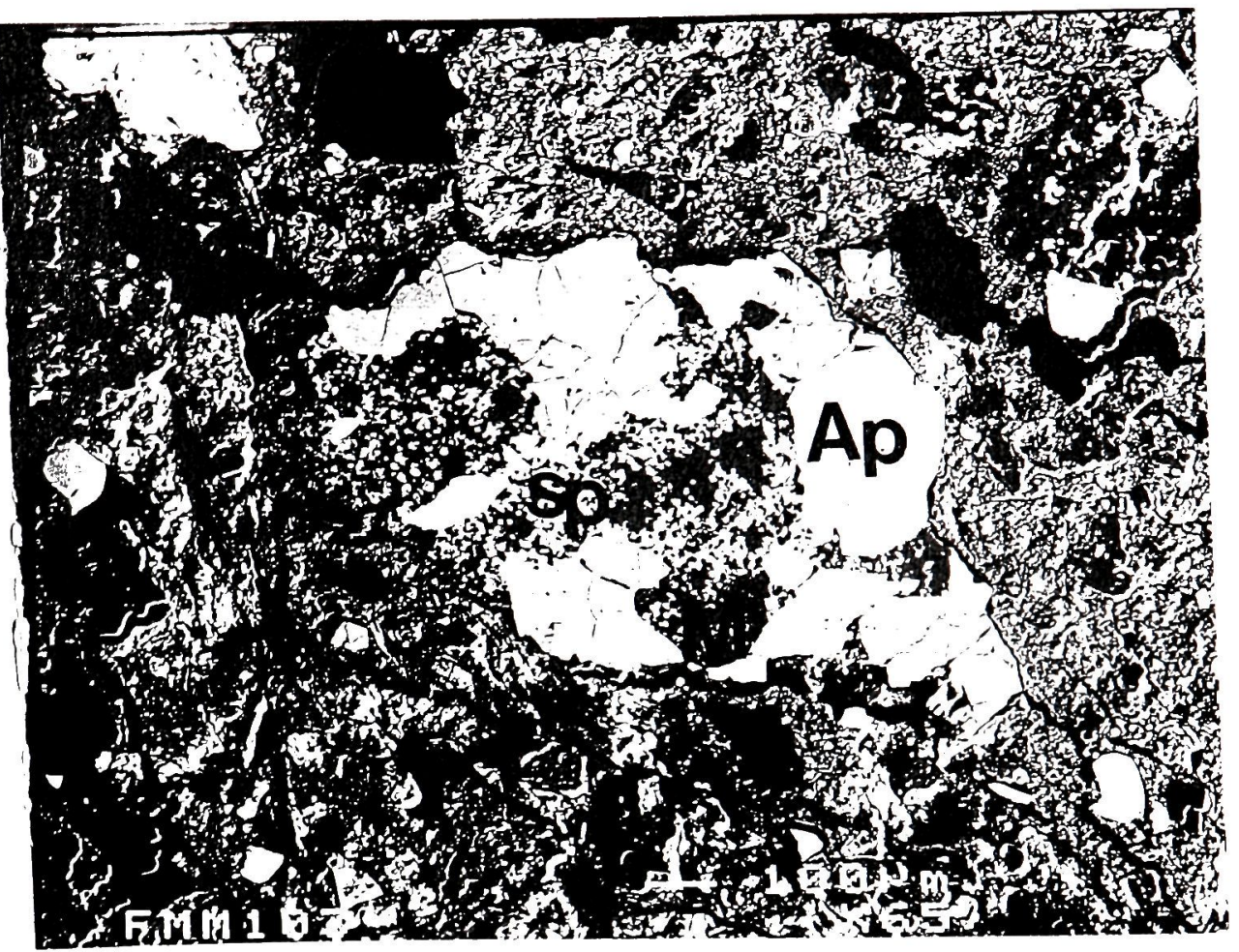


Results from the current study indicate the occurrence of fluorocarbonate in the carbonatite samples (FFM 106) but not in the weathered materials. This is consistent with the presence of unaltered apatite and the subsequent unavailability of free $\mathrm{PO}_{4}{ }^{3-}$ ions in the relatively unweathered carbonatite, which favours the precipitation of REE carbonates. The composition (wt \% oxides) for the fluorocarbonate mineral from the Panda Hill carbonatite is: $\mathrm{CaO}=20.08 ; \mathrm{La}_{2} \mathrm{O}_{3}=11.66 ; \mathrm{Ce}_{2} \mathrm{O}_{3}=24.21 ; \operatorname{Pr}_{2} \mathrm{O}_{3}=2.19$; and $\mathrm{Nd}_{2} \mathrm{O}_{3}=8.20$. This composition approaches that of synchysite, which theoretically contains $52.64 \%$ total $\mathrm{RE}_{2} \mathrm{O}_{3}[(\mathrm{La}+\mathrm{Ce}+\mathrm{Pr}+\mathrm{Nd})]$ [Mariano, 1989b].

\subsubsection{Secondary Phosphate Minerals}

Residual materials over Panda Hill carbonatite contain secondary phosphate minerals formed by alteration of primary apatite, followed by reprecipitation elsewhere in the weathering profile. The minerals show variations in elemental compositions, depending on the conditions and availability of the free elements available for reactions. The elements are mainly redistributed by ground water and redeposited in fracture zones or veinlets and along mineral boundaries. The elements released from primary carbonatite minerals other than apatite are mainly REEs, Ba, Sr and Th (Mariano, 1989a). Primary apatite alteration is accompanied by the release of $\mathrm{PO}_{4}{ }^{3-}$ and REEs. The apatite structure also allows isomorphous substitution of $\mathrm{REE}^{3+}, \mathrm{Ba}^{2+}$, or $\mathrm{Sr}^{2+}$ for $\mathrm{Ca}^{2+}, \mathrm{SO}_{4}{ }^{2-}$ and $\mathrm{CO}_{3}{ }^{2-}$ for $\mathrm{PO}_{4}{ }^{3}$, and $\mathrm{Cl}^{-}$and $\mathrm{OH}^{-}$for $\mathrm{F}^{-}$. When the trivalent $\mathrm{REE}$ ion substitutes for $\mathrm{Ca}^{2+}$, the charge deficit is compensated by a monovalent ion, commonly $\mathrm{Na}^{+}$. The structure of apatite is discussed in detail by Hogarth (1989).

Secondary phosphates found within the contact zone between saprolite and carbonatite 
are mostly REE-, Ba- and Sr-bearing. Secondary phosphates in the upper parts of the profile include $\mathrm{Al}$ and $\mathrm{Fe}$ bearing varieties, probably due to the introduction of $\mathrm{Al}$ and Fe from the country rocks. The minerals are generally very small, with sizes in the order of less than one micron. However, morphological features are the same as for apatite, i.e. they occur in rhombohedral forms as euhedral to subhedral crystals. The secondary phosphates found in this work are discussed under three main groups, the REE phosphates, the crandallite group minerals and the aluminum phosphate-sulphates.

\section{i) REE phosphates}

The common REE phosphate mineral from carbonatites is monazite, $(\mathrm{Ce}, \mathrm{La}) \mathrm{PO}_{4}$, which may exist as a primary mineral or as a secondary mineral formed by the reaction of REE and $\mathrm{PO} 4$ from altered primary minerals. Rhabdophane $\left[(\mathrm{Ce}, \mathrm{La}) \mathrm{PO}_{4} \cdot \mathrm{H}_{2} \mathrm{O}\right]$ is a secondary REE phosphate formed by weathering of REE minerals such as fluoracarbonates in an aqueous system (Clark, 1984). Two varieties of rhabdophane are known, one enriched in La and the other in Ce (Mariano, 1989b). Minor contents of rhabdophane were identified in materials from Panda Hill. The elemental composition (wt \% oxide) obtained for this mineral is: $\mathrm{P}_{2} \mathrm{O}_{5}=27.79 ; \mathrm{La}_{2} \mathrm{O}_{3}=15.33 ; \mathrm{Ce}_{2} \mathrm{O}_{3}=34.41 ; \operatorname{Pr}_{2} \mathrm{O}_{3}=3.18$; and $\mathrm{Nd}_{2} \mathrm{O}_{3}=11.6$. This has been specified as rhabdophane-(Ce) following the accepted standard of denoting the element with greatest weight percentage in parentheses (Bayliss and Levinson, 1988; Mariano, 1989b). 


\section{ii) Crandallite group minerals}

The minerals forming the crandallite group are florencite $\left[(\mathrm{REE}) \mathrm{Al}_{3}\left(\mathrm{PO}_{4}\right)_{2}(\mathrm{OH})_{6}\right]$, gorceixite $\left[(\mathrm{Ba}, \mathrm{REE}) \mathrm{Al}_{3}\left(\mathrm{PO}_{4}\right)_{2}\right]$, goyazite $\left[(\mathrm{Sr}, \mathrm{Ca}) \mathrm{Al}_{3}\left(\mathrm{PO}_{4}\right)_{2}(\mathrm{OH})_{5} \cdot \mathrm{H}_{2} \mathrm{O}\right]$ and crandallite $\left[\mathrm{CaAl}_{3}\left(\mathrm{PO}_{4}\right)_{2}(\mathrm{OH})_{5} \cdot \mathrm{H}_{2} \mathrm{O}\right]$. Goyazite is the most abundant crandallite-group mineral found in the residual materials over Panda Hill carbonatite. Other minerals found have compositions between goyazite and gorceixite, and some approach that of florencite. Selected analyses are presented in Table 5-3.

\section{iii) Aluminum phosphate-sulphates (APS minerals)}

Large amounts of complex phosphate minerals containing $\mathrm{SO}_{4}{ }^{2-}$ were identified in the residual materials. The minerals are chemically close to those studied and identified by Spotl (1990) in sandstones of the Mitterberg Formation, Austria. Spotl regarded the minerals as solid solutions between woodhousite $\left[\mathrm{CaAl}_{3}\left(\mathrm{SO}_{4}\right)\left(\mathrm{PO}_{4}\right)(\mathrm{OH})_{6}\right]$, svanbergite $\left[\mathrm{SrAl}_{3}\left(\mathrm{SO}_{4}\right)\left(\mathrm{PO}_{4}\right)(\mathrm{OH})_{6}\right]$, crandallite and goyazite. According to Spotl, the minerals can be assigned to the alunite-jarosite family, characterized by the general formula $\mathrm{AB}_{3}\left(\mathrm{XO}_{4}\right)_{2}(\mathrm{OH})_{6}$, where sites $\mathrm{A}$ can be occupied by $\mathrm{Na}^{+}, \mathrm{K}^{+}, \mathrm{Ca}^{+}, \mathrm{Pb}^{2+}, \mathrm{Ba}^{2+}$ or $\mathrm{Sr}^{2+}$. The B site can be occupied by $\mathrm{Al}^{3+}, \mathrm{Cu}^{2+}$ or $\mathrm{Zn}^{2+}$, while $\left(\mathrm{XO}_{4}\right)$ can be $\mathrm{PO}_{4}{ }^{3 \cdot}, \mathrm{SO}_{4}{ }^{2-}$ or $\mathrm{AsO}_{4}{ }^{2 \cdot}$. Spotl proposed that these minerals are formed by precipitation following the dissolution of apatite in low-pH environments. He mentions that these minerals are also reported from profiles of tropical soils.

Elemental compositions obtained from the Panda Hill residual material (Table 5-3) indicate svanbergite as the dominant APS mineral in the material from above the carbonatite. 
Sample FFM 104, which represents the profile section closest to the contact between weathered material and carbonatite, indicates traces of $\mathrm{Ca}$ in the minerals. These minerals with $\mathrm{Ca}$ in the structure are very close to svanbergite in composition.

Table 5-3: Elemental compositions of secondary phosphates in weathered materials over Panda Hill carbonatite

a) Crandallite minerals

12

$\mathrm{Al}_{2} \mathrm{O}_{3} \quad 20.25 \quad 25.09$

$\begin{array}{lll}\mathrm{Fe}_{2} \mathrm{O} 3 & 0.41 & 0.28\end{array}$

$\mathrm{P}_{2} \mathrm{O}_{5} \quad 18.47 \quad 22.44$

$\mathrm{SrO} \quad 7.05 \quad 9.87$

$\mathrm{SO} 3 \quad 0.82 \quad 1.60$

$\begin{array}{lll}\mathrm{CaO} & 0.38 & 0.14\end{array}$

$\mathrm{BaO} \quad 0.00 \quad 0.00$

$\mathrm{La}_{2} \mathrm{O}_{3} \quad 2.39 \quad 2.88$

$\mathrm{Ce}_{2} \mathrm{O}_{3} \quad 5.02 \quad 5.54$

$\begin{array}{lll}\mathrm{Pr}_{2} \mathrm{O}_{3} & 0.00 & 0.70\end{array}$

$\begin{array}{lll}\mathrm{Nd}_{2} \mathrm{O} 3 & 1.07 & 0.32\end{array}$ b) Aluminum phosphatesulphates

$\begin{array}{lll}1 & 2 & 3\end{array}$

$31.33 \quad 31.39$

$0.83 \quad 0.95$

$23.77 \quad 24.28$

$18.37 \quad 17.84$

$5.49 \quad 5.31$

$0.76 \quad 0.60$

$1.10 \quad 0.00$

$0.00 \quad 1.25$

$0.11 \quad 2.19$

$0.51 \quad 0.00$

$1.27 \quad 0.66$
29.77

1.49

24.11

16.51

3.09

0.38

2.50

0.00

1.37

0.85

0.55

\subsubsection{Matrix minerals}

The matrix mineral is calcite for the carbonatite samples, while Fe-oxides (mainly goethite and hematite), kaolinite and quartz form the matrix in the weathered materials. In saprolite, fine aggregates of secondary phosphates are intergrown with other minerals in the matrix. The minerals were identified from the chemical compositions obtained from the SEM and from XRD patterns. The proportions of matrix minerals vary from sample to sample. A discussion of the proportions of $\mathrm{Fe}, \mathrm{Al}$ and $\mathrm{Si}$ are given in Chapter 6 . 
Selected compositions of two identified Fe-oxides are given below:

$\begin{array}{llllll}\mathrm{SiO}_{2} & \mathrm{Al}_{2} \mathrm{O}_{3} & \mathrm{FeO} & \mathrm{MgO} & \mathrm{MnO} & \mathrm{CaO}\end{array}$

$\begin{array}{llllll}3.37 & 2.82 & 69.36 & 0.46 & 0.49 & 0.36\end{array}$

$\begin{array}{llllll}3.45 & 0.95 & 71.95 & 0.51 & 0 & 0.64\end{array}$

Quartz is found intermixed with the Fe-oxides in the matrix because of $\mathrm{SiO}_{2}$ values from altered parts of the matrix. Because $\mathrm{SiO}_{2}$ is more abundant in the saprolite and upper parts of the profile, it may be transported from the surrounding country rocks.

\subsubsection{Pyrochlore}

Pyrochlore is a common accessory mineral in carbonatites. When present, pyrochlore can contain significant contents of REEs and other trace elements (Hogarth, 1989; Mariano, 1989; Wyllie, 1989). Pyrochlore can concentrate in Fe-rich residual materials over some carbonatites (Hogarth, 1989). Alteration of pyrochlore is accompanied by enrichments in $\mathrm{La}, \mathrm{Nb}, \mathrm{Ta}, \mathrm{Th}$, etc., and with progressive weathering pyrochlore may form a mixture of oxides, including $\mathrm{La}_{2} \mathrm{O}_{3}$ (Hogarth, 1989). Because pyrochlore is a possible donor of rare earth and trace elements to a weathering system, it plays a role in the formation of secondary REE-bearing minerals. Pyrochlore has been identified in the samples from Panda Hill, particularly in the carbonatite samples and in saprolite. Elemental compositions of the pyrochlore minerals found in the Panda materials indicate that the pyrochlore is of a Sr-rich, Nb-bearing and Ti-bearing variety, with $\mathrm{Nb}_{2} \mathrm{O}_{5}=66.9 \mathrm{l}$ (pyrochlore), and $\mathrm{TiO}_{2}=45.57$ (betafite). High contents of $\mathrm{Fe}$ are associated with betafite from the upper saprolite, probably due to intermixing with matrix iron oxides. 
A sample from the upper saprolite also contains a mineral with a high manganese content (49.72 wt $\%$ oxide). Other elements contained in this mineral are $\mathrm{Fe}_{2} \mathrm{O}_{3}=14.63$, $\mathrm{BaO}=12.02, \mathrm{CaO}=1.54$ and $\mathrm{MgO}=0.19$. This composition best fits the mineral columbite [(Fe,Mn) $\left.\mathrm{Nb}_{2} \mathrm{O}_{6}\right]$ (Kapustin, 1980). According to Mariano (1989a), ferrocolumbite from carbonatites generally contain very low $\mathrm{Ta}$ and $\mathrm{Mn}$.

\subsubsection{Discussion}

Weathering of Panda Hill carbonatite is accompanied by changes in the primary mineral morphology and chemistry. Calcite, the most soluble primary mineral in the Panda Hill carbonatite, becomes minor in abundance in the upper parts of the profile. However, the $\mathrm{Ca}^{2+}$ and $\mathrm{CO}_{3}{ }^{2-}$ ions and REEs released from calcite, have been involved in the formation of secondary calcite and REE carbonates.

Apatite is the most common accessory mineral in carbonatites. The mineral is highly resistant to weathering and has persisted in the weathering profile. However, some apatite crystals in the saprolite have disintegrated into polycrystalline aggregates. This has led to an increased attack by percolating groundwater charged with various elements, which has allowed the formation of different secondary phosphate minerals. The identified secondary phosphates were formed through substitution of REEs, $\mathrm{Ba}, \mathrm{Sr}$ and $\mathrm{Al}$ for $\mathrm{Ca}^{2+}$ in the apatite structure. Phosphate ions released from apatite react mainly with REEs to form monazite, which is altered to rhabdophane. Aluminum phosphate sulphates, e.g. svanbergite, are probably second degree secondary products, formed as $\mathrm{SO}_{4}{ }^{2-}$ substitutes for $\mathrm{PO}_{4}{ }^{3-}$ in the first-degree secondary phosphates containing $\mathrm{Ba}$ and $\mathrm{Sr}$. 
Pyrochlore behaves similarly to apatite, by participating in the formation of secondary minerals in the weathering profile at Panda Hill. Alteration of pyrochlore leads to enrichment of, among other elements, LREEs in aqueous solutions, which can react with phosphate to form secondary phosphates. 


\section{CHAPTER 6 - GEOCHEMISTRY OF PANDA HILL CARBONATITES}

\subsection{Introduction}

The objective for the geochemical study of the Panda Hill material was to examine the behaviour of major, minor, trace and rare earth elements during weathering. The study involved quantitative analyses of major and minor elements by $\mathrm{X}$-ray fluorescence (XRF) at the University of Ottawa, and trace and REE analyses by XRF and inductively coupled plasma mass spectrometry (ICP-MS) at Memorial University of Newfoundland.

During digestion, it was found that multiple-acids ( $\mathrm{HF}$ and $\mathrm{HNO}_{3}$ followed by $\mathrm{HCl} / \mathrm{HNO}_{3}$ ) did not dissolve all of the sample, and that a white insoluble residue was obtained for all the samples other than FFM106. Because many of the samples contain pyrochlore, which is an extremely difficult mineral to dissolve, the samples were sintered using sodium peroxide $\left(\mathrm{Na}_{2} \mathrm{O}_{2}\right)$ and reanalysed.

Analysis of major elements at the University of Ottawa was done by $\mathrm{Li}_{2} \mathrm{~B}_{4} \mathrm{O}_{7} / \mathrm{LiBO}_{2}$ fused glass beads. Some samples with high Fe contents were diluted with pure silica to reduce the elemental abundances to levels that fall within the limits set by the analytical standards.

\subsection{Analytical Results}

A comparison of the trace and REE chemical data from the $\mathrm{HF}-\mathrm{HNO}_{3} / \mathrm{HCl}-\mathrm{HNO}_{3}$ treatment with the values from the sintered samples are shown in Table 6.1. For most of the elements the values are the same using both techniques. The data, however, shows significant discrepancies for $\mathrm{Nb}$, which was expected, and small discrepancies for $\mathrm{Zr}, \mathrm{Ba}$, 
and $\mathrm{Ce}$. The latter can be attributed to the presence of insoluble accessory minerals such as zircon, baryite and pyrochlore. The REE data using both methods are in good agreement.

Reproducibility of most elements ranges from $3-7 \%$ at the $1 \sigma$ level (Jackson, personal communication). Reproducibility for $\mathrm{Cs}$, Th, and $\mathrm{Tm}$ is about $9 \%$, that for $\mathrm{Nb}$ about $14 \%$, Ti about $24 \%$ and $\mathrm{Ba}$ about $40 \%$ (Bell, personal communication).

Table 6.1. Ratios of trace and rare earth elements $\left(\mathrm{Na}_{2} \mathrm{O}_{2}\right.$ Sinter/standard)

\begin{tabular}{|l|l|l|l|l|l|l|l||}
\hline & FFM100 & FFM101 & FFM102 & FFM103 & FFM104 & FFM105 & FFM106 \\
\hline $\mathrm{La}$ & 1.08 & 1.05 & 1.03 & 1.06 & 1.04 & 0.956 & 1.01 \\
\hline $\mathrm{Ce}$ & & 1.03 & 1.01 & 1.05 & 1.04 & 0.942 & 1.04 \\
\hline $\mathrm{Pr}$ & 1.09 & 1.06 & 1.02 & 1.03 & 1.03 & 0.970 & 1.01 \\
\hline $\mathrm{Nd}$ & 1.13 & 1.08 & 1.03 & 1.05 & 1.04 & 0.965 & 1.01 \\
\hline $\mathrm{Sm}$ & 1.08 & 1.10 & 1.05 & 1.03 & 1.02 & 1.06 & 0.993 \\
\hline $\mathrm{Eu}$ & 1.08 & 1.04 & 0.969 & 1.05 & 1.03 & 0.979 & 0.998 \\
\hline $\mathrm{Gd}$ & 0.847 & 1.20 & 1.16 & 0.993 & 1.12 & 1.11 & 1.13 \\
\hline $\mathrm{Tb}$ & & 1.31 & 1.18 & & 1.09 & 0.995 & 1.10 \\
\hline $\mathrm{Dy}$ & 0.979 & 1.03 & 1.03 & 1.02 & 1.08 & 0.914 & 0.958 \\
\hline $\mathrm{Ho}$ & 1.04 & 1.05 & 0.903 & 0.944 & 0.971 & 0.900 & 0.976 \\
\hline $\mathrm{Er}$ & 1.14 & 1.08 & 0.996 & 1.04 & 1.00 & 0.999 & 1.02 \\
\hline $\mathrm{Tm}$ & 0.885 & 0.976 & 0.996 & 1.01 & 1.02 & 0.850 & 1.11 \\
\hline $\mathrm{Yb}$ & 3.20 & 1.51 & 1.52 & 1.08 & 1.77 & 0.868 & 1.19 \\
\hline $\mathrm{Lu}$ & 1.94 & 1.27 & 1.10 & 1.09 & 1.09 & 0.885 & 0.885 \\
\hline $\mathrm{Y}$ & 1.02 & 1.06 & 1.14 & 1.05 & 1.05 & 0.926 & 0.910 \\
\hline
\end{tabular}

The XRF data for the major oxides, however, provided some problems because the totals did not sum to $100 \%$. In many cases the loss on ignition (LOI) added to the sums 
of the oxides were significantly less than $100 \%$. Some totals were as low as $96 \%$, but there are no obvious reasons for these discrepancies. The chemical data for all the analyzed elements are presented in Table 6.2. Major elements are by XRF, trace and REEs are by ICP-MS on sintered samples.

\subsection{Distribution of elements in the weathering profile}

\subsubsection{Rare earth elements}

Chondrite-normalized REE abundances for the analyzed samples are presented in Figure 6.1. Chondritic values were taken from Sun and McDonough (1989) and are included in Appendix C, Table C-4. REE abundances for average carbonatite (Wooley and Kempe, 1989) have been included in this study for comparison. The chondrite-normalized pattern for the average carbonatite is presented as AC in Fig.6.1.

The distribution patterns have the same trend for all the samples studied. All indicate enrichment in the REEs. The carbonatite samples (FFMl06 and 105) have lower REE abundances relative to average carbonatite. The mineralogy of sample FFM106 is similar to that of fresh carbonatites, and the normalized $\mathrm{La}$ and $\mathrm{Ce}$ values $(>1000$ times chondrite) support this interpretation. Sample FFM105, however, is strongly depleted in all of the REEs, and contains normalized values that are about $10 \%$ of those for sample FFM106.

Petrographic and geochemical analyses indicate higher contents of Fe-oxides and silica in FFM105 compared to FFM106 (Appendix C). The calcite crystals in sample FFM105do not show the anhedral and subhedral forms of those observed in sample FFM106, but are modified to more elliptical forms. Groundwater percolation and/or hydrothermal alteration 
Table 6.2. Major (wt \%), trace and rare earth elements (ppm) concentrations in the profile

\begin{tabular}{|c|c|c|c|c|c|c|c|}
\hline & FFM100 & FM101 & FFM102 & FFM103 & FFM104 & FM105 & FM106 \\
\hline $\mathrm{SiO} 2$ & 30.80 & 19.60 & 46.54 & 21.18 & 26.74 & 10.14 & 0.53 \\
\hline $\mathrm{TiO} 2$ & 0.74 & 2.73 & 0.90 & 3.97 & 1.07 & 0.01 & 0.01 \\
\hline $\mathrm{Al} 2 \mathrm{O} 3$ & 5.42 & 7.28 & 8.32 & 12.60 & 7.40 & 0.30 & 0.07 \\
\hline $\mathrm{Fe} 2 \mathrm{O} 3$ & 20.48 & 45.00 & 10.32 & 18.44 & 21.46 & 15.60 & 0.93 \\
\hline MnO & 0.31 & 0.72 & 0.60 & 0.81 & 0.64 & 0.26 & 0.38 \\
\hline $\mathrm{MgO}$ & 0.18 & 0.24 & 0.23 & 0.34 & 0.72 & 0.13 & 1.66 \\
\hline $\mathrm{CaO}$ & 13.04 & 7.18 & 13.03 & 14.08 & 14.30 & 38.48 & 50.86 \\
\hline $\mathrm{Na} 2 \mathrm{O}$ & 0.10 & 0.08 & 0.26 & 0.08 & 0.16 & 0.04 & 0.05 \\
\hline $\mathrm{K} 2 \mathrm{O}$ & 1.32 & 0.18 & 0.34 & 0.76 & 0.72 & 0.01 & 0.00 \\
\hline P2O5 & 11.45 & 4.55 & 6.88 & 7.75 & 7.61 & 0.09 & 0.61 \\
\hline $\mathrm{Zr}$ & 705 & 1540 & 591 & 901 & 572 & 150 & 24 \\
\hline $\mathrm{Nb}$ & 15300 & 5960 & 4440 & 8210 & 7130 & 140 & 360 \\
\hline $\mathrm{Ba}$ & 2080 & 2350 & 1250 & 1900 & 1830 & 282 & 947 \\
\hline $\mathrm{Sr}$ & 6982 & 3808 & 7215 & 22534 & 4926 & 435 & 2691 \\
\hline La & 5830 & 1900 & 1090 & 1590 & 3960 & 11 & 407 \\
\hline $\mathrm{Ce}$ & 11900 & 3170 & 2230 & 2990 & 7240 & 19 & 810 \\
\hline $\mathrm{Pr}$ & 1210 & 409 & 258 & 345 & 920 & 2 & 87 \\
\hline Nd & 4160 & 1410 & 909 & 1210 & 3220 & 9 & 300 \\
\hline $\mathrm{Sm}$ & 422 & 173 & 123 & 156 & 376 & 1 & 38 \\
\hline Eu & 94 & 41 & 30 & 40 & 95 & 1 & 10 \\
\hline Gd & 170 & 103 & 81 & 90 & 224 & 1 & 27 \\
\hline Dy & 75 & 49 & 44 & 54 & 109 & 1 & 13 \\
\hline Ho & 12 & 8 & 7 & 9 & 16 & 1 & 2 \\
\hline $\mathrm{Er}$ & 34 & 20 & 18 & 33 & 38 & 1 & 6 \\
\hline Tm & 4 & 2 & 2 & 3 & 5 & 1 & 1 \\
\hline Yb & 27 & 16 & 14 & 28 & 30 & 1 & 5 \\
\hline Lu & 3 & 2 & 2 & 3 & 4 & 1 & 1 \\
\hline Hf & 7 & 12 & 5 & 5 & 5 & 1 & 1 \\
\hline $\mathrm{Ta}$ & 26 & 20 & 36 & 22 & 3 & 1 & 1 \\
\hline Th & 14 & 202 & 124 & 128 & 108 & 1 & 6 \\
\hline Y & 292 & 214 & 216 & 246 & 425 & 7 & 59 \\
\hline
\end{tabular}




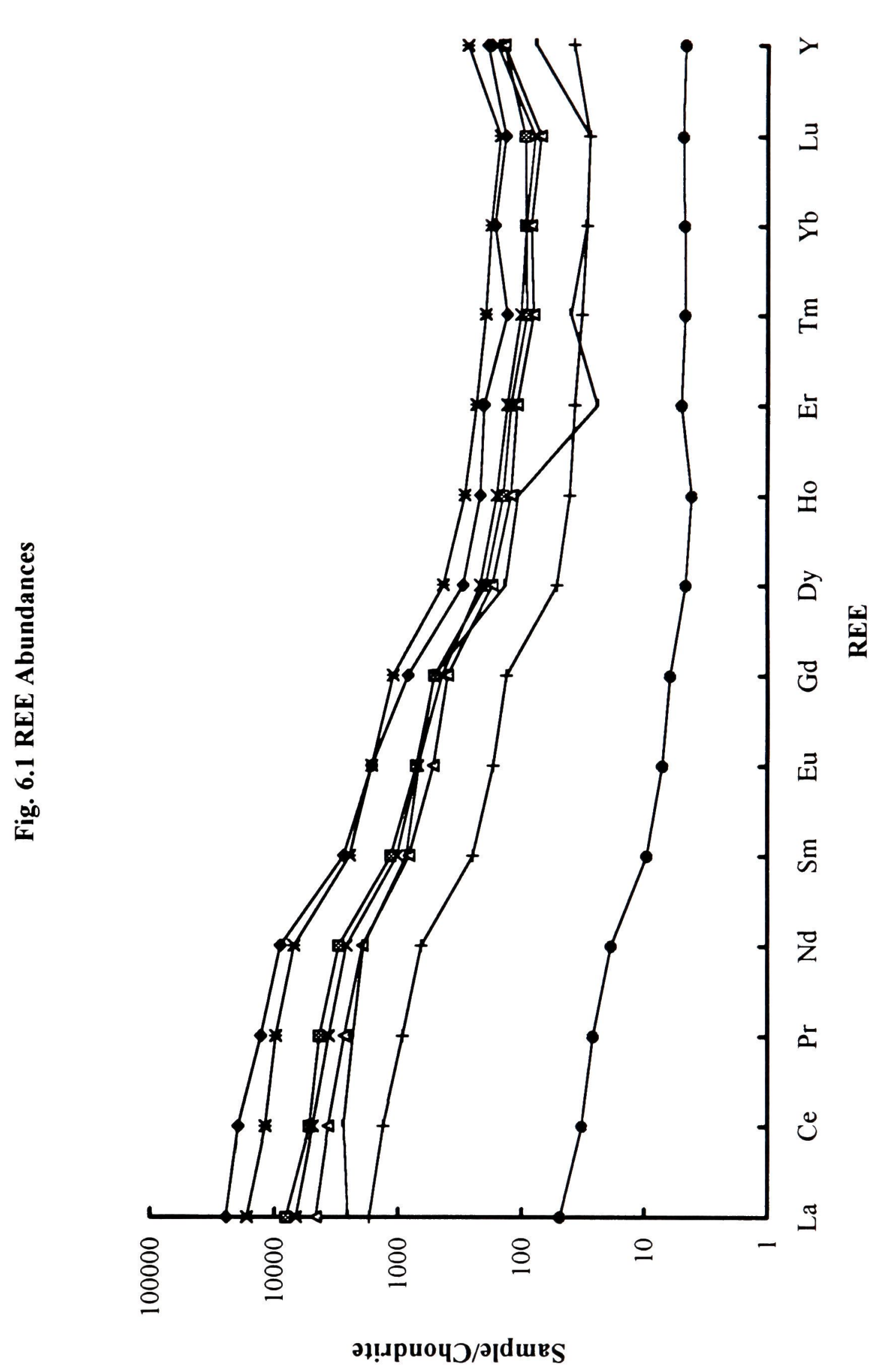

63

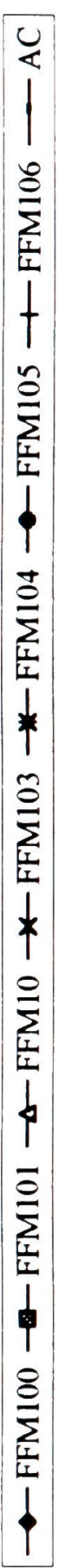


are possible explanations in sample FFM105 for the removal of some Ca and REEs and introduction of $\mathrm{Fe}$ and $\mathrm{Si}$, from the country rocks. The $\mathrm{Fe}$ and $\mathrm{Si}$ have recrystallized as Fe-oxides and secondary quartz in fractures within the carbonatite.

Patterns from the weathered materials above Panda Hill carbonatite are all REE-enriched relative to the average carbonatite. However, they do not show a systematic distribution between zones. The saprolite zone indicates highest REE abundances at the base and the lowest at the top (FFM104>103>102). An increase in REE contents is observed in materials just above the upper saprolite zone. The highest REE abundances in the whole profile are found in sample FFM100. Enrichment is probably due to the concentration in this zone of elements leached from the upper layers $(<2.5 \mathrm{~m})$.

Figure 6.2 presents the distribution of total REE with respect to the sampling depth.

\subsubsection{Major and trace elements}

The variation of REE trends in a weathering profile, such as the one observed at Panda Hill, is also related to the variations in the abundances of other major and trace elements, especially those likely to form complexes with REEs. The major and trace elements selected in this section are those which participate in forming the REE-bearing minerals found in the studied samples, i.e $\mathrm{Ca}, \mathrm{P}, \mathrm{Al}, \mathrm{Fe}, \mathrm{Ba}$ and $\mathrm{Sr}$. The abundances of these elements ( $w t \%$ oxide) in the studied profile are plotted, for correlation purposes, in Fig.6.3a-c.

The highest $\mathrm{P}_{2} \mathrm{O}_{5}$ abundances were obtained from sample FMl00 (Fig.6.3a), which was collected $2.5 \mathrm{~m}$ from the surface. The $\mathrm{P}_{2} \mathrm{O}_{5}$ in this sample is contained in apatites 
Fig.6.2. Distribution of REE in the studied profile

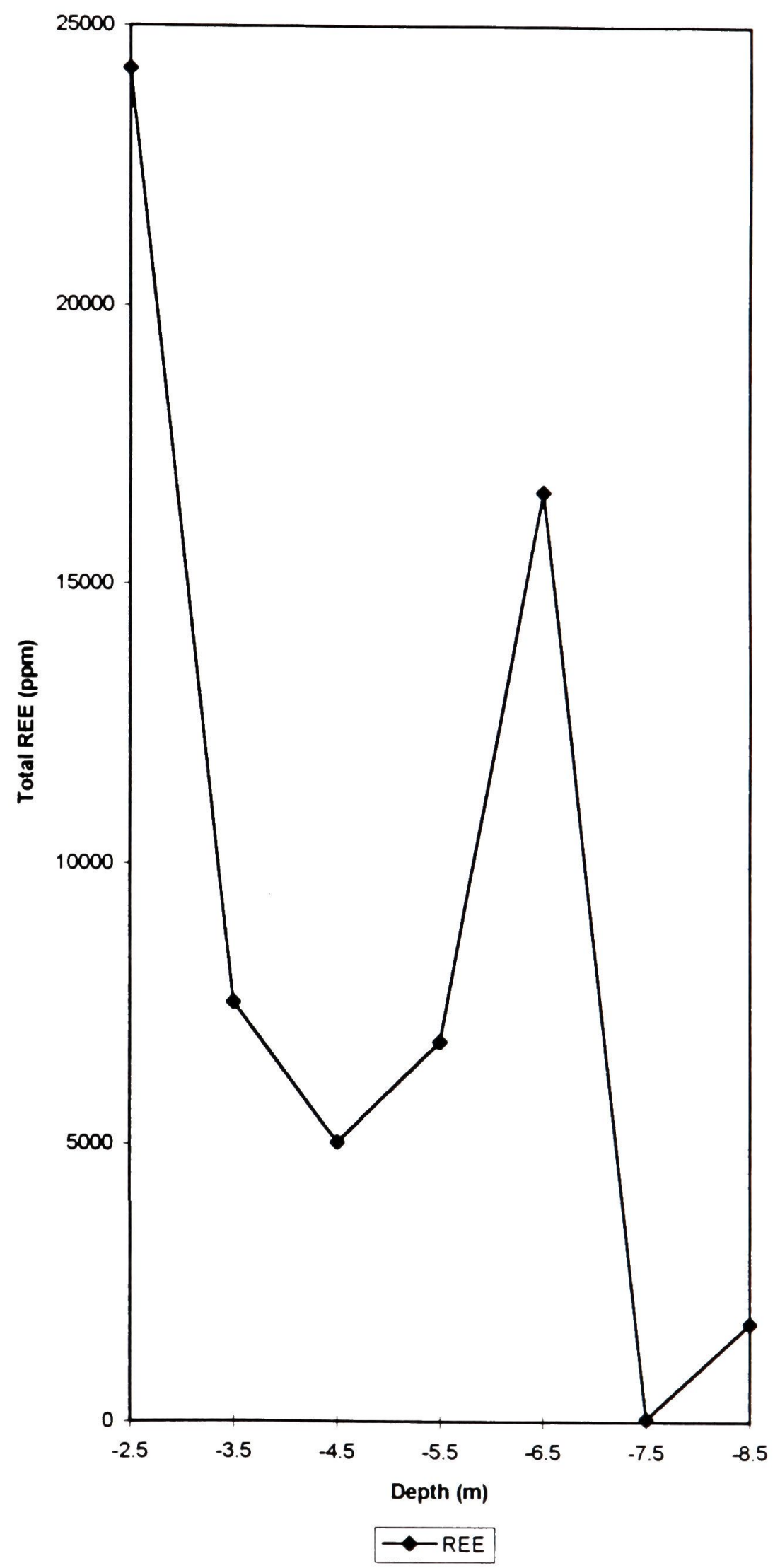


transported from upper slopes. The presence of fresh apatites in sample FFM100 is also indicated by the distribution pattern for $\mathrm{CaO}$ (Fig.6.3a). The $\mathrm{CaO}$ content in this sample is comparable to those in samples FFM102 to FFM104, the other zone of phosphate enrichment. $\mathrm{CaO}$ on the other hand, generally decreases from over $50 \%$ in the carbonatite sample FFM106 to less than $15 \%$ in the weathered materials. This supports the argument that most of the $\mathrm{Ca}$ from the dissolving calcite is flushed out of the system.

The behaviour of $\mathrm{Sr}$ and $\mathrm{Ba}$ in the profile was examined because these elements are involved in the formation of secondary phosphates. Fig.6.3b indicates that the highest $\mathrm{Sr}$ value occur in sample FFM103 (about 23000ppm). However, the total contents of $\mathrm{Sr}$ in the slightly weathered carbonatite (sample FFM106) is very low and still lower in sample FFM105. This shows that the elements involved in the formation of secondary phosphates are not only released from the primary carbonatite minerals, but are also leached from the upper zones of the profile. Barium is also high in the saprolite, about $1700 \mathrm{ppm}$ on average (Fig.6.3b). The high contents of $\mathrm{Ba}$ and $\mathrm{Sr}$ in saprolite indicate that these elements are involved in the formation of secondary minerals.

Hydrated oxides of $\mathrm{Fe}$ and $\mathrm{Al}$ are common in weathering profiles of tropical regions. The profile at Panda Hill indicates high $\mathrm{Al}_{2} \mathrm{O}_{3}$ in the saprolite (sample FFM103) and high $\mathrm{Fe}_{2} \mathrm{O}_{3}$ in the loose materials above the saprolite (Fig.6.3c). Al- and Fe-bearing primary minerals are rare in the Panda Hill carbonatite. The small amounts of $\mathrm{Al}$ and $\mathrm{Fe}$ in samples FFM106 and FFM105 may be attributed to alteration processes. The high content of $\mathrm{Al}$ in the saprolite is probably due to the concentration, in this zone, of $\mathrm{Al}$ leached from the country rocks and transported in the groundwater. In the saprolite, Al was 
67

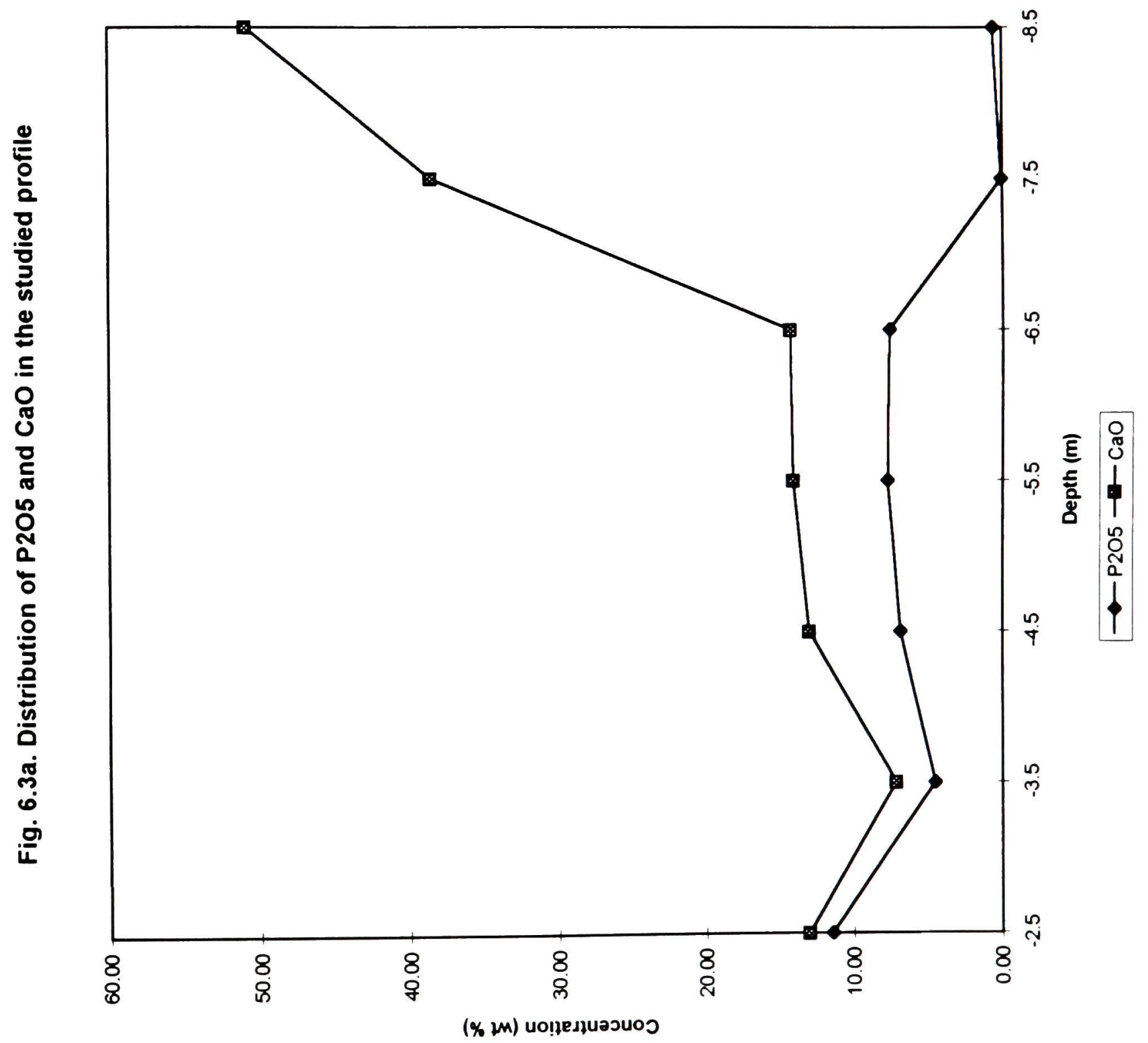




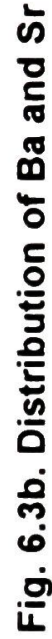

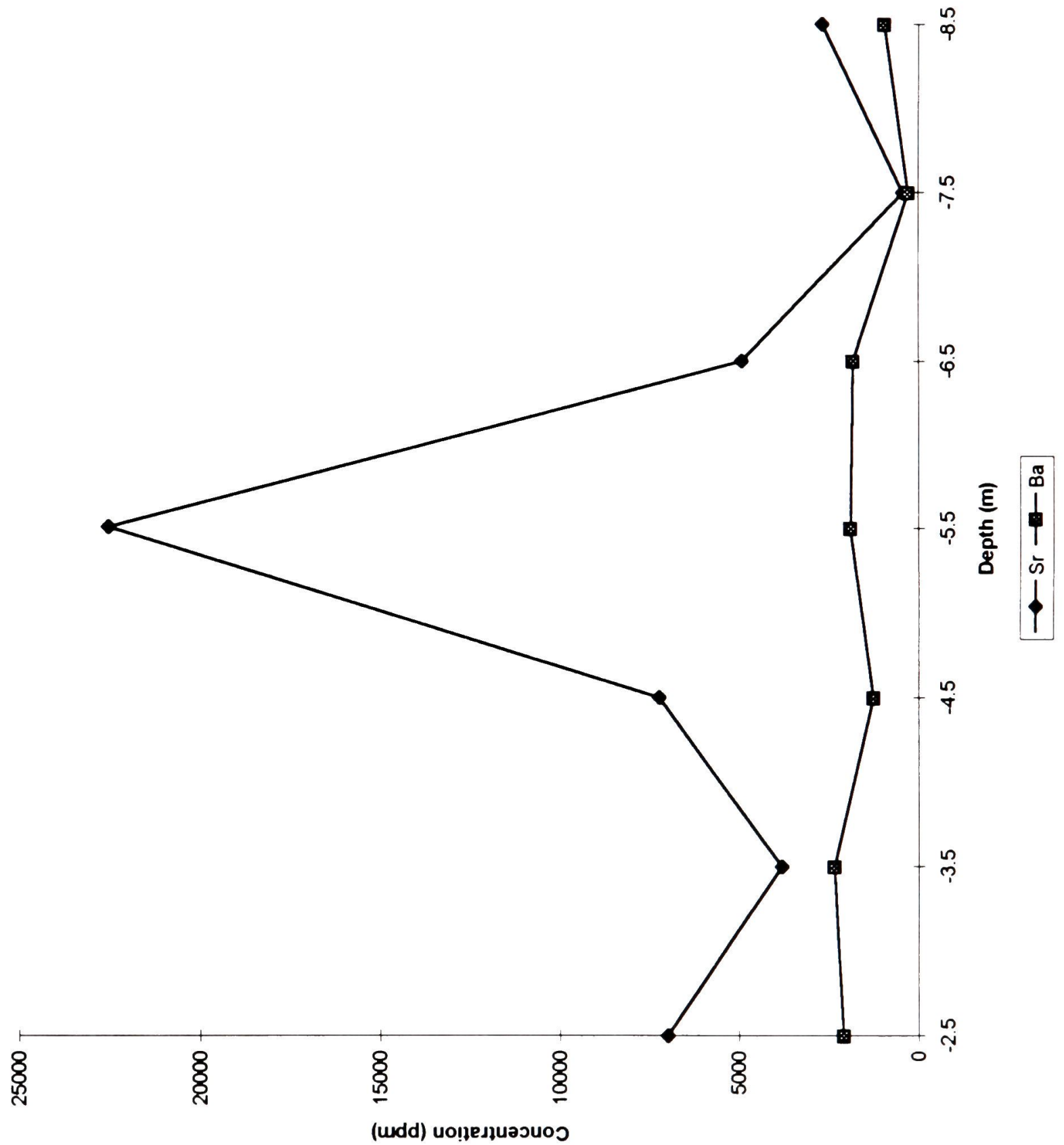


Fig. 6.3c. Distribution of $\mathrm{Al} 2 \mathrm{O} 3$ and $\mathrm{Fe} 2 \mathrm{O} 3$ in the studied profile

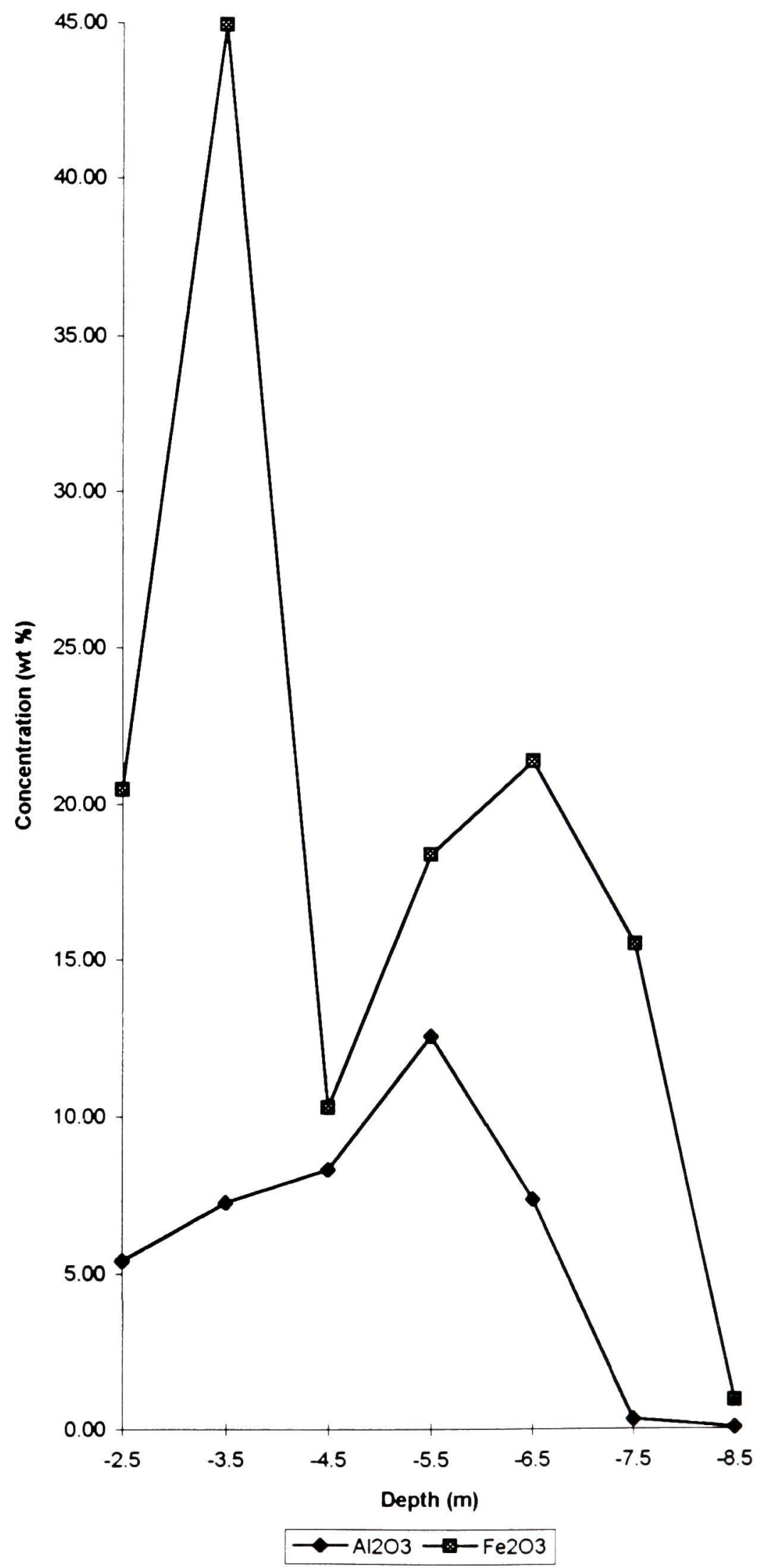


redeposited as oxide, clay mineral (kaolinite) and participated in the formation of secondary phosphates, in this case goyazite. High contents of $\mathrm{Fe}_{2} \mathrm{O}_{3}$ in sample FFMlOl may be attributed to the high amount of magnetite in the materials. The relationship between the distribution of REEs and other elements in the profile was examined further by the use of a mantle-normalized spider diagram (Fig.6.4). The plot was prepared from ratios obtained from absolute abundances normalized to primitive mantle values taken from Sun and McDonough (1989) [Appendix C, Table C-4]. There is a general tendency for all the samples to show the same patterns, i.e. all of the samples are either enriched or depleted in the same elements. All of the samples, other than sample FFM105, indicate troughs at $\mathrm{Zr}, \mathrm{Hf}, \mathrm{K}$ and $\mathrm{Rb}$, and peaks at $\mathrm{U}, \mathrm{La}, \mathrm{Ce}$ and $\mathrm{Nd}$. The distribution patterns indicate low abundances in most elements for sample FFM105 except for molybdenum, which is high in this sample relative to all other samples studied.

The variations in the abundances of some least-mobile elements was studied in order understand the losses or gains of material in the profile. High concentrations of an immobile element in a zone can be attributed to removal of other elements, leading to the accumulation of the immobile element. $\mathrm{Zr}$, $\mathrm{Hf}$ and $\mathrm{Th}$ have been used for this interpretation. Depletions and enrichments of $\mathrm{Zr}$, $\mathrm{Hf}$ and $\mathrm{Th}$ in the profile follow the same patterns (Fig.6.5). Calculations of the concentration changes in the profile for the three elements relative to sample FFM106 indicate that the elements have been concentrated in the saprolite. 


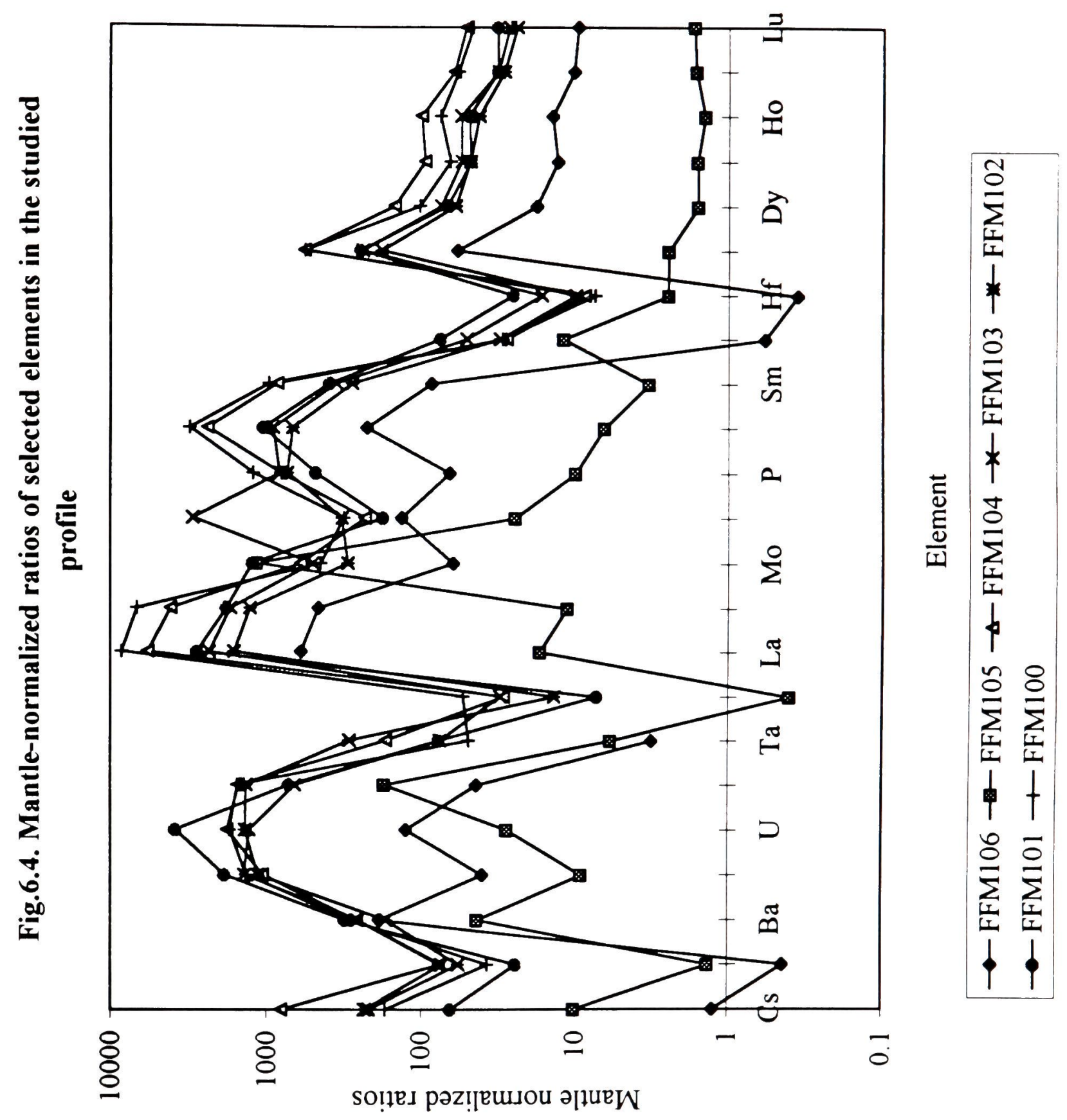


Fig. 6.5. Distribution of $\mathrm{Zr}, \mathrm{Hf}$ and $\mathrm{Th}$ in the profile

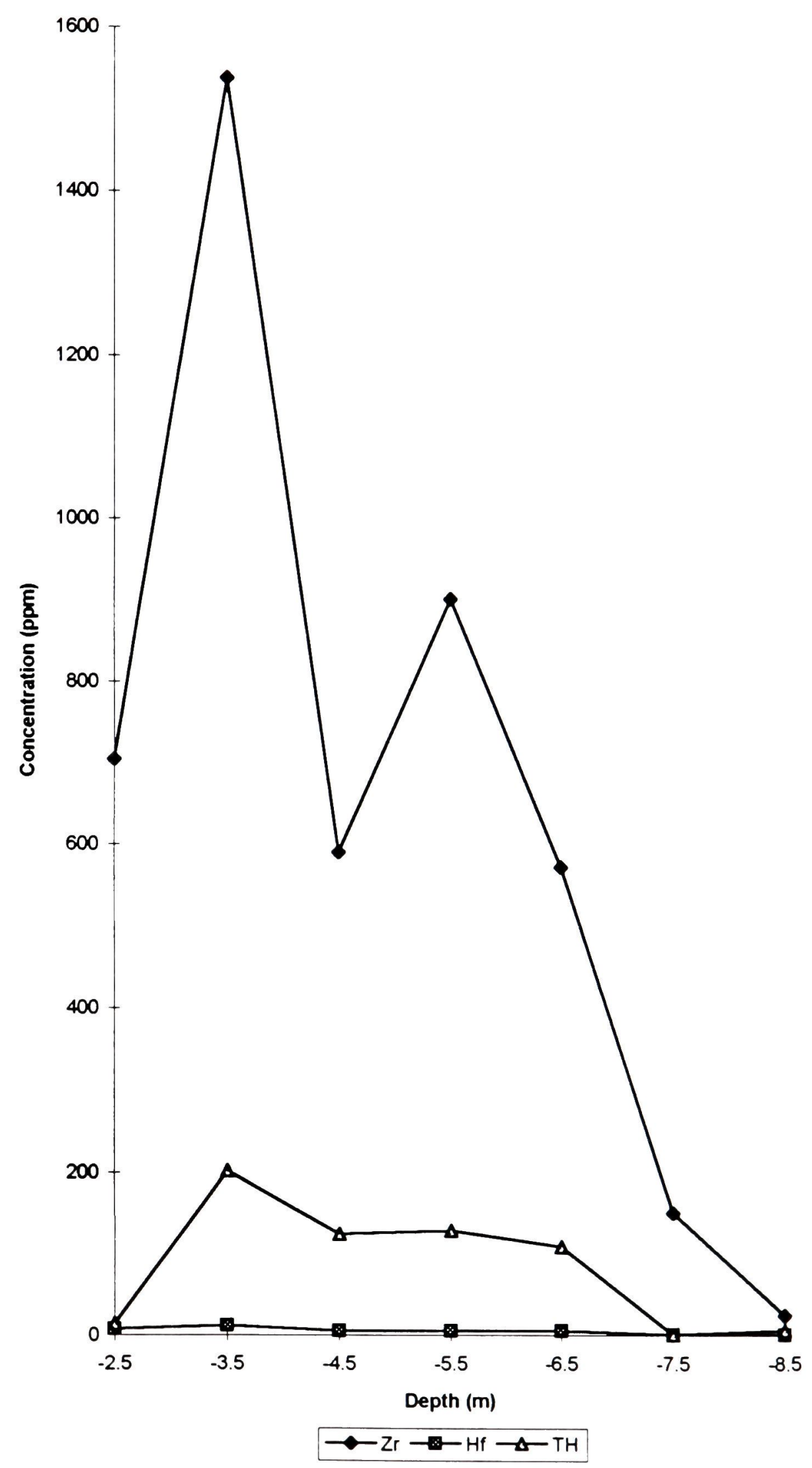


Table 6.3 shows the changes in concentrations for $\mathrm{Zr}$, Hf and Th. The first series of values for $\mathrm{Zr}$, Hf and $\mathrm{Th}$ in the Table were obtained from ratios of the concentrations in samples FFM100 to FFM105 relative to sample FFM106. The second series values were obtained from calculations based on the densities of the samples, using the method by Nesbitt (1979) and Braun et al. (1993).

The densities of the samples are FFM100 $=2.70$, FFM101 $=2.79$, FFM102 $=2.75 \mathrm{~g} / \mathrm{cc}$, FFM103 $=2.95$, FFM104=2.82, FFM105 $=3.36$, and FFM106=3.09g/cc.

Table 6.3: $\mathrm{Zr}$, Hf and Th concentrations relative to FFM106 in the profile above Panda Hill carbonatite

\begin{tabular}{||l|l|l|l|l|l|l||}
\hline \hline Sample & 100 & 101 & 102 & 103 & 104 & 105 \\
\hline $\mathrm{Zr}$ & 24.39 & 51.381 & 19.699 & 30.012 & 19.062 & 4.998 \\
\hline Hf & 19.209 & 33.605 & 14.774 & 30.975 & 14.234 & 1.997 \\
\hline Th & 22.032 & 32.839 & 20.163 & 20.550 & 17.622 & 0.150 \\
\hline & & & & & & \\
\hline $\mathrm{Zr}$ & 19.221 & 45.392 & 16.531 & 27.653 & 16.396 & 4.435 \\
\hline Hf & 15.786 & 29.343 & 12.149 & 24.027 & 9.994 & 1.172 \\
\hline Th & 18.251 & 28.651 & 16.944 & 18.619 & 14.952 & -0.836 \\
\hline
\end{tabular}

The calculated ratios support the coincident depletion and enrichment of $\mathrm{Zr}$, Hf and Th. The depletion of mobile elements from the profile increases from the carbonatite to $5.5 \mathrm{~m}$ (sample FFM103). Concentration decrease in the $4.5 \mathrm{~m}$ (sample FFM102) zone due to dilution by the high silica contents (Table 6.2), suggestive of country rock mixed with the outermost portion of the carbonatite body. High contents in the overlying soil are probably due to leaching from upper horizons. 


\section{CHAPTER 7 - SUMMARY AND CONCLUSIONS}

The variations of major, trace and rare earth element concentrations in the weathering profile above Panda Hill carbonatite in the area studied show great inconsistency. The irregularities in the distribution of phosphate and REEs in the different zones of the profile make interpretation difficult. The high concentrations of apatite and REEs in the soil above the saprolite have not been interpreted in detail, because this zone consists predominantly of material transported from higher slopes.

The lowest abundances for most elements occur in sample FFM 105, and no obvious explanation exists for these differences. Relative to FFM 106, the abundances of Fe, Al and $\mathrm{Si}$ are higher, while $\mathrm{Ca}$ and the REEs are lower.

The saprolite zone is the main zone of enrichment for phosphates and the REEs. The concentrations of phosphate throughout the saprolite zone, i.e. sample FFM104 to sample FFM102, are comparable. Almost all the $\mathrm{P}_{2} \mathrm{O}_{5}$ is present as apatite at the base of the saprolite. Secondary $\mathrm{Ba}, \mathrm{Sr}, \mathrm{Al}$, and REE phosphates also control the distribution of $\mathrm{P}_{2} \mathrm{O}_{5}$ in the upper saprolite. The secondary phosphate minerals can also release phosphate as weathering intensity increases. This means that phosphate can be remobilized and redistributed, depending on the degree of weathering. The contributions from different phosphate minerals to the total $\mathrm{P}_{2} \mathrm{O}_{5}$ concentrations in the weathered samples was difficult to evaluate because the grains are too small to be separated out for detailed study.

The REEs are also enriched in samples from the saprolite, relative to the carbonatite. However, the nature of the enrichment process and the REE-bearing minerals that were involved in providing the REEs are not completely understood. 
The concentrations of $\mathrm{Zr}$, Hf and $\mathrm{Th}$ indicate that these elements behave in the same way in the weathering profile above Panda Hill. These elements are all enriched or depleted in the same samples. $\mathrm{Zr}, \mathrm{Hf}$ and $\mathrm{Th}$ are also concentrated in the saprolite. This indicates that removal of elements from the saprolite zone has allowed the concentration of the less mobile elements.

The conclusions concerning the behavior of phosphate and REEs in the weathering profile above Panda Hill carbonatite are:

1) Phosphate and REEs are enriched in the saprolite zone.

2) Phosphate is partially mobilized during alteration of apatite and redistributed in the saprolite zone. The released phosphate participates in the formation of secondary phosphates, i.e monazite and rhabdophane. Much of the phosphate remains in the original apatite structure. Isomorphous substitution of $\mathrm{Ba}, \mathrm{Al}, \mathrm{Sr}$ and $\mathrm{REEs}$ in the apatite structure immobilizes phosphate in the form of secondary minerals of the crandallite group and aluminous phosphate-sulphates. The crandallite group mineral found at Panda Hill is goyazite and the aluminous phosphate-sulphate is svanbergite.

3) REEs are mobilized during alteration of the carbonatite. The low abundances of REEs in sample FFM 105 that lies immediately above carbonatite sample FFM 106 suggest that migration of the REEs has taken place.

4) REEs are also probably leached from upper zones of the weathering profile and from the country rocks. In the saprolite zone (the zone of groundwater circulation), the REEs are either reprecipitated as secondary REE minerals (monazite and rhabdophane) or incorporated into the secondary phosphate minerals (goyazite and svanbergite). 
5) $\mathrm{Zr}$, Hf and Th are concentrated in the saprolite and the zone overlying saprolite. Of these elements, $\mathrm{Zr}$ appears to be the least mobile. The concentrations of $\mathrm{Zr}, \mathrm{Hf}$ and $\mathrm{Th}$ imply removal of other elements from these two zones and support the argument that REEs, $\mathrm{Al}, \mathrm{Ba}$ and $\mathrm{Sr}$ can be remobilized and be redistributed to other parts of the profile or completely removed.

6) The findings from petrographic and geochemical studies are similar. Microscopy provided evidence for the removal of calcite and the accumulation of apatite and the formation of iron oxide during the weathering process. XRF and ICP-MS analyses showed that $\mathrm{Ca}$ is removed and that phosphate, trace and rare earth elements are enriched. Scanning electron microscopy and energy-dispersive $\mathrm{X}$-ray analysis indicated that secondary phosphate minerals were formed during weathering, and enabled identification of the zones of enrichment. 


\section{REFERENCES}

Altschuler, Z.S.; 1973. The weathering of phosphate deposits: geochemical and environmental aspects. In: E.J.Griffin, A. Beeton, J.M. Spencer and D.T. Mitchell (Eds). Environmental Phosphorus Handbook, pp 33-96.

Andersen, T.; 1984. Secondary processes in carbonatites: petrology of "rødberg" hematite-calcite-dolomite carbonatite, in the Fen central complex, Telemark (South Norway). Lithos 17: 227-245.

Andersen, T.; 1986. Compositional variation of some rare earth minerals from the Fen complex (Telemark, SE Norway): Implications for the mobility of rare earths in a carbonatite system. Miner. Magaz. 50: 503-509.

Barker, D.S.; 1989. Field relations of carbonatites. In K. Bell (Ed). Carbonatites: Genesis and Evolution pp 38- 69

Basu, N.K. and A. Mayila; 1986. Petrographic and chemical characteristics of the Panda Hill carbonatite complex, Tanzania. J. African Earth Sci. 5: 589-598

Batiano, A; S.H. Chien and A.U. Mokwunye; 1987. Chemical characteristics and agronomic values of some phosphate rocks in West Africa. In: J.M.

Menyonga, T. Bezuneh and A. Youdeowei (Eds). Food grain production in semi- arid Africa.

Bayliss, P and A.A. Levinson; 1988. A system of nomenclature of rare earth mineral species: Revision and extension. Am. Min. 73: 422-423.

Bell, K. and J. Blenkinsop, 1987. Nd and Sr isotopic compositions of the East African carbonatites: Implications for mantle heterogeneity. Geol. 15: 99- 102.

Braun, J.J; M. Pagel; J.P. Muller; P. Bilong; A. Michard and B. Gullet; 1990. Cerium anomalies in lateritic profiles. Geochim. Cosmochim. Acta 54: 781-795.

Braun, J.J; M. Pagel; A. Herbillon and C. Rosin; 1993. Mobilization and redistribution of REEs and thorium in a syenitic lateritic profile: A mass balance study. Geochim. Cosmochim. Acta 57: 4419-4434.

British Sulphur Corporation. 1971. World Survey of Phosphate Deposits. 3rd Edition. London, England.

Chesworth, W.; J.M.R.Semoka; P. van Straaten; P.N.S. Mnkeni; J.A.M. Kamasho and E.P. Mchihiyo; 1988. Tanzania- Canada Agrogeology Project. Report on completion of the first phase. Unpub. rep. Univ. of Guelph, Ont. Canada. 
Chesworth, W., 1992. Weathering systems. In: Martini, I.P. and W. Chesworth (Eds).Weathering, soils and paleosols. Devel. in Earth Surface Processes 2 1938.

Clark, A.M.; 1984. Mineralogy of the rare earth elements. In: P. Henderson (Ed). Rare Earth Element Geochemistry. Devel. in Geochem. 2: 33-61.

Cullers, R.L. and J.L. Graf; 1984. Rare earth elements in igneous rocks of the continental crust: Predominantly basic and ultrabasic rocks. In: P. Henderson (Ed). Rare Earth Element Geochemistry. Devel. in Geochem. 2: 237-274.

Dawson, J.B., 1989. Sodium carbonatite extrusions from Oldoinyo Lengai, Tanzania: Implications for carbonatite complex genesis. In: K. Bell (Ed). Carbonatites: Genesis and evolution, p 255.

Devies, H. R. J, 1973. Tropical Africa on Atlas for Rural Development. University of Wales Press.

Duddy, J.R.; 1980. Redistribution and fractionation of rare earths and other elements in a weathering profile. Chem. Geol. 30: 363-381.

Eby, G.N.; 1975. Abundance and distribution of rare earth elements and Yttrium in the rocks and minerals pf the Oka carbonatite complex, Quebec. Geochim. Cosmochim. Acta 39: 597-620.

ESAMRDC, 1993. Small scale partial acidulation of phosphate rock. Laboratory studies conducted on Panda Hill phosphate ore. Unpubl. rep. Eastern and Southern African Mineral Resources Development Centre, Dar-eSsalaam, Tanzania.

Fawley, A.P and T.C. James; 1955. A pyrochlore (columbium) carbonatite, southern Tanganyika. Econ. Geol. 50: 571- 585.

Fick, L.J. and C. van der Heyde; 1959. Additional data on the geology of the Mbeya Carbonatite. Econ. Geol. 54: 842-872.

Flicoteaux, R. and J. Lucas; 1984. Weathering of phosphate minerals. In: J.O. Nriagu and P.B. Moore (Eds). Phosphate Minerals, pp 292-317.

Gittins, J., 1989. The origin and evolution of carbonatite magma. In: K. Bell (Ed). Carbonatites: Genesis and evolution, pp 580-598. 
Haggerty, S.E; 1989. Mantle metasomes and the kinship of carbonatites and kimberlites. In: K. Bell (Ed). Carbonatites: Genesis and evolution pp 554.

Hamilton, D.L.; P. Bedson and J. Esson; 1989. The behaviour of trace elements in the evolution of carbonatites. In: K.Bell (Ed). Carbonatites: Genesis and evolution p 405.

Hammond, L.L.; S.H. Chien and A.U. Mokwunye, 1986. Agronomic value of unacidulated and partially acidulated phosphate rock indigineous to the tropics. In: N.C. Brady,(Ed). Advances in agronomy 40 89-137.

Hammond, L.L; S.H. Chien; A.H. Roy and A.U. Mokwunye; 1989. Solubility and agronomic effectiveness of partially acidulated phosphate rocks as influenced by their iron and aluminium oxide content. Fert. Res. 19: 93-98

Harris, J. 1961. Summary of the geology of Tanzania: Economic Geology. Tanganyika Geol. Surv. Mem.1 (4). of Tanzania.

Henderson, P.; 1984. General geochemical properties and abundances of the rare earth elements. In P.Henderson(Ed). Rare Earth Element Geochemistry. Dev. in geochem. 2: 1-32.

Hogarth, D.D.; 1989. Pyrochlore, apatite and amphiboles: distinctive minerals in carbonatites. In: K. Bell (Ed). Carbonatites: Genesis and evolution, pp 105140 .

Humphris, S.E.; 1984. the mobility of the rare earth elements in the crust. In: P. Henderson (Ed). Rare Earth Element Geochemistry. Devel. in Geochem. 2: 317-373.

James, T.C.; 1954. Preliminary report on geological investigations at Panda Hill, Mbeya District. Report, Geol. Surv. Tanganyika.

Kapustin, Y.L.; 1980. Mineralogy of carbonatites. Translated from Russian, "Mineralogiya karbonatitov".

Khasawneh, F.E., and E.C. Doll, 1978. The use of phosphate rock for direct application. In: N.C. Brady (Ed). Advances in agronomy 30 159-204.

Le Bas, M.J.; 1989. Diversification of carbonatites. In: K. Bell (Ed). Carbonatites: Genesis and Evolution

Loubet, M.; M. bernat; M. Tavoy and C.J. Allegre.; 1972. Rare earth contents in carbonatites. Earth Plan. Sci. Lett. 14: 226-232. 
Mariano, A.N.; 1989a. Nature of economic mineralization in carbonatites and associated rocks. In: K. Bell (Ed). Carbonatites: Genesis and evolution, PP 149-172.

Mariano, A.N.; 1989b. Economic geology of rare earth minerals. In: B.R. Lipin and G.A. McKay (Eds). Geochemistry and mineralogy of rare earth elements. Rev.in Min. 21: 309-337.

McClellan, G.H and A.J.G. Notholt; 1986. Phosphate deposits of tropical sub-Saharan Africa. In: A.U. Mokwunye and P.L.G.Vlek; Management of nitrogen and phosphorus fertilizers in sub-Saharan Africa. Proceedings of a symposium held in Lome, Togo; March 25-28, 1985.

Mchihiyo, E.P., 1990. Geochemical and mineralogical aspects associated with weathering of apatite from Panda Hill carbonatite, SW Tanzania. M.Sc. Thesis Univ. of Guelph.

McKie, D.; 1962. Goyazite and florencite from two African carbonatites. Miner. Magaz. 33: 281-297.

Moller, P.; G. Morteam and F. Schley; 1980. Discussion of rare earth element distribution patterns of carbonatites and alkaline rocks. Lithos 13: 171-179.

Moore, P.B.; 1984. Crystallochemical Aspects of the phosphate minerals. In: J.O. Nriagu and P.B. Moore (Eds). Phosphate Minerals, pp 155-170.

Morisset, N., 1992. Stable isotope and radioisotope geochemistry of the Panda Hill carbonatite, Tanzania. M.Sc. Thesis, Carleton U.

Nash, W.P.; 1984. Phosphate minerals in terrestrial igneous and metamorphic rocks. In: J.O. Nriagu and P.B. Moore (Eds). Phosphate Minerals, pp 215-241.

Nesbitt, H.W.; 1979. Mobility and fractionation of rare earth elements during weathering of a granodiorite. Nature 279: 206-210.

Ngwenya, B.T.; 1992. Hydrothermal rare elements in carbonatite of the Tundulu complex, Malawi: Processes at fluid/rock interface. Geochim. Cosmochim. Acta 58 (9): 2061-2072.

Nriagu, J.O.; 1984. Phosphate minerals: Their properties and general modes of occurrence. In: J.O. Nriagu and P.B. Moore (Eds). Phosphate Minerals, pp 1-136. 
Reedman, J.H.; 1984. Resources of phosphate, niobium, iron and other elements in residual soils over the Sukulu carbonatite complex, SE Uganda. Econ. Geol. Bull. Soc. Econ. Geologists 79(4): 716-724.

RUDIS, 1980. Pre-feasibility study: Fertilizer raw materials. Report, Lubljana, Yugoslavia.

Sholkovitz, E.R.; 1992. Chemical evolution of rare earth elements: Fractionation between colloidal and solution phases of filtered river water. Earth Planet. Sc. Lett 114(1): 77- 84.

Spötl, C.; 1990. Authigenic aluminium phosphate-sulphates in sandstones of the Mitterberg Formation, Northern Calcareous Alps, Austria. Sedimentology 37: 837-845.

Snelling, N.J.; 1965. Age determination on three African carbonatites. Nature 205: 491

Straaten, van P., J.M.R. Semoka, J.A.M. Kamasho, E.P. Mchihiyo, P.N.S. Mnkeni and W. Chesworth, 1992. Report on the results of the Tanzania Canada Agrogeology project, second phase. Unpub. rep. Univ. of Guelph, Ont. Canada.

Straaten, van P., 1989. Nature and structural relationships of carbonatites from southwest and west Tanzania. In: K. Bell (Ed). Carbonatites: Genesis and evolution, pp 177- 195.

Sun, S. and W.F. McDonough; 1989. Chemical and isotopic systems in the oceanic basalts: implications for mantle composition and process. In: A.D. Saunders and M.J. Norry (Eds). Magmatism in the ocean basins. Geol. Soc. Spec. Pub. 42: 318

UNDTCD, 1991. Opportunities for mineral resource development, Tanzania. Unpublished paper prepared by the United Nations Department of Technical Cooperation for Development and the Ministry of Water, Energy and Minerals; for the Government of Tanzania.

van Chi-Bonnardel, R., 1973. The Atlas of Africa. The Free Press, N.Y.

Vieillard, P. and Tardy, Y.; 1984. Thermochemical properties of phosphate minerals. In: J.O. Nriagu \& P.B. Moore (Eds). Phosphate minerals: pp 171-197. 
Vlasov, K.A. (Ed); 1966. Geochemistry of rare elements: Geochemistry and mineralogy of rare elements and genetic types of their deposits, I: 1-13; 128$155 ; 188-277$.

Vlasov, K.A. (Ed); 1966. Mineralogy of rare elements: Geochemistry and mineralogy of rare elements and genetic types of their deposits, II: 220-328.

Wambeke, L. van; 1960. Geochemical prospecting and appraisal of niobium-bearing carbonatites by X-ray methods. Econ. Geol. 55(4): 732-758.

Wooley, A.R. and D.R.C. Kempe.; 1989. Carbonatites: Nomenclature, average chemical composition and distribution of elements. In: K. Bell (Ed). Carbonatites: Genesis and evolution.

Wyllie, P.J; 1989. Origin of carbonatites: Evidence from phase equilibrium studies. In: K. Bell (Ed). Carbonatites: Genesis and Evolution. 


\section{APPENDICES}

APPENDIX A: Description of samples from Panda Hill carbonatite and associated rocks

Table A-1: Samples from pits 16, 30, 51 and drill hole 6

\begin{tabular}{|c|c|c|c|c|}
\hline $\begin{array}{l}\text { Location } \\
\text { on slope }\end{array}$ & Ref. & & Descripti & Rock type \\
\hline \multirow[t]{7}{*}{$\begin{array}{l}\text { Lower } \\
\text { (DH6) }\end{array}$} & FFM100 & 2.5 & $\begin{array}{l}\text { Reddish-brown soil } \\
+ \text { rock material }\end{array}$ & Mixed \\
\hline & FFM101 & 3.5 & $\begin{array}{l}\text { yellowish-brown } \\
\text { material + frags. }\end{array}$ & $\begin{array}{l}\text { weathered } \\
\text { carbonatite }\end{array}$ \\
\hline & FFM102 & 4.5 & $\begin{array}{l}\text { yellowish rock } \\
\text { material+frags }\end{array}$ & $\begin{array}{l}\text { weathered } \\
\text { carbonatite }\end{array}$ \\
\hline & FFM103 & 5.5 & $\begin{array}{l}\text { yellowish, sandy } \\
\text { rock material }\end{array}$ & $\begin{array}{l}\text { weathered } \\
\text { carbonatite }\end{array}$ \\
\hline & FFM104 & 6.5 & $\begin{array}{l}\text { yellowish, fine } \\
\text { soilt soft aggr. }\end{array}$ & $\begin{array}{l}\text { weathered } \\
\text { carbonatite }\end{array}$ \\
\hline & FFM105 & 7.5 & $\begin{array}{l}\text { coarse grained } \\
\text { white-gray, rock } \\
\text { brown fill in fr. }\end{array}$ & carbonatite \\
\hline & FFM106 & 8.5 & $\begin{array}{l}\text { white-gray coarse } \\
\text { crystalline rock }\end{array}$ & carbonatit \\
\hline
\end{tabular}

frags: fragments, aggr:aggregates, fr:fractures.

Lower FFM31 $0.25 \quad$ Dark brown soil

(Pit 51)

FFM31-34 0.25-1 reddish-brown

soiltrrags weathered carb

FFM35-40 1-3.5 reddish-brown

reddish-rock

frags

weathered carb

FFM41-43 3.5-5.4 dark-brown

materialt

reddish soil weathered carb 


\begin{tabular}{|c|c|c|c|c|}
\hline \multirow{4}{*}{$\begin{array}{l}\text { Middle } \\
\text { (Pit30) }\end{array}$} & FFM22 & 0.25 & \multicolumn{2}{|l|}{ dark brown soil } \\
\hline & FFM23-26 & $0.25-1.25$ & \multirow{2}{*}{$\begin{array}{c}\text { fine, yellowish } \\
\text { material } \\
\text { medium, reddish }\end{array}$} & \multirow{2}{*}{$\begin{array}{l}\text { weathered } \\
\text { fenite } \\
\text { weathered } \\
\text { fenite }\end{array}$} \\
\hline & FFM27-29 & $1.25-2.25$ & & \\
\hline & FFM30 & $2.25-2.8$ & $\begin{array}{l}\text { +rock frags } \\
\text { coarse, rock } \\
\text { gneiss texture }\end{array}$ & $\begin{array}{l}\text { Ienite } \\
\text { weathered } \\
\text { fenite }\end{array}$ \\
\hline \multirow[t]{4}{*}{$\begin{array}{l}\text { Upper } \\
\text { (Pit 16) }\end{array}$} & FFM13 & 0.25 & \multirow{3}{*}{$\begin{array}{l}\text { dark brown } \\
\text { nodular soil } \\
\text { dark-brown } \\
\text { material } \\
\text { dark-brown } \\
\text { soil+frags }\end{array}$} & \\
\hline & FFM14-15 & $0.25-0.75$ & & hered \\
\hline & FFM16-19 & $0.75-1.75$ & & $\begin{array}{l}\text { hered } \\
\text { it rock }\end{array}$ \\
\hline & FFM20-21 & $1.75-2.25$ & \multicolumn{2}{|c|}{$\begin{array}{l}\text { dark-brown, coarse grained } \\
\text { rock, white/dark brown bands } \\
\text { (ap-mt rock) }\end{array}$} \\
\hline
\end{tabular}

ap-mt: apatite-magnetite rock 


\section{APPENDIX B: LABORATORY TECHNIQUIES}

B-1 : Preparation of samples for XRF and ICP-MS analyses of major, trace and REEs

1. Rock samples were crushed in a Chipmunk jaw crusher and the freshest pieces separated for grinding.

2. Rock and weathered samples were each ground, in a carbon steel shatter box, to approximately 200 mesh. The shatter box has a composition of $\approx 97 \% \mathrm{Fe}, 0.95-$ 1.1\% C, 1.3-1.6\% Cr, 0.25-0.45\% Mn, 0.2-0.35\% Si, $0.025 \% \mathrm{P}$ and $0.025 \% \mathrm{~S}$. To avoid contamination, quartz was ground after each sample and the shatter box thoroughly washed with water and with acetone.

\section{B-2 : Analytical procedures}

\section{XRF}

$1.3 \mathrm{~g}$ of sample was fused together with $4.075 \mathrm{~g} \mathrm{Li}_{3} \mathrm{~B}_{4} \mathrm{O}_{7}$ and $0.85 \mathrm{~g} \mathrm{LiBO}_{2}$, in glass discs. The samples containing high $\mathrm{Fe}$ were diluted by an equal amount of silica $(1.3 \mathrm{~g})$ to meet analytical conditions. The added silica ("SiO${ }_{2}$ FISH"), contains 99.56 wt of $\mathrm{SiO}_{2}$. The actual concentrations for silica in the diluted samples were obtained from the following formula:

$$
\text { [SiO2 analysed - SiO2FISH/2] } \times 2 .
$$

For the rest of the elements, actual wt $f$ oxide concentrations are double the analytical value.

\section{ICP-MS}

$0.1 \mathrm{~g}$ of sample was digested in $\mathrm{HF} / \mathrm{HNO}_{3}$ (+boric and oxalic acids). $\mathrm{HCl} / \mathrm{HNO}_{3}$ was added to the samples which did not dissolve fully in $\mathrm{HF} / \mathrm{HNO}_{3}$. The $\mathrm{Na}_{2} \mathrm{O}_{2}$ sinter procedure was applied to samples which did not dissolve, even after multiple acid attacks.

Analysis of the solution was done using the method of standard addition to correct matrix effects. The standards are prepared and analysed together with the sample. USGS DNC-1 (Diabase) and/or CCRMP MRG-1 (Gabbro) were used as standards for this work. A reagent blank (BLANK) was also prepared and added to the sample.

The detection limits in ppm (LIMIT OF DET - 3 standard deviations) and the reagent blank are normaly $10 \%$ chondrite values. The table below gives the concentrations of trace and REE in the standards and 
reagent blank, and the limits of detection for each analysed element:

Table B-2 : Trace and REEs (ppm) in standard diabase (DNC-1, Govindaraju), gabbro (MRG-1, Govindaraju) and BLANK.

\begin{tabular}{|c|c|c|c|}
\hline LMT & DNC-1 & MRG-1 & BLANK \\
\hline 0.002 & 18 & 14 & 0.204 \\
\hline 0.008 & 41 & 108 & 0.193 \\
\hline 0.022 & 3 & 20 & 0.135 \\
\hline 0.006 & 114 & 61 & 1.083 \\
\hline 0.001 & 3.8 & 9.8 & 0.018 \\
\hline 0.001 & 10.6 & 26 & 0.194 \\
\hline 0.001 & 1.3 & 3.4 & 0.011 \\
\hline 0.012 & 4.9 & 19.2 & 0.012 \\
\hline 0.006 & 1.38 & 4.5 & 0.038 \\
\hline 0.002 & 0.59 & 1.39 & 0.008 \\
\hline 0.006 & 2 & 4 & 0.027 \\
\hline 0.005 & 0.41 & 0.51 & 0.015 \\
\hline 0.001 & 2.7 & 2.9 & 0.015 \\
\hline 0.001 & 0.62 & 0.49 & -0.003 \\
\hline 0.004 & 2 & 1.12 & 0.013 \\
\hline 0.001 & 0.1 & 0.11 & 0.009 \\
\hline 0.006 & 2.01 & 0.6 & 0.042 \\
\hline 0.001 & 0.32 & 0.12 & 0.000 \\
\hline 0.006 & 1.01 & 3.76 & -0.025 \\
\hline 0.007 & 0.089 & 0.8 & 0.014 \\
\hline 0.004 & 0.2 & 0.93 & 0.013 \\
\hline
\end{tabular}


APPENDIX c: Petrography and geochemistry of samples from profile above Panda Hill carbonatite (DH 6)

Table C-1: Petrographic descriptions

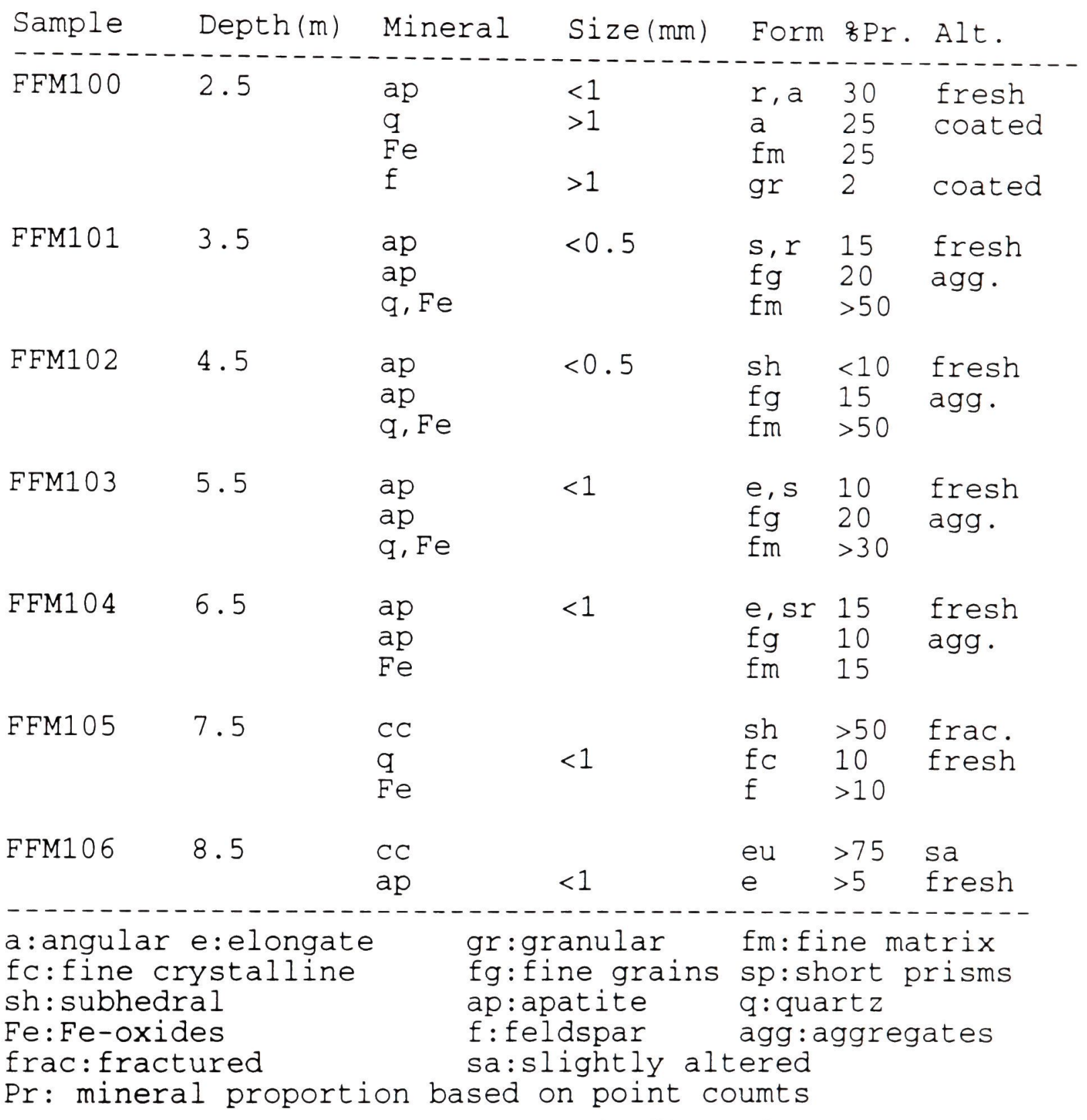

Table C-2: SEM compositions (wt $q$ ) of minerals found in the profile over Panda Hill carbonatite

The analyses varies according to the mineral proportions in the sample. Where the minerals were abundant, analyses reached up to more than 10 for the same thin section. In Table C-2, two or three analyses denote additional analyses of that mineral in the sample. 


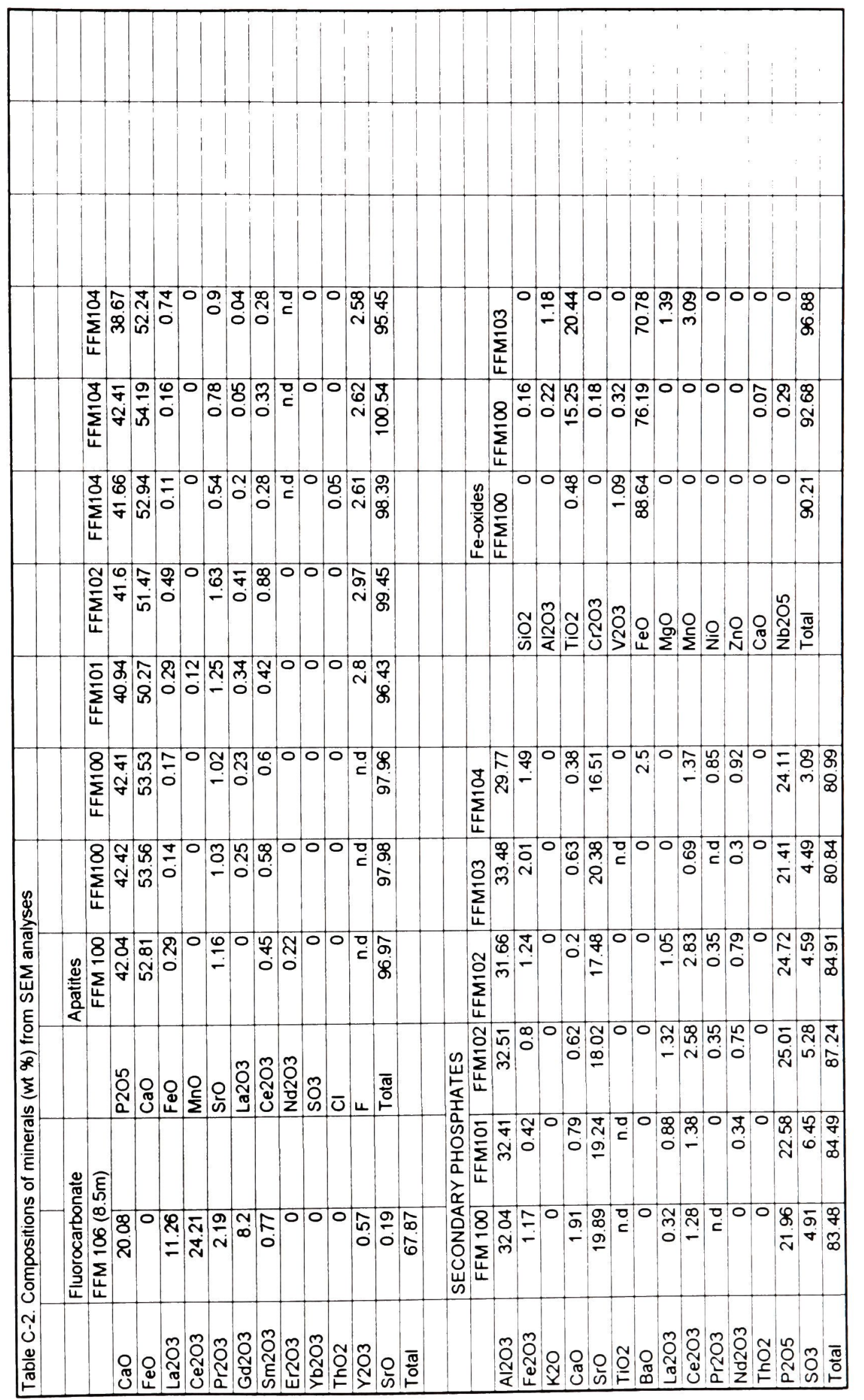


Table C-3: XRD compositions of minerals found in the profile above Panda Hill carbonatite (all from DH6)

\begin{tabular}{|c|c|}
\hline Sample & Minerals \\
\hline FFMIOO & microcline \\
\hline FFM101 & $\begin{array}{l}\text { quartz, goethite, apatite, hematite } \\
\text { ?strengite }\end{array}$ \\
\hline FFM102 & $\begin{array}{l}\text { apatite, kaolinite, goethite, quartz, } \\
\text { jarosites, ?varisite }\end{array}$ \\
\hline FFM103 & apatite, quartz, goethite, boehmite, \\
\hline FFM104 & $\begin{array}{l}\text { apatite, jarosites, quartz, goethite, } \\
\text { hematite }\end{array}$ \\
\hline FFM105 & goethite, quartz, calcite \\
\hline FFM & calcite, apatite \\
\hline
\end{tabular}

Table c-4: REE and trace element concentrations (ppm), in Cl chondrites and primitive mantle respectively (Sun and McDonough, 1989)

$\begin{array}{llllllll}\text { La } & 0.237 & \text { Sm } & 0.153 & \text { DY } & 0.254 & \text { Yb } & 0.170 \\ \text { Ce } & 0.612 & \text { Eu } & 0.058 & \text { Ho } & 0.0566 & \text { Lu } & 0.025 \\ \mathrm{Pr} & 0.095 & \text { Gd } & 0.025 & \text { Er } & 0.1655 & \text { Y } & 1.57 \\ \text { Nd } & 0.467 & \text { Tb } & 0.0374 & \text { Tm } & 0.0255 & & \\ \text { Cs } & 0.0079 & \text { Th } & 0.005 & \text { Ta } & 0.041 & \text { Mo } & 0.063 \\ \text { Rb } & 0.635 & \text { U } & 0.021 & \text { K } & 250 & \text { Sr } & 21.1 \\ \text { Ba } & 6.989 & \text { Nb } & 0.731 & \mathrm{~Pb} & 0.071 & \mathrm{P} & 95 \\ \mathrm{Zr} & 11.2 & \mathrm{Hf} & 0.309 & & & & \end{array}$

